\title{
Molecular prognostic factors in bladder cancer
}

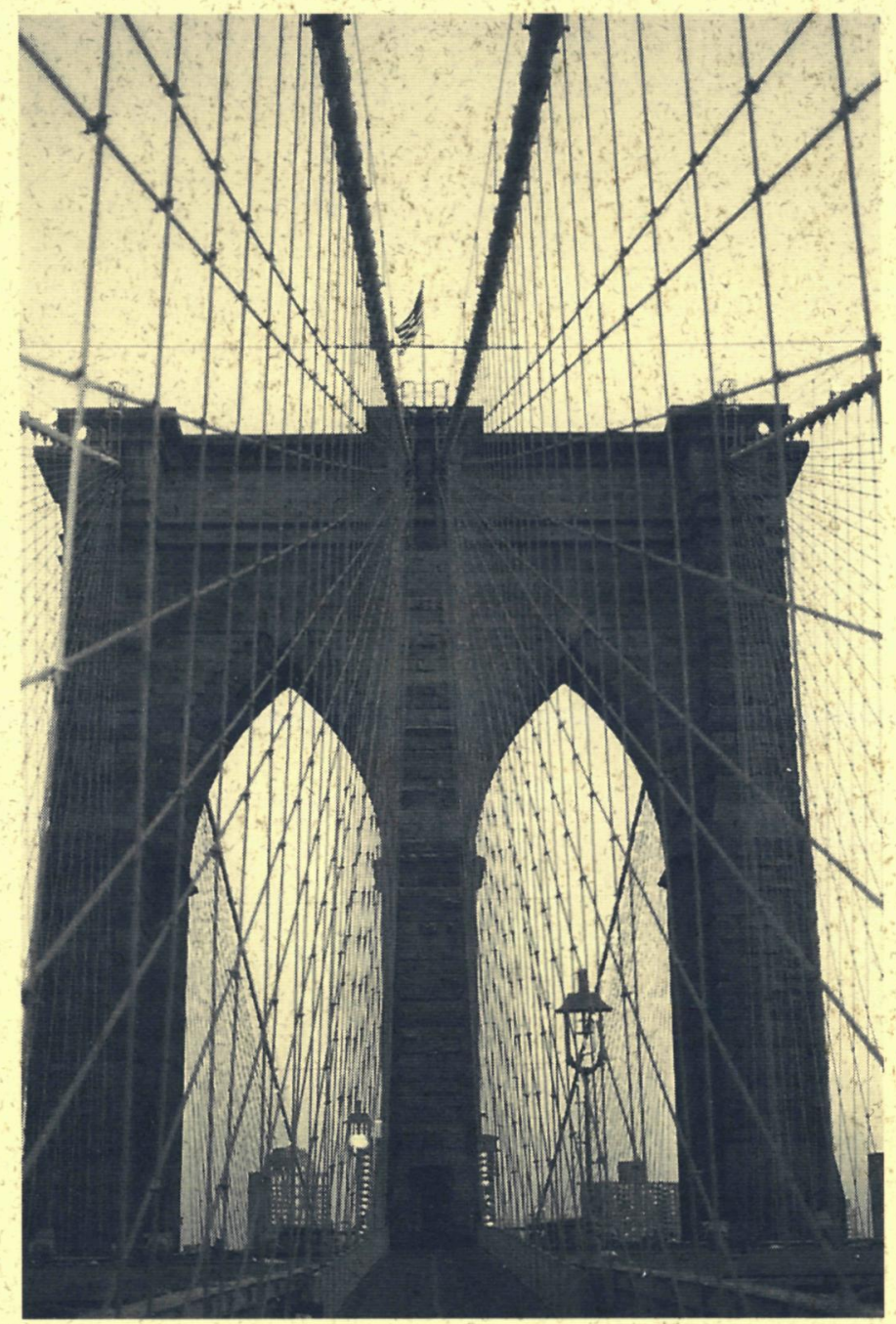

Jacqueline Vet 




\section{Molecular prognostic factors in bladder cancer}

Een wetenschappelijke proeve op het gebied

van de Medische Wetenschappen

\section{Proefschrift}

ter verkrijging van de graad van doctor aan de Katholieke Universiteit Nijmegen, volgens besluit van het College van Decanen in het openbaar te verdedigen op

\section{dinsdag 4 juni 1996}

des namiddags 1.30 uur precies

door 
Promotor

Copromotor

Manuscriptcommıssie
Prof dr F M J Debruyne

Dr J A Schalken

Prof dr $\mathrm{H}$ Bloemers (voorzitter)

Prof dr D J Ruiter

Prof dr A Geurts- van Kessel

The research presented in this thesis was performed at the Urological Research Laboratory, Unuversity Hospital Nıjmegen, The Netherlands

Publication of this thesis was financially supported by the Dutch Cancer Society (KWF)

Prınted by Ponsen \& Looıjen BV, Wagenıngen

Lay-out Salvatore Marras 


\section{Contents}

Chapter 1 Introduction: Molecular basis of bladder cancer development

Implications for molecular prognostic factor studies.

Scope of this thesis

Chapter 2 Comparison of p53 protein overexpression with p53 mutation in bladder cancer: clinical and biological aspects.

Chapter 3 p53 mutations have no additional prognostic value over stage in bladder cancer.

Chapter 4 Predictive value of p53 mutations analyzed in bladder washings for progression of high risk superficial bladder cancer.

Chapter 5 Comparative analysis of p53 mutations in bladder washings and histological specimens.

Chapter 6 Differential expression of ferritin Heavy chain in a rat transitional cell carcinoma progression model.

Chapter 7 Summary and general discussion.

References

Samenvatting en algemene discussie

Dankwoord 
Chapter 1

Introduction

\author{
Molecular basis of bladder cancer development \\ Implications for molecular prognostic factor studies.
}

Part of this chapter was previously published in Molecular prognostıc factors in bladder cancer Jacquelıne A M Vet, Frans M J Debruyne and Jack A Schalken World Journal of Urology $12 \quad 84-891994$ 
In this chapter, the molecular changes relevant for bladder cancer development and progression will be outlined. Furthermore, the prognostic value of these changes will be discussed. Finally, the scope of this thesis is described.

\section{Bladder cancer}

Bladder cancer is the fifth most common cancer in the western male population; for women the incidence is about four times lower (173). In the Netherlands (15 million inhabitants) 3400 new cases of bladder cancer are diagnosed and approximately 1100 patients die each year from this disease (38). Bladder cancer usually presents in the elderly (215) and is strongly correlated with smoking. Indeed, one-half of bladder carcinomas in men and one-third in women are attributable to smoking (85). Other agents associated with bladder cancer include the aromatic amines, aniline dyes, cyclophosphamide, and phenacetin (215).

Transitional cell carcinoma (TCC) is the most common histologic type of bladder cancer, whereas squamous-cell carcinoma, adenocarcinoma, and undifferentiated carcinoma of the bladder account only for a minority of cases. TCC occurs in a wide spectrum of clinical and pathological appearances (204).

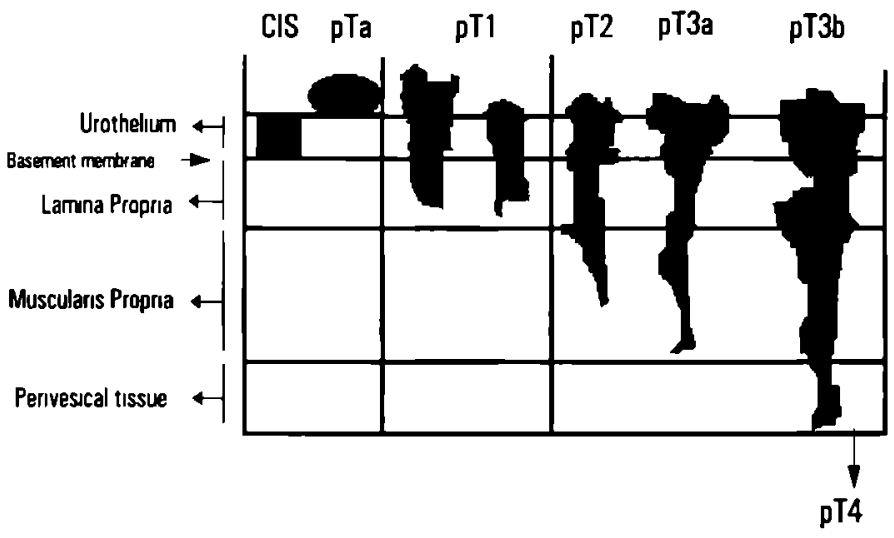

Lymphatic andior vascular penetration

Figure 1. Different histological stages in TCC (36). 
In Figure 1 a schematic drawing of the different histological stages of TCC is shown. About $80 \%$ of bladder tumors will present as superficial TCC, defined as tumor extension restricted to the mucosa (papillary shaped pTa tumors and flat carcinoma in situ (CIS)) or the lamina propria (pT1) of the bladder wall. Muscle-invasive (pT2-pT4) tumors account for $20 \%$ of bladder tumors, usually present de novo and are associated with a worse prognosis and a propensity to metastasize. Most patients with superficial bladder cancer have a good prognosis $(173,226)$. Although 30 to $90 \%$ of the tumors will recur depending on stage, grade, multifocality and treatment modality, only $10-25 \%$ become invasive or metastasize during the course of the disease $(74,101,102)$. The highest recurrence and progression rates are observed in pT1G3 tumors while pTaG3 and pT1G2 tumors show similar rates (108).

A significant problem in the management of patients with superficial TCC is the identification of those patients who are at risk for progression to invasive disease, so that an early change in treatment strategy (conservative to radical) can be made to potentially prevent progression. For invasive bladder cancer, the identification of the metastatic potential of a given tumor is very important because $50 \%$ of patients even if treated with radical cystectomy will die of systemic disease. To address these problems many investigators have tried to identify markers associated with the progression from superficial to invasive or metastatic disease. The recent advances in the molecular approach to tumor biology have revolutionized our knowledge of cancer genetics. Hopefully, a better understanding of the molecular genetic changes involved in bladder cancer progression will provide diagnostic and prognostic information.

\section{Molecular basis of bladder cancer}

\section{Genetic studies}

In general, abnormal DNA content (aneuploidy) is recognized as a marker of malignancy. In bladder cancer, the overall incidence of aneuploidy rises with increasing stage and grade $(29,40,79,219,248)$. Several techniques can be applied to study genetic aberrations during tumor development and progression. DNA content analysis is not able to discriminate between small differences in DNA content, and therefore not suitable to identify specific genetic alterations. Cytogenetic studies revealed an 
association between more specific chromosomal changes and carcinogenesis and disease progression.

Conventional karyotype analyses have shown non random chromosomal changes in bladder cancer involving chromosomes $1,5,7,9$ and $11(3,12,70,71,178,202,231)$. Gibas et al. (71) designated deletion from chromosome 11 as a secondary event in bladder cancer development associated with muscle invasion. Hopman and coworkers performed interphase cytogenetics using centromere-associated probes to study numerical and structural chromosomal changes in non mitotic cells $(88,89,90,168)$. These studies showed chromosome 9 to be under represented as compared to other chromosomes in low stage/low grade TCC, suggesting the loss of this chromosome as one of the primary events in the development of TCC. A new in situ hybridization technique (ISH), comparative genomic hybridization (CGH) allows screening of a tumor genome for chromosomal imbalances (97). The use of CGH to identify DNA alterations in a limited number of TCCs revealed besides known chromosomal losses, distinct amplifications on 1p22, 1q31, 3q24-q26, 8q21, 10p13-14, 12q13-15, 13q21-q34, 17q22$23,18 \mathrm{pl} l$ and $22 \mathrm{q} 11-13(98,239)$.

The technique of Restriction Fragment Length Polymorphism (RFLP) allows an even more detailed analysis of chromosomal changes. The most important allelic losses have been observed on chromosomes 3p (77), 4p (105), 8p (103), 9q and 9p (77,104,221), $11 \mathrm{p}(51,77,221), 13 q(77) ; 17 \mathrm{p}(77,159,221)$ and 18q $(17,105)$. Loss of heterozygosity $(\mathrm{LOH})$ of chromosomes $3 \mathrm{p}, 8 \mathrm{p}, 11 \mathrm{p}, 13 \mathrm{q}, 17 \mathrm{p}$ and $18 \mathrm{q}$ was associated with high stage and high grade tumors. Habuchi and coworkers (77) showed that the loss of chromosome 9q was equally observed in low stage/low grade and high stage/high grade tumors. Furthermore, they found that although the loss of $11 \mathrm{p}$ was more frequently associated with invasive phenotype, the $\mathrm{LOH}$ of $11 \mathrm{p}$ was detected in $35 \%$ of noninvasive tumors. Therefore they concluded that the loss of $11 \mathrm{p}$ might occur at an earlier stage before the loss of $17 p, 13 q$, and $3 p$ in tumor progression. The most important chromosomal changes found in bladder cancer so far are summarized in Figure 2. 


\section{Putative molecular pathways in bladder cancer progression}

Figure 2 also shows the two molecular pathways thought to be involved in bladder cancer progression. Initially, the loss of chromosome 9 was shown to be an early event in bladder cancer progression, whereas the loss of chromosome $17 \mathrm{p}$ occurred at a later stage. The tumor suppressor gene located on $17 \mathrm{pl} 3.1$ is p53 (11) and mutations in the p53 gene were associated with high stage tumors (199). It was suggested that loss of chromosome 9 may cause proliferative behavior and that p 53 mutations were necessary to intiate progression to invasive disease. However, it has recently been shown that in $65 \%$ of CIS, the p53 gene is mutated, whereas chromosome 9 deletions occur significantly less frequent than in invasive tumors $(146,207)$. These results suggest the existence of a second molecular progression pathway to invasive disease, whereby the p53 mutation is the initial event and chromosome 9 loss occurs later.

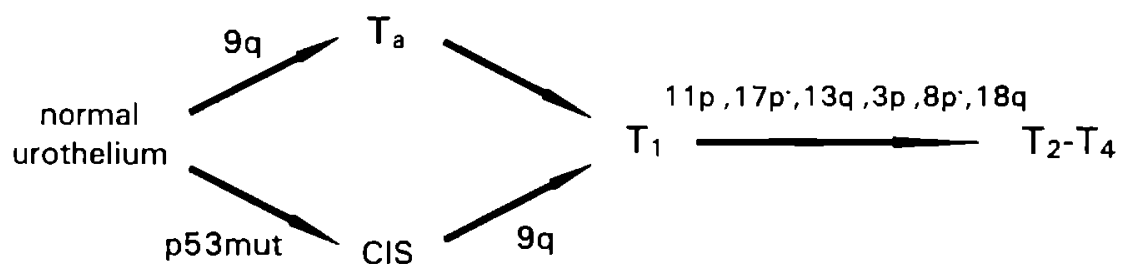

Figure 2. The two putative molecular pathways in bladder cancer progression.

\section{Candidate oncogenes and tumor suppressor genes}

Many of the regions involved in allelic loss are likely to harbor tumor suppressor genes, whereas the chromosomal amplifications could indicate the presence of protooncogenes. Table 1 summarizes the chromosomal regions that may harbor genes involved in bladder cancer development or progression. The gene for the retinoic acid receptor is located on chromosome $3 p$ and it is of interest since the loss of this receptor is correlated with a poor prognosis in bladder cancer $(37,138)$. The von Hippel-Lindau (VIIL) disease tumor suppressor gene is also located on chromosome $3 p$ but its relevance for bladder cancer is not yet determined (113). DNA polymerase $\beta$ is an interesting candidate gene which maps within the region of deletion on 8p21-8q11.2 that 
might have an effect on the mutation rate (105). At least two tumor suppressor genes are likely to be mapped on chromosome $9(100,161,175)$. Region 9 p21-22 is of particular interest because two studies independently reported homozygous deletions in this region $(23,41)$. The CDKN2 (MTS1) gene is located at 9p21, its product, p16, inhibits the cyclinD/cdk4 complex that phosphorylates pRB, thus negatively regulating cell cycle progression (193). The deleted area on chromosome $11 \mathrm{p}$ contains the ras oncogene (165), the two Wilms' tumor suppressor loci (WT1 and WT2, at $11 \mathrm{p} 13$ and $11 \mathrm{p} 15$, respectively) $(25,107)$ and the CAT locus, that is thought to be involved in DNA repair processes (197). The retinoblastoma gene, the first identified tumor suppressor gene, is the candidate gene on $13 q 14$ (206). As addressed earlier chromosome 17p harbors the tumor suppressor gene p53. The DCC gene (18q21), known to be involved in colorectal cancer (52), might be the target of deletions in a subset of bladder tumors.

Table 1. Chromosomal deletions in bladder cancer and candidate oncogenes and tumor suppressor genes.

\begin{tabular}{ll}
\hline Locus & Candidate gene \\
\hline $3 p$ & retinolc acid receptor, VHL \\
$8 p 21-8 q 11.2$ & DNA polymerase B \\
$9 p 21-22$ & CDKN2 \\
$11 p$ & H-ras; WT1 (11p13); WT2 (11p15); CAT locus \\
$13 q 14$ & RB \\
$17 p 13.1$ & p53 \\
$18 q 21$ & DCC \\
\hline
\end{tabular}

The exact biological role of these chromosomal aberrations and the genes involved is subject for on-going investigations and once these genes are identified, a more complete view of the genetic events that determine progression will be possible.

\section{Differential gene expression}

Another approach in the search for new molecular markers with prognostic value is to compare different stages of progression at the level of gene expression by means of differential or substraction hybridization analysis of cDNA libraries. These methods are 
based on comparison of steady state mRNA populations. A drawback of these techniques is that genes that are aberrantly expressed (i.e. different size of transcript) can not be identified, unless the level of steady state mRNA has changed. Differences in post-translational regulation cannot be identified using this approach. However, the advantages of differential/substraction hybridization analyses are, that relevant but unknown genes can be isolated. Moreover, genes that are either upregulated (e.g. oncogenes) or down modulated (e.g. tumor suppressor genes) can be identified. The cDNA clones identified can be routinely characterized by DNA sequence analysis and comparison of the resulting DNA sequence with nucleotide sequence data bases. If the isolated cDNA clone is of interest it can be immediately evaluated for its use in diagnosis by RNA in situ hybridization analysis (211). The selection of the method for comparing mRNA populations depends on the relative abundance of the mRNA population of interest. To study high and low abundance transcripts $(>0.01 \%)$, the differential hybridization analysis is a valid approach $(180,189)$. The identification of very low abundance $(<0.01 \%)$ differentially expressed genes, requires a more sophisticated approach, i.e. substraction hybridization analysis which is based on the substraction of common mRNAs from a given population, thus leaving unique mRNAs (at very low levels, $0.001 \%$ ) (218). Both differential and substraction hybridization are technically difficult and require relative large amounts of approx. $5 \mu \mathrm{g}$ poly- $\mathrm{A}^{+}$RNA. A recently developed alternative approach, named mRNA differential display offers the important advantages that much less mRNA (approx. $10 \mathrm{ng} /$ reaction) is required. Furthermore, it is quicker and technically simpler $(120,121,122)$. The most essential part of these three "gene-hunting" techniques is the choice of the mRNA populations that are compared which should be homogeneous and well characterized. At present the above mentioned techniques have succeeded in isolating only a small number of important genes, i.e., NM23 (208), stromelysin-3 (8), EMSI (191) and WAF-1 (45), which were all identified in very precisely defined populations.

In the following paragraphs the value of the most relevant known molecular prognostic markers for bladder cancer will be discussed. 


\section{Molecular prognostic factors}

\section{DNA ploidy}

By DNA flow cytometry or image cytometry insight can be obtained in the extent of genetic damage. In a few studies the biological significance of aneuploidy in tumor progression has been addressed. It has been hypothesized that tumor cells first acquire a tetraploid status, whereafter cells can evolve by chromosome loss without lethal effect $(42,69)$. Thus, more aggressive clones could emerge at a higher rate in these tumors than in diploid tumors. Aneuploidy in bladder tumors has been extensively studied and correlates with a high propensity to progress to invasion and metastasis as well as with poor survival $(14,106)$. In muscle invasive operable bladder cancer, DNA ploidy does not represent a prognostic parameter (58). For superficial bladder cancer (Ta/T1) the 2c deviation index appeared to have significant predictive value for survival $(15,190)$ However, the DNA content may be a differential prognostic marker only for grade 2 tumors, since most grade 1 tumors are diploid and most grade 3 tumors are aneuploid.

\section{Epidermal Growth Factor Receptor}

The interest in studying Epidermal Growth Factor (EGF) and its receptor (EGFR) was based on the finding of high EGF (urogastron) levels in urine. Messing et al. reported in 1984 that growth and division of certain TCC cell lines responded to EGF (140). Several investigators have studied the epidermal growth factor receptor (EGFR), the product of c-erbB-1 (located on chromosome 7), and found a significant correlation between EGFR overexpression and both grade and stage $(13,141,153,174)$. The correlation between EGFR positivity and clinical outcome was studied immunohistochemically in 101 bladder tumors $(125,154,155)$. EGFR overexpression appeared to be a significant prognostic factor for the whole group studied. The difference in survival between EGFR-positive tumor and EGFR-negative tumor bearing patients was not significant when the data from patients with muscle invasive disease were analyzed separately. However, in patients with superficial TCC (pTa, pT1), EGFR overexpression is correlated with recurrence rate, time to recurrence and tumor progression.

EGFR gene amplification has been studied by Southern blot analysis but was found in only one out of 31 bladder tumors (13). When the polymerase chain reaction was used to 
assess EGFR amplification in carcinoma cells from bladder washings, an amplification in 2 out of 47 patients was observed (131). A more recent study showed the same rate of EGFR gene amplification (5 out of 107 tumors) (187). Apparently, EGFR gene amplification is not a predominant mechanism for EGFR overexpression.

EGFR expression can be induced by overexpression of the H-ras gene. This was found to occur both at the protein and mRNA levels and analysis of EGFR promotor/enhancer sequences has revealed a putative AP-1 site which may possibly serve as a ras responsive element (212). These results suggest a role for overexpression of H-ras, whether wild type or mutant, in upregulating the EGFR. Mutated H-ras in bladder cancer has been reported at various frequencies ranging from $6 \%-44 \%$ in different studies, but no correlation with grade or stage was observed $(20,35,57,104,116)$. This range in mutation frequencies could be caused by the use of different detection methods and variable tumor specimens. The exact role of $\mathrm{H}$-ras in bladder cancer remains to be elucidated.

In conclusion, overexpression of EGFR might be useful as a prognostic marker in the group of superficial bladder tumors.

\section{C-erbB-2}

C-erbB-2 is a human proto-oncogene located on chromosome $17 \mathrm{q} 21$ encoding a transmembrane growth factor receptor with significant sequence homology to the EGFR (252). Different studies showed varying rates of c-erbB-2 gene amplification ranging from $8 \%-46 \%$. C-erbB-2 protein overexpression was shown to be more frequent than the gene amplifications $(32,186,256)$. Hence, for c-erbB-2 overexpression, gene amplification also does not seem to be the predominant mechanism. Moreover, Underwood and coworkers (227) concluded that c-erbB-2 gene amplification was of no value as an independent marker for the prediction of disease recurrence or progression.

Sato et al. (185) showed c-erbB-2 protein expression to be correlated with tumor grade and survival. Multivariate analysis showed that c-erbB-2 expression was a prognostic factor independent of grade and stage of the tumors. In contrast to the findings of other recent immunohistochemical studies (114,125,227). Although the study of Lipponen (125) showed a correlation between c-erbB-2 expression, grade, DNA aneuploidy, high S-phase fraction and decreased survival, no additional significant prognostic value over 
already established prognostic parameters in TCC was found. In the other two studies no significant correlation with either grade, stage or survival was observed.

At present it appears that c-erbB-2 gene amplification and protein overexpression have no additional predictive value for disease recurrence or progression. The disparity between the different immunohistochemical studies emphasizes the need for further detailed investigation.

\section{The Retinoblastoma gene}

Another tumor suppressor gene potentially involved in bladder cancer is the Retinoblastoma $(\mathrm{RB})$ gene located on 13q14. Restoring the wild-type RB function in a RB-negative cell line (HTB9) resulted in complete suppression of growth in soft agar and decreased tumorigenicity in nude mice, suggesting a key role for the RB gene in bladder cancer (209). The RB gene encodes a nuclear phosphoprotein and several investigators have hypothesized that it functions as a cell cycle control protein $(72,115$, 244). More recently, it has been suggested that pRB functions downstream of $p 53$ in the same regulatory pathway. HPV proteins E6 that targets p53 for destruction and E7 that binds to $\mathrm{pRB}$, undermine the p53-pRB-dependent damage checkpoint (39,201). p53 influences the activity of cyclin-dependent kinases that phosphorylate $p R B$, via $p 21$ production (45). High levels of p21 inhibit cyclinE-Cdk2, which usually phosphorylates $\mathrm{pRB}$ in G1/S of the cell cycle, thereby resulting in hypo-phosphorylated $\mathrm{pRB}$. This form of $\mathrm{pRB}$ blocks the transcription of genes required for subsequent stages of the cell cycle and arrests the cell cycle.

Loss of RB function at the protein level occurs in approximately one-third of human bladder cell lines (92). Gross structural deletions of the RB gene as well as point mutations have been documented in many of these cell lines $(91,92)$. More recently, loss of RB protein expression and deletions at the RB locus have been identified in primary bladder cancers, and it appeared that altered $\mathrm{RB}$ expression is correlated with high grade and high stage tumors $(22,33,68,73,95,128,130,251)$. A strong correlation was found between $\mathrm{LOH}$ at the $\mathrm{RB}$ locus and the absence of normal RB protein expression (251). $\mathrm{Rb}$ gene mutations have been shown to occur in both low grade superficial as in high grade invasive bladder cancers (145). Two immunohistochemical studies have shown that a decreased expression of the $\mathrm{RB}$ protein is associated with a more aggressive 
biological behavior $(33,130)$. Decreased $\mathrm{Rb}$ expression correlated with shortened survival in the group with invasive tumors. Based on current knowledge it can be concluded that altered $\mathrm{RB}$ protein expression may be a prognostic marker in patients with invasive bladder cancer.

\section{E-Cadherin}

To metastasize, cancer cells must be released into the blood or lymphatic stream. Decreased intercellular adhesiveness favors detachment of tumor cells and may play a role in the early steps of the metastatic process. Although cell-cell adhesion is complex involving at least four families of adhesion molecules (integrin, immunoglobulin, selectin, and cadherin), several lines of evidence indicate that the $\mathrm{Ca}^{2+}$-dependent, $\mathrm{E}$ cadherin-mediated adhesiveness is critically important for epithelial integrity (210). Modulation of E-cadherin function of several tumor cell lines either by blocking antibodies or by transfection experiments revealed an invasion suppressor role for $\mathrm{E}$ cadherin-mediated cell-cell adhesion in vitro $(10,63,235)$. The correlation between $\mathrm{E}$ cadherin expression and in vitro invasiveness has been tested for 3 bladder cell lines. The RT4 and RT112 cell lines express E-cadherin and are not invasive, whereas the EJ24 cell line does not express E-cadherin and is invasive (63). E-cadherin expression has been analyzed in 49 bladder tumors with anti-E-cadherin monoclonal antibodies (18). In this immunohistochemical study decreased E-cadherin expression correlated with both increased grade and stage whereas abnormal E-cadherin expression correlated with shorter survival for the whole group studied as well as for the group with invasive tumors. No conclusions can be drawn for the patients with superficial TCC. These data were recently confirmed by Otto et al. (162) who also observed a concomitant association between increased overexpression of the autocrine motility factor and progression of disease. In conclusion, E-cadherin seems to have potential as a prognostic marker although its precise clinical relevance has to be assessed in larger clinical trials. 


\section{Potential prognostic factors}

Besides the most relevant prognostic parameters, there is an additional panel of molecular factors with potential prognostic relevance but only the most important parameters will be discussed.

Scatter factor (SF) has been shown to be overproduced by bladder carcinomas (96) and is involved in invasion and angiogenesis. Both are characteristics of biologically aggressive tumors suggesting that the accumulation of SF within tumors might promote progression to a more malignant phenotype. Its exact clinical relevance remains to be determined. Fradet and coworkers raised monoclonal antibodies against tumor-associated antigens $(59,60,61)$. The most relevant ones are the tumor-associated antigens M344 and T138. M344 is predominantly expressed on superficial TCC and its expression decreases with increasing grade of the tumors (62). Preliminary data suggest that M344 positive tumors rarely progress. T138 was found to have an independent significant prognostic value for bladder cancer (174). Larger clinical studies, in which also the separate groups of superficial and invasive tumors are studied, are necessary to reveal the exact clinical usefulness of T138.

Altered expression of MDM2 is reported in bladder cancer $(78,119)$ and overexpression is associated with low grade, low stage bladder tumors and has been implicated in the progression of bladder cancer. Whether MDM2 overexpression represents an alternative to $\mathrm{p} 53$ mutation in inactivating the $\mathrm{p} 53$ regulatory pathway is still unclear.

\section{The p53 tumor suppressor gene}

\section{The p53 gene}

The most extensively studied tumor suppressor gene is p53, often referred to as "the guardian of the genome" (111). Since the main part of the present thesis concerns the value of p53 as a prognostic marker in bladder cancer, p53 will be discussed more extensively.

The p53 gene is located on chromosome $17 \mathrm{p} 13.1$ (11) and it is mutated in over half of all human tumors (87). Frequently one of the two alleles is lost and the other is mutated $(6,87)$. Most mutations are found in four conserved domains (II: aa 117-142; III: aa 171181; III: aa 234-258; IV: aa 270-286), located in the DNA binding domain of the p53 
protein (205). The protein encoded by the p53 gene is a 53-kd nuclear phosphoprotein consisting of a transactivation-, a DNA binding- and an oligomerization domain (Figure $3)$.

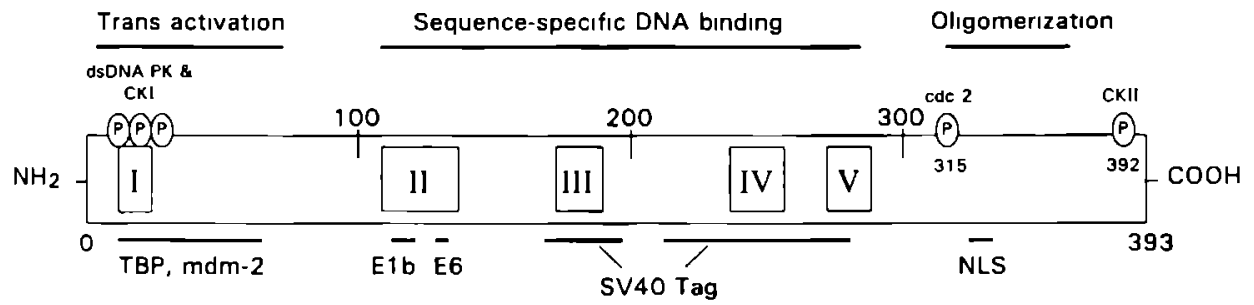

Figure 3. Structural domains of human p53. Boxes II to $V$ represent the conserved regions containing the frequent sites of mutation. Above the p53 sequence the different domains of p53 activity and the positions of defined phosphorylation are indicated. Below the $p 53$ sequence, the main nuclear localization signal (NLS) and the interaction of various factors with p53 are shown. Abbreviatıons: dsDNA-PK, double-stranded proteın kınase; CKI, caseın kınase I; cdc-2, p34 ${ }^{\text {cdc2 }}$ kınase; CKII, caseın kınase II; TBP, TATA bındıng proteın; mdm-2, murıne double mınute-2; E1b, adenovirus 5 E1b proteın; E6, human papılloma virus E6 proteın, SV40 Tag, sımıan virus 40 large T antıgen; NLS, nuclear localızation signal (adapted from: Harris et al. (84); Prives et al. (170)).

\section{Transcriptional regulation by $\mathbf{p 5 3}$}

The tumor suppressor protein p53 plays a role as a transcriptional regulator $(49,99,129$, $166,238,253$ ) and is involved in the control of the cell cycle at $\mathrm{G} 1$ to $\mathrm{S}$ phase transition $(54,134)$. When DNA is damaged, p53 can delay the progression through the cell cycle allowing DNA repair (134) or can inttiate programmed cell death (apoptosis) (132). It should be stressed that p 53 is more involved in regulatıng and controlling the cell cycle, than in playing a direct mechanistic role in cell cycle progression. Studies using knockout mice have demonstrated that functional p53 is not essential for mitotic or meiotic cell cycles, but the high incidence of tumor development in p53-null mice (43) strongly suggests that p53 provides an important checkpoint that prevents aberrant growth, division and neoplastic transformation. Loss of wild type p53 function results in an altered Gl-S cell cycle checkpoint which can lead to replication of incorrect DNA, resulting in genetic instability (129,253). 
p53 acts both through transcriptional suppression and transcriptional activation. The p53 protein interacts with the transcription factors $\operatorname{Taf}_{\mathrm{II}} 40$ and $\operatorname{Taf}_{\mathrm{II}} 60(216)$ and possibly also with the TATA binding protein (TBP) $(28,195,220)$. These interactions are thought to contribute to the ability of $\mathrm{p} 53$ to repress general transcription. p53 can activate transcription by binding to repeats of the DNA consensus site PG (44). Viral oncogenes that overcome p53-mediated growth suppression abrogate its ability to transactivate (142). A few targets of p53 transcriptional activation have been identified that might account for the G1 arrest in response to DNA damage (Figure 4).

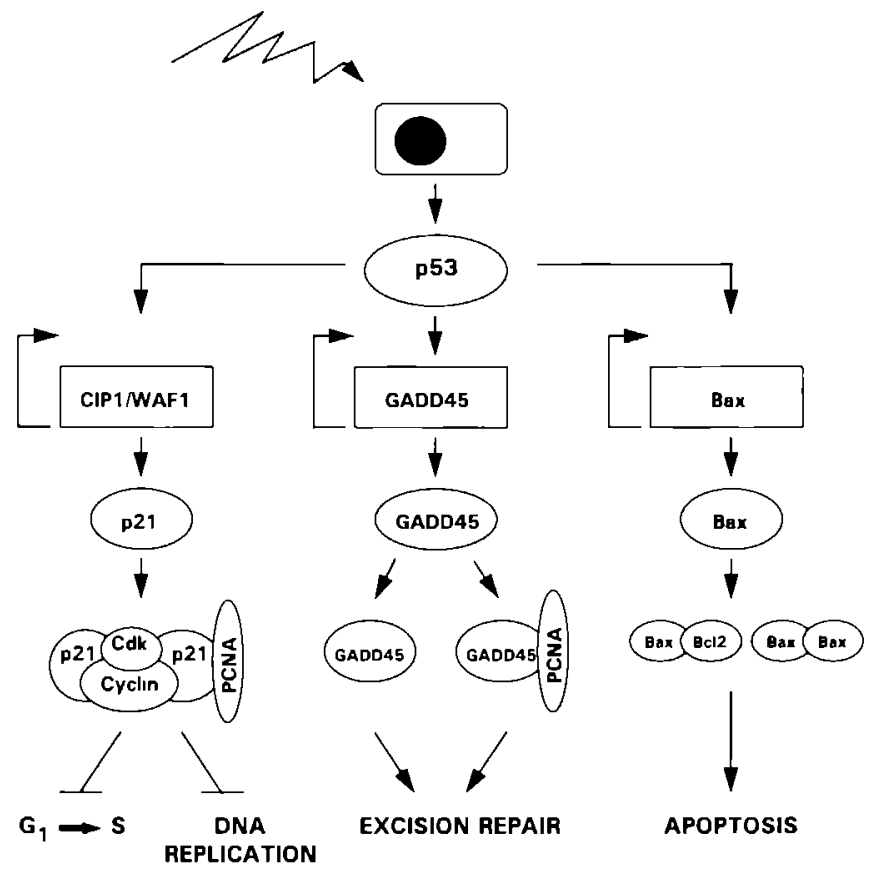

Figure 4. The p53 mediated response to DNA damage (177). 


\section{The p53 mediated responses to DNA damage}

\section{DNA repair}

WAF-1 (wild-type p53 activated fragment), also known as CIP1 (83) and Sdi (156), was isolated by substractive hybridization screening from cells overexpressing p53 (45). The protein p21 encoded by WAF-1 is an inhibitor of G1 cyclin dependent kinases and complexes with cyclin, $\mathrm{Cdk}$ and PCNA (proliferating cell nuclear antigen) in normal cycling cells (250). The p21 protein is known to interact directly with PCNA thereby blocking its replication, but not its repair activity $(118,198,240,242)$. Although upregulation of $\mathrm{p} 21$ by $\mathrm{p} 53$ appears to be the most important mediator of p53 mediated growth arrest, other genes that are transcriptionally activated by p 53 may also play a role in DNA damage-dependent cell cycle arrest.

For example, cyclin G1, a gene, whose expression is induced by wild-type p53 (157), might be a candidate although its exact role in cell cycle arrest or apoptosis is not clear (21). The excision repair ERCC3 gene may also be transcriptionally induced by p53 (241). Smith and coworkers showed that GADD45 (growth arrest and DNA damage gene) which is also upregulated by $\mathrm{p} 53$, probably serves as a link between the p53dependent cell cycle checkpoint and DNA repair (203) (Figure 4). GADD45 can interact directly with the essential replication factor PCNA (203), thereby blocking DNA replication and possibly enhances nucleotide excision repair of damaged DNA.

\section{Apoptosis}

The responses mentioned above presumably favor enhanced survival. However, in some situations, p53 activates a suicide pathway (apoptosis) following DNA damage. Recently, Miyashita and Reed (147) suggested a mechanism by which p53 might induce apoptosis. Bax and $\mathrm{Bcl}-2$ are homologous proteins that have opposing effects on apoptosis (Figure 4). Bcl-2, the product of a proto-oncogene, protects the cell from apoptosis, while Bax acts as an apoptotic signal (158). The upregulation of p53 in some cell types is concomitant with the down-regulation of $\mathrm{Bcl}-2$, and the upregulation of Bax. The induction of the Bax protein increases the concentration of Bax:Bax homodimers and Bax:Bcl-2 heterodimers in the cell, thereby potentiating apoptosis under certain circumstances (158). Recent evidence indicates that a functional p53 
pathway is required for efficient cell kill by chemotherapeutic agents $(56,133)$, although conflicting findings have also been reported $(16,65)$.

The p53 protein controls the maintenance of DNA integrity by the mechanisms mentioned above. In addition to mutation, loss of wild type p53 function can be the result of complexation with viral oncoproteins, e.g., simian virus 40 (SV40) Large T antigen (110,124), adenovirus 5 E1b (184) and E6 protein of human Papillomavirus 16 and 18 (243). The cellular oncoprotein, $\mathrm{mdm} 2$ also interacts directly with p53 and functionally inactivates it (148).

\section{Prognostic value of p53}

The p53 tumor suppressor gene can be studied directly by analyzing p53 gene mutations using e.g. Single Strand Conformation Polymorphism (SSCP) or direct sequencing. The occurrence of p53 mutations can lead to conformational changes of the p53 protein, resulting in a prolonged half-life and subsequently, in accumulation of the protein (55). The extended half-life of the protein is the basis for immunohistochemical detection of p53. Despite the good concordance between p53 mutation and p53 overexpression, discrepancies are observed in a substantial number of tumors. $(34,46,214$; this thesis).

A number of studies have investigated p53 genetic alterations in bladder cancer. The loss of heterozygosity of chromosome $17 \mathrm{p}$ is associated with high grade and high stage bladder carcinomas (159). By means of subcloning and sequencing of exon 5 through 9 of the p53 gene, it has been shown that $17 \mathrm{p}$ allelic loss is strongly associated with $\mathrm{p} 53$ mutation in 9 out of 10 cases and that p53 mutation is associated with high stage tumors (199). The correlation between p53 mutations and stage as well as grade was confirmed in four other studies using PCR-SSCP (64,207,245; this thesis). Analysis of p53 mutations in carcinoma in situ showed a high prevalence of $65 \%$ of p53 mutations similar to that seen in invasive bladder cancer $(146,207)$ (see Figure 2).

The relatively high frequency of p53 mutations in T2-T4 tumors compared to T1 tumors suggest their involvement in the progression of $\mathrm{T} 1$ tumors to invasive disease (207). However, the exact point at which p 53 mutations occur during tumor progression from Ta to $\mathrm{Tl}$ and T2-T4 tumors is still unclear. p53 mutations were reported to have prognostic significance for bladder cancer (225; this thesis), although it offered no additional prognostic value over stage for invasive bladder cancer (T2-T4) (this thesis). 
The exact prognostic value of p53 mutations for superficial bladder cancer remains to be determined.

Overexpression of the p53 protein has been reported to have a clear prognostic significance for superficial bladder cancer $(47,181,182,194)$, although conflicting data were also reported $(66,125)$. Differences in antibody, methodology, treatment of the patients and the scoring systems used might explain these differences. The prognostic value of p53 overexpression is also ambiguous for invasive tumors $(47,125,183$; this thesis). Apparently, as long as the tumors are confined to the bladder ( $\mathrm{pT} \leq 3 \mathrm{~A}$, confined to the detrusor muscle), p53 immunohistochemistry has prognostic value. With more extensive disease, p53 alterations have no additional prognostic value. 


\section{Scope of this thesis}

In this thesis two approaches are used to investıgate the predictive value of molecular markers for bladder cancer progression

First, the prognostıc value of a known gene, the tumor suppressor gene p53, was studied Alterations of p53 can be studied by various methods In chapter 2, the direct detection of mutations in the p53 gene by PCR-SSCP and the immunohistochemical detection of p53 protein overexpression were compared to assess their usefulness To evaluate the prognostic value of p53 alterations in bladder cancer, we studied the association of both p53 overexpression (Chapter 2) and p53 mutations (Chapter 3) with grade, stage and survival Furthermore, the association of p53 mutations with frequency of allelic loss as a putative indicator of genetic instability, was investigated To assess the value of p53 mutations (PCR-SSCP) in predicting the progression of superficial TCC, consecutive bladder washıngs from high risk superficial TCC patients (indicated by quantitative karyometric analysıs) were examıned (Chapter 4) To determıne the actual value of bladder washing specimens to assess the p53 status of histological specimens we analyzed the bladder washings and their synchronous tumors for the presence of p53 mutations (Chapter 5)

As a second approach we used differential hybridization analysis to identıfy new molecular prognostic markers We used a rat bladder tumor model system (RBT), in which the different stages of tumor progression are represented In the differential hybridization analysis the mRNA populations of low and high metastatic lines were compared (Chapter 6) 


\title{
Chapter 2
}

\section{Comparison of $\mathrm{p} 53$ protein overexpression with p53 mutation in bladder cancer: Clinical and biological aspects.}

Jacquelıne A M Vet ${ }^{1}$, Pierre Paul Bnnguier ${ }^{1}, \mathrm{H}$ Ewout Schaafsma ${ }^{2}, \mathrm{~J}$ Alfred Witjes ${ }^{1}$, Frans M J Debruyne' and Jack A Schalken'

\begin{abstract}
BACKGROUND Alterations of the tumor suppressor gene p53 are known to occur in bladder cancer Although p53 overexpression is associated with mutation of the p53 gene, a substantial discrepancy between molecular genetic alteration in p53 and overexpression of the protein has been found

EXPERIMENTAL DESIGN Tumor specimens of 39 bladder cancer patients were immunohistochemically analyzed for $\mathrm{p} 53$ overexpression, and the results were compared with the presence of a mutation as assessed by Single Strand Conformation Polymorphism (SSCP) and direct sequencing Both clinical and biologic aspects were studied

RESULTS A significant correlation between p53 overexpression and poor survival in the whole group studied was found $(p<001)$ No association between $p 53$ overexpression and decreased survival was found for invasive tumors in contrast with other studies Differences in treatment of the patients and different antibodies and scoring systems used might explain these differences In our study, the Kaplan Meier curves showed the same result for p53 overexpression and p53 mutation when the whole group and the invasive tumors were studied However, in the group of superficial tumors, which was unfortunately too small for statistical dnalysis, we found $\mathrm{p} 53$ overexpression in three tumors while no 533 mutations were found A good concordance between $p 53$ mutation and $p 53$ overexpression was found $(p<002)$ However, two out of eight tumors with an SSCP proven p53 mutation showed no p53 immunoreactivity, probably as a result of loss of the nuclear localization signal Twenty three percent $(7 / 31)$ of the tumors showed p53 overexpression without any sign of a mutation

CONCLUSION Our results indicate that, despite a good concordance between p53 mutation and p53 overexpression, there is no direct causal relationship between mutation and protein accumulation Apparently other events than mutation can trigger p 53 stability
\end{abstract}

Department of Urology', University Hospital Nımegen and the Department of Pathology ${ }^{2}$, Canisius Wilhelmina Hospital, Nijmegen, The Netherlands This study was supported by the Dutch cancer foundation, NUKC9102 (J A M V ) and FUSEX (P P B ) Published in Lab Invest 73 (6) $837-8431995$ 


\section{Introduction}

The tumor suppressor gene p53 is located on chromosome $17 \mathrm{p} 13.1$ and encodes a $53 \mathrm{kD}$ nuclear phosphoprotein with specific DNA binding properties. Chromosomal losses of 17 p13 occur during tumor progression in a variety of human tumors (87). In bladder cancer, loss of $17 \mathrm{pl3}$ is associated with high grade tumors and invasive disease $(159,169)$. In accordance with the classic tumor suppressor theory, the loss of heterozygosity $(\mathrm{LOH})$ of $17 \mathrm{pl} 3$ is often accompanied by a mutation of the remaining allele (6). In bladder cancer, p53 mutations correlate with grade and stage $(64,199,233)$ and probably play a role in the progression of this disease.

Wild-type p53 acts as a cell cycle control protein at the level of G1 to $S$ phase transition (99). If DNA damage occurs, p53 levels rise and block cells in the G1 phase. The DNA damage can subsequently be eliminated either by DNA repair or by initiation of apoptosis (132). The up-regulation by $\mathrm{p} 53$ of p 21 , an inhibitor of G1 cyclin-dependent kinases, appears to be responsible for p53 mediated growth arrest (94). Recently, Smith et al. showed that Gadd45 which is upregulated by p53, probably serves as a link between the p53-dependent cell cycle checkpoint and DNA repair (203). p53 seems to function through modulation of transcriptional activity, enhancing the expression of genes containing p53-binding sites and interacting with a variety of transcription factors to inhibit the expression of other genes $(166,254)$. Cells that lose this wild type p53 function fail to show growth arrest if DNA damage occurs which can lead to replication of incorrect DNA, resulting in genetic instability $(129,253)$.

In addition to mutation, loss of wild type p53 function can be the result of complexing with viral oncoproteins, e.g., simian virus 40 (SV 40) large T Ag (110,124), adenovirus 5 Elb protein (184) and E6 protein of human Papillomavirus 16 and 18 (243). The cellular oncoprotein $\mathrm{mdm} 2$ also interacts directly with p 53 and functionally inactivates it (148).

The occurrence of p53 mutations leads to conformational changes of the protein, resulting in a prolonged half-life and subsequently in accumulation of the protein (55). The extended half-life of the protein is the basis for immunohistochemical detection of p53. Although there is a good concordance between p53 overexpression and mutation of the p53 gene, several studies have shown a considerable discrepancy between molecular genetic alteration in $\mathrm{p} 53$ and overexpression of the protein $(26,81,137,249)$. 
In this study we compared the immunohistochemical detection of $\mathrm{p} 53$ overexpression with p53 mutation as assessed by Single Strand Conformation Polymorphism (SSCP).

\section{Materials and methods}

\section{Tumor specimens}

Twenty-three snap frozen, superficial bladder carcinomas (pTa-pTl) and 24 muscleinvasive bladder carcinomas ( $\mathrm{pT} \geq 2$ ) obtained from 45 patients were used for SSCP analysis, as described previously (233). The transitional cell carcinomas were classified according to the World Health Organisation criteria (149). For immunohistochemistry the same specimens were investigated with the exception of 2 superficial and 2 invasive carcinomas that could not be analyzed because of poor quality of the frozen tissue. Moreover, the two squamous cell carcinomas were removed from this study because of their different pathologic background. The clinical and pathologic data are shown in Table 1. Genomic DNA was extracted from step-sectioned tumors ( $>70 \%$ tumor cells) using a method described by Miller and coworkers (144).

\section{Immunohistochemistry}

Cryostat sections $(5 \mu \mathrm{m})$ were dried overnight. Tissue sections were fixed in acetone for 10 minutes and then incubated overnight at $4^{\circ} \mathrm{C}$ with the mouse mAb DO-7 (Novocastra, Newcastle upon Tyne, UK) at a dilution of $1: 100$. This Ab recognizes both wild-type and mutant p53. Sections were subsequently incubated for 30 minutes with biotinylated sheep anti-mouse Ig antibody (1:200, Amersham, Buckinghamshire, UK) and then incubated for 30 minutes with streptavidin biotinylated-horseradish peroxidase complex (1:100, Amersham). After washing with PBS, 3,3'- Diaminobenzidine (Sigma Chemical Company, St. Louis, MO, USA) was used as a chromogen and hematoxylin for counterstain.

Analysis of the immunohistochemical results was performed by two investigators (J.V., P.P.B). The pattern of $\mathrm{p} 53$ nuclear overexpression was classified in four categories by estimating the percentage of stained tumor cells: - , no cells positive;,+ 1 to $10 \%$ positive tumor cells;,++ 10 to $50 \%$ positive tumor cells and,$+++>50 \%$ positive tumor cells. Cytoplasmic staining was not scored. 


\section{PCR-SSCP}

PCR-SSCP analysis (160) was performed to investigate p53 mutations in exons 5 to 8 . The intron primers for amplification of exons 5 to 8 were: $5 \mathrm{~S}$ (5'-tca-ctt-gtg-ccc-tga-ctt3'), 5AS (5'-gag-gaa-tca-gag-gcc-tgg-3'), 6S (5'-gag-acg-aca-ggg-ctg-gtt-3'), 6AS (5'gag-acc-cag-ttg-caa-acc-3'), 7S (5'-cca-agg-cgc-act-ggc-ctc-3'), 7AS (5'-gag-gca-agcaga-ggc-tgg-3'), 8S (5'-cct-tac-tgc-ctc-ttg-ctt-c-3'), 8AS (5'-tga-atc-tga-ggc-ata-act-3'). Genomic DNA (250 ng) was subjected to 35 cycles of PCR $\left(95,57\right.$ and $72^{\circ} \mathrm{C}$ for $0.5,2$ and 1.3 minutes, respectively). Exons 5, 6 and 8 were amplified in $50 \mu$ containing: 50 $\mathrm{mM} \mathrm{KCl}, 10 \mathrm{mM}$ Tris- $\mathrm{HCl}\left(\mathrm{pH} 8.8\right.$ ), $1.75 \mathrm{mM} \mathrm{MgCl}_{2}, 250 \mu \mathrm{M}$ deoxynucleotide triphosphates, $10 \mathrm{pmol}$ of each 5 'end-labeled primer and $1.5 \mathrm{U}$ of Taq polymerase (Perkin Elmer/Cetus, Norwalk, Connecticut, USA). Exon 7 was amplified in the same buffer containing $1.5 \mathrm{mM} \mathrm{MgCl}$.

Five microliters of the PCR product was diluted in $15 \mu$ l loading buffer $(96 \%$ formamide, $20 \mathrm{mM}$ EDTA, $0.05 \%$ bromophenol blue and xylene cyanol), boiled for 3 minutes and then quenched ( 10 minutes) on ice before loading ( $2 \mu \mathrm{l} /$ lane). Each sample was applied to a $5 \%$ polyacrylamide $(49: 1) /$ Tris-Borate EDTA $(0.5 x)$ gel with and without $10 \%(\mathrm{v} / \mathrm{v})$ glycerol. Subsequently, electrophoresis was performed at room temperature for 16 hours at 6 or $3 \mathrm{~W}$ respectively.

\section{Sequence Analysis}

Direct sequencing of the double stranded PCR products that showed a shift on the SSCP gels was performed as described previously (109). Amplified PCR products were purified using the magic PCR preps ${ }^{\text {tm }}$ DNA purification system (Promega, Madison, WI. USA). The PCR primers were used for sequencing in the dsDNA cycle sequencing system (Life Technologies, Inc, Gaithersburg, MD, USA). Electrophoresis was performed on $6 \%$ polyacrylamide (19:1) gels containing $7 \mathrm{M}$ ureum.

\section{Statistical Analysis}

The Kaplan-Meier method was used to estimate survival probability as a function of time. Differences in survival were analyzed by a log-rank test. The Chi-square test (with Yates correction if relevant) was used for the other correlations. 
Table 1. p53 Overexpression, clinıcal and pathological data for each patient.

\begin{tabular}{|c|c|c|c|c|c|c|}
\hline $\begin{array}{l}\text { Case } \\
\text { no. }\end{array}$ & $\begin{array}{l}\text { Age } \\
(y r)\end{array}$ & Stage/Grade & $\begin{array}{l}\text { p53 Immuno- } \\
\text { positivity }\end{array}$ & Recurrences & $\begin{array}{l}\text { Survival } \\
\text { (months) }\end{array}$ & Treatment $^{8}$ \\
\hline 1 & 77 & $a / 1-2$ & ++ & no & 31 & TURT \\
\hline 2 & 81 & $a / 1$ & - & $a / 2,8$ months & $>65$ & TURT \\
\hline 3 & 77 & $a / 1$ & - & no & $>58$ & TURT \\
\hline 4 & 73 & $a / 1$ & - & no & $>55$ & TURT,Ch \\
\hline 5 & 66 & $a / 3$ & ++ & $a / 2,8$ months & 23 & TURT,Ct,R,Ch \\
\hline 6 & 55 & $a / 1-2$ & - & a/2, 4 months & $>68$ & TURT,BCG,Ct \\
\hline 6 rec. & & $a / 2$ & + & & & \\
\hline 7 & 54 & $a / 1$ & - & no & $>46$ & TURT \\
\hline 8 & 50 & $a / 1$ & - & a/1, 8 months & $>84$ & TURT,BCG,Ch \\
\hline 9 & 88 & $a / 2$ & - & no & 52 & TURT,Ch \\
\hline 10 & 50 & $a-1 / 2$ & $+t$ & no & $>69$ & TURT \\
\hline 11 & 68 & $a-1 / 1$ & - & $1 / 2,4$ months & $>37$ & TURT \\
\hline 12 & 75 & $1 / 3$ & - & a/2, 6 months & $>72$ & TURT,BCG \\
\hline 13 & 92 & $1 / 2$ & + & $a / 2,11$ months & 73 & TURT,Ch \\
\hline 14 & 62 & $1 / 2$ & - & no & $>40$ & TURT,Ch \\
\hline 15 & 58 & $1 / 2$ & + & a/1, 9 months & $>50$ & TURT,BCG \\
\hline 16 & 71 & $1 / 1$ & - & a/2, 4 months & $>75$ & TURT \\
\hline 17 & 79 & $1 / 2$ & + & $a / 3,3$ months & 49 & TURT,Ch \\
\hline 17 rec. & & $a / 3$ & - & & & \\
\hline 18 & 77 & $1 / 2$ & + & no & $>58$ & TURT,Ch \\
\hline 19 & 72 & $1 / 2$ & + & a/2, 6 months & $>44$ & TURT,Ch,BCG \\
\hline 20 & 81 & $2 / 2$ & - & & 9 & TURT \\
\hline 21 & 73 & $2 / 2$ & + & & 8 & TURT,Ch,Ct \\
\hline 22 & 53 & $2 / 3$ & + & & $>50$ & TURT,R,Iridium \\
\hline 23 & 79 & $2 / 3$ & ++ & & 4 & $\mathrm{Cr}$ \\
\hline 24 & 81 & $2 / 2$ & - & & 6 & TURT \\
\hline 25 & 53 & $2 / 3$ & ++ & & 7 & TURT,Ch \\
\hline 26 & 70 & $2 / 3$ & ++ & & 3 & TURT,Ch \\
\hline 27 & 47 & $2 / 3$ & - & & 8 & TURT,Ch \\
\hline 28 & 67 & $\geq 2 / 3$ & - & & $>20$ & TURT,Ch,R \\
\hline 29 & 72 & $\geq 2 / 3$ & +++ & & $>85$ & TURT,Ch \\
\hline 30 & 79 & $\geq 2 / 3$ & + & & 10 & TURT,Ct \\
\hline 31 & 59 & $\geq 2 / 3$ & ++ & & 3 & TURT,R \\
\hline 32 & 73 & $2-3 / 3$ & ++ & & 2 & TURT,R \\
\hline 33 & 68 & $2-3 / 3$ & +++ & & 2 & TURT \\
\hline 34 & 63 & $3 / 3$ & ++ & & 5 & TURT,A \\
\hline 35 & 74 & $3 / 3$ & +++ & & 10 & $\mathrm{Ct}, \mathrm{Ch}$ \\
\hline 36 & 74 & $3 b / 2$ & ++ & & $>39$ & $\mathrm{Ct}$ \\
\hline 37 & 80 & $3 b / 3$ & - & & $>53$ & TURT,R,Ct \\
\hline 38 & 44 & $4 / 3$ & - & & 29 & TURT,Ct \\
\hline 39 & 82 & $4 / 2$ & - & & 5 & TURT \\
\hline
\end{tabular}

A Number of positive cells:,$- 0 \% ;+, 1-10 \%,++, 10-50 \% ;+++,>50 \%$, rec., recurrence;

${ }^{8} \mathrm{Ch}$, chemotherapy; $\mathrm{Ct}$, cystectomy; $\mathrm{R}$, radiotherapy; TURT, transurethral resection of the tumor. BCG, bacillus calmette-guerın instillations. 


\section{Results}

\section{Immunostaining patterns}

The DO-7 staining patterns of the four groups are shown in Figure 1. We defined a tumor as p53 positive if more than $10 \%$ of the tumor cells showed nuclear p53 expression. Of the 41 tumors studied, 13 showed p53 overexpression (Table 1).
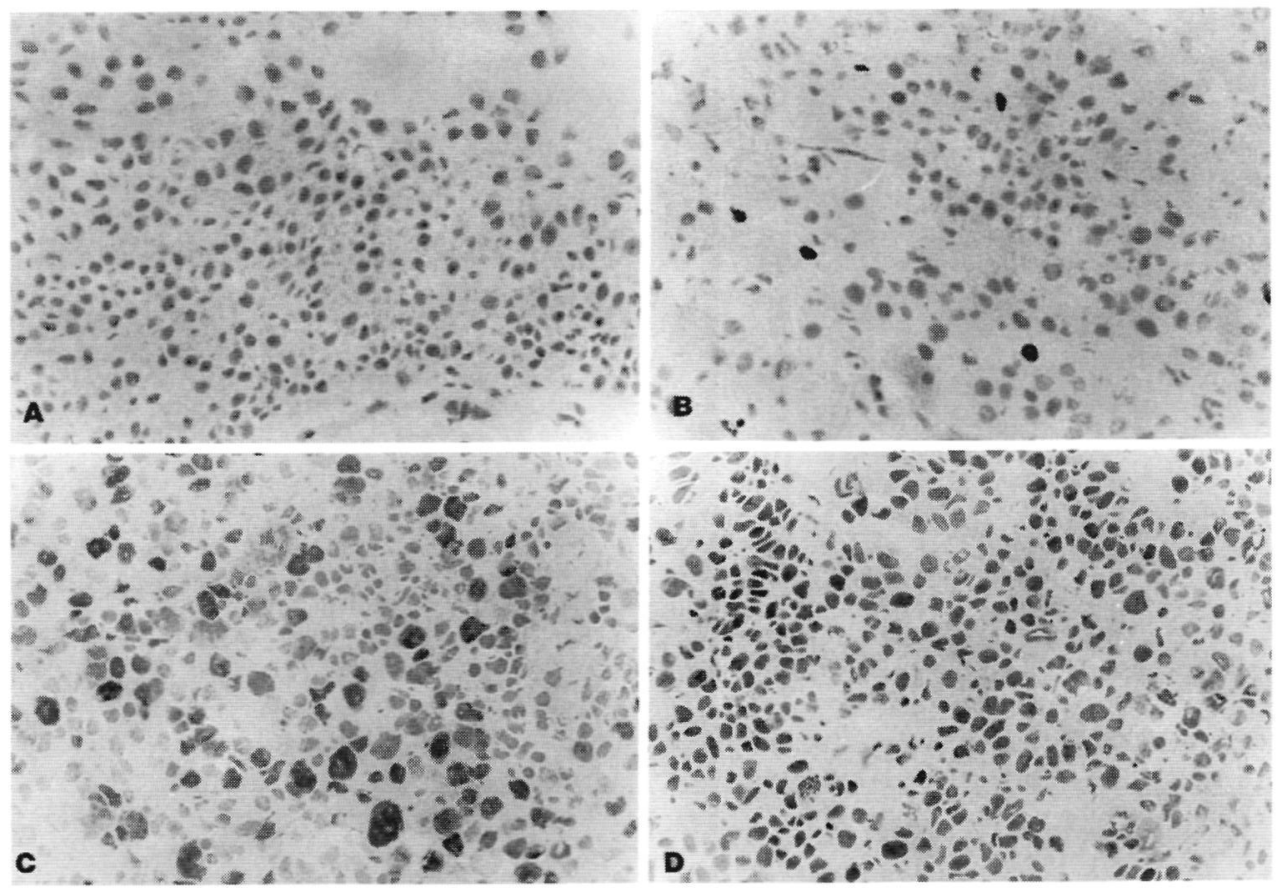

Figure 1. Immunohistochemical staining of p53 expression in transitional cell carcinomas using p53 antibody DO-7 A. Stage Ta grade 2 tumor, no tumor cells stained $10 \%=-1 \mathrm{~B}$. Stage T2 grade 2 tumor, a few tumor cells are stained $(1-10 \%=+)$ C. Stage T2 grade 3 tumor, heterogeneous staining $(10-50 \%=++)$ D. Stage T3 grade 3 tumor, clearly more than $50 \%$ of tumor cells show nuclear p53 overexpression $(>50 \%=+++)$ Original magnification, times 400 . 


\section{Correlation between tumor grade/stage and p53 overexpression}

p53 overexpression was found in $9 \%$ of the grade $1,23 \%$ of the grade 2 and $60 \%$ of the grade 3 tumors. Overexpression of $\mathrm{p} 53$ was found in $16 \%$ of the superficial tumors and in $50 \%$ of the invasive tumors $(\mathrm{p}<0.05$ ) (Table 2,3). p53 Mutations found by SSCP analysis showed a high correlation with both increasing grade $(\mathrm{p}<0.001)$ and stage $(p<0.001)(233)$.

Table 2. Correlation between p53 overexpression and grade.

\begin{tabular}{cccccc}
\hline & \multicolumn{3}{c}{ p53 immuno-positivity ${ }^{A}(n)$} & $\%$ immuno-positivity \\
\cline { 2 - 5 } Grade & - & + & ++ & +++ & $\%$ \\
\hline 1 & 9 & 1 & 1 & 0 & $9 \%$ \\
2 & 6 & 4 & 3 & 0 & $23 \%$ \\
3 & 4 & 2 & 6 & 3 & $60 \%$ \\
\hline
\end{tabular}

${ }^{A}$ Number of positive cells:,$- 0 \% ;+, 1-10 \% ;++, 10-50 \% ;+++,>50 \%$.

Table 3. Correlation between p53 overexpressıon and stage.

\begin{tabular}{cccccc} 
& \multicolumn{3}{c}{ p53 immuno-positivity ${ }^{A}(n)$} & $\%$ immuno-positivity \\
\cline { 2 - 5 } Stage & - & + & ++ & +++ & $\%$ \\
\hline superficial & 10 & 6 & 3 & 0 & $16 \%$ \\
invasive & 7 & 3 & 7 & 3 & $50 \%$ \\
\hline
\end{tabular}

A Number of positive cells:,$- 0 \% ;+, 1-10 \% ;++, 10-50 \% ;+++,>50 \%$.

\section{Correlation between p53 overexpression and survival}

The survival according to p53 overexpression is shown in Figure 2. For the whole group, a shorter survival time of patients with $\mathrm{p} 53$ overexpression was observed (Chi-square: $8.00, \mathrm{p}<0.01$, Figure 2a). Although statistical analysis was not possible, because of the small number studied, we observed a shorter survival time for patients with superficial bladder cancer that showed p53 overexpression (Figure 2b). Within the group with invasive disease, no significant difference in survival time between the patients with and without p53 overexpression was seen (Figure 2c). 
A

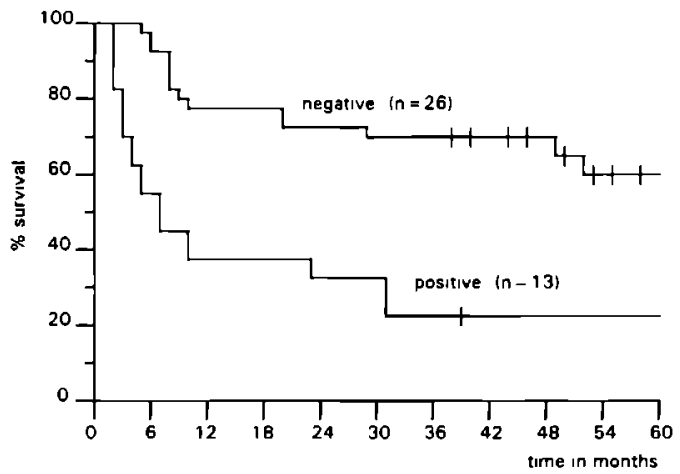

B

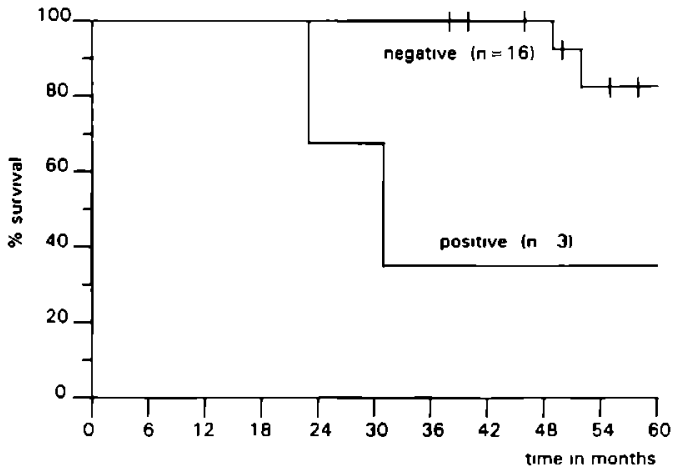

C

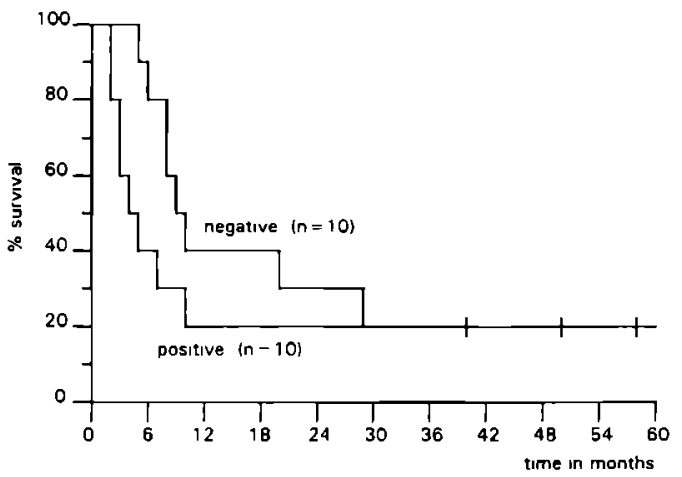

Figure 2. Kaplan Meier survival curves of bladder cancer patients accordıng to the presence or absence of overexpression of the p53 proteın.

A. All patıents ( $P<0.01$, log rank test). B. Patıents with superficıal (pTa, pT1) tumors (not significant). C. Patients with muscle invasive disease (not significant). 
Table 4. Relationship between p53 mutations analyzed by PCR-SSCP and p53 overexpression by immunostaning.

\begin{tabular}{|c|c|c|c|c|c|c|}
\hline & \multicolumn{4}{|c|}{ Immunostaınıng ${ }^{A}(n)$} & \multirow[t]{2}{*}{$<10 \%$} & \multirow[t]{2}{*}{$>10 \%$} \\
\hline & $\cdot$ & + & $+t$ & +++ & & \\
\hline \multicolumn{7}{|c|}{ P53 mutation/SSCP } \\
\hline No mutation & 18 & 8 & 7 & 0 & 77 & 23 \\
\hline Mutation & 2 & 0 & 3 & 3 & 25 & 75 \\
\hline Exon 5 & 1 & 0 & 1 & 1 & & \\
\hline Exon 6 & 0 & 0 & 0 & 1 & & \\
\hline Exon 7 & 0 & 0 & 1 & 0 & & \\
\hline Exon 8 & 1 & 0 & 1 & 1 & & \\
\hline
\end{tabular}

${ }^{A}$ Number of positive cells: $\cdot, 0 \% ;+, 1-10 \% ;++, 10-50 \% ;+++,>50 \%$.

\section{Comparison between p53 overexpression with p53 mutations found by PCR-SSCP}

The overall comparison of p53 mutations analyzed by PCR-SSCP and p53 overexpression assessed by immunohistochemistry (IHC) is shown in Table 4. The sensitivity of IHC, defined as percentage of IHC-positive tumors among tumors with identified mutation, was $75 \%$. The specificity of IHC, defined as percentage of IHCnegative tumors among neoplasms without a p53 mutation, was $77 \%$. Despite the good concordance between p53 mutation and p53 protein overexpression $(p<0.02), 23 \%$ (7/31) of the tumors without a p53 mutation as assessed by SSCP analysis showed p 53 overexpression.

Table 5. Comparıson Immunostaining and PCR-SSCP analysis for mutants.

\begin{tabular}{|c|c|c|c|c|c|}
\hline \multicolumn{2}{|c|}{ Histopathology } & \multicolumn{3}{|c|}{ p53 Mutation/SSCP } & \multirow[b]{2}{*}{ p53 Overexpression } \\
\hline $\begin{array}{c}\text { Case } \\
\text { no. }\end{array}$ & Stage/Grade & Exon & Codon & Amıno acıd change & \\
\hline 1 & $>2 / 3$ & 5 & 179 & CAT $\rightarrow$ TAT $(H i s \rightarrow T y r)$ & +++ \\
\hline 2 & $3 / 3$ & 8 & 285 & GAG $\rightarrow$ AAG $(G / u \rightarrow L y s)$ & +++ \\
\hline 3 & $4 / 3$ & 5 & 166 & TCA $\rightarrow$ TGA (Ser $\rightarrow$ umber $)$ & - \\
\hline 4 & $2 / 3$ & 8 & 282 & del. $G \rightarrow$ frameshıft & - \\
\hline 5 & $2 / 3$ & 5 & 158 & $\mathrm{CGC} \rightarrow$ CTC $($ Arg $\rightarrow$ Leu $)$ & ++ \\
\hline 6 & $2-3 / 3$ & 8 & 285 & GAG $\rightarrow$ AAG $(G / u \rightarrow L y s)$ & ++ \\
\hline 7 & $2-3 / 3$ & 6 & 215 & $\mathrm{AGT} \rightarrow \mathrm{GGT}(\mathrm{Ser} \rightarrow \mathrm{G} / \mathrm{y})$ & +++ \\
\hline 8 & $>2 / 3$ & 7 & 259 & $\mathrm{GAC} \rightarrow \mathrm{GTC}(A s p \rightarrow$ Van $)$ & ++ \\
\hline
\end{tabular}

${ }^{A}$ Number of positive cells:,$- 0 \% ;+, 1-10 \% ;++, 10-50 \% ;+++,>50 \%$. 
Table 5 shows the eight p53 mutants found by PCR-SSCP analysis. They all showed p53 overexpression except for cases 3 and 4, which showed no p53 immunoreactivity at all. These two cases contained a $\mathrm{C}$ to $\mathrm{G}$ transversion at codon 166 leading to a stopcodon and a deletion of a guanine nucleotide in codon 282 , resulting in a frameshift.

\section{Discussion}

This study compares the overexpression of the $\mathrm{p} 53$ protein assessed by $\mathrm{IHC}$ with $\mathrm{p} 53$ mutation determined by means of SSCP analysis in bladder cancer. We looked at both clinical and biologic aspects of p53 alterations. We chose a cut off of $10 \%$ p53 positive tumor cells for p53 overexpression. The appearance of occasionally stained cells in tumors, which we scored as negative, can be explained by the existence of clones of cells with a p53 mutation or by the occurrence of a genotoxic event that raises levels of wild type p53 protein in normal cells, resulting in cell cycle arrest $(80,111)$. More detailed examination of microdissected focally stained areas by means of mutation analysis (SSCP) has to be performed to address this problem and to check the biologic importance of this phenomenon.

The overexpression of $\mathrm{p} 53$ as assessed by IHC correlates with grade and stage $(\mathrm{p}<0.05)$. However, correlation between mutations in the p53 gene as determined by SSCP analysis and grade and stage was higher $(\mathrm{p}<0.001)(233)$. In concordance with other IHC studies $(47,126)$ we demonstrated that $\mathrm{p} 53$ overexpression is an unfavorable prognostic factor for bladder cancer patients $(p<0.01)$. No association between $p 53$ overexpression and decreased survival was found for invasive tumors, in contrast with other studies. Differences in the treatment of the patients and the different $\mathrm{Ab}$ and scoring systems used might explain these differences. Esrig and coworkers (47) showed that p53 overexpession is a significant predictor of tumor progression if the disease was confined to the bladder. However, no association between p53 overexpression and tumor progression was found if the disease is not confined to the bladder (pT3b, pT4). Because of the relatively small number in our study, we can not compare these two groups. The results of our study show that p53 overexpression has no additional prognostic value over stage, whereas for this same group of patients we found that E-cadherin may have 
additional prognostic value over stage (18). Apparently, other mechanisms can lead to tumor progression and they may override or bypass the function of $\mathrm{p} 53$.

The Kaplan Meier curves show the same result for p53 overexpression and p53 mutation (233) when the whole group and the invasive tumors are studied. For superficial tumors, however, three patients showed p53 overexpression without a mutation confirmed by SSCP analysis. Although this was not statistically significant, a trend was observed toward worse survival for the patients showing $\mathrm{p} 53$ overexpression. This was not observed when p53 mutations were analyzed, because we found no mutations at all in the group of superficial tumors. In high grade pT1 tumors, p53 overexpression had predictive value for progression of disease (181). These results, combined with the correlation of p53 overexpression with increasing grade and stage as shown here, imply that $\mathrm{p} 53$ overexpression plays a role in the progression of bladder cancer.

Analysis of p53 mutations at the molecular genetic level is rather difficult and time consuming and therefore is not suitable for routine use. IHC, however, is a standard technique in pathology laboratories. There is a good concordance between p 53 mutation and $\mathrm{p} 53$ overexpression in relation to grade, stage and survival, so $\mathrm{IHC}$ detection of p53 alterations is preferable as a predictor of prognosis. Furthermore, immunohistochemistry might reveal anomalies in the p53 pathway other than $\mathrm{p} 53$ mutations (see below).

A good concordance between p53 mutation by SSCP and p53 overexpression by IHC $(p<0.02)$ was observed. This strong correlation between high levels of $p 53$ protein and mutation in the p53 gene has previously been described for a number of tumor types, and this led to the hypothesis that mutant p53 gene products are characterized by conformational changes of the protein, resulting in a higher stability and consequently in accumulation of the protein. However, we have observed discrepancies between p53 mutation and $\mathrm{p} 53$ overexpression.

Of the eight tumors with a p53 mutation as assessed by SSCP, two tumors showed no p53 immunoreactivity at all. In one tumor sequence analysis showed a transversion in codon 166 of exon 5 generating a stop codon and thereby a truncated protein, which does not contain the nuclear localization domain at amino acids 316 to 325 (238). In the other tumor a deletion of a guanine nucleotide found in codon 282 of exon 8 gave rise to a frameshift, which also affected the downstream nuclear localization sequence. In both cases, the loss of the nuclear localization signal most likely prevented nuclear accumulation. and therefore IHC detection was impossible. 
In addition to these "false negatives", which can still be explained by the proposed theory of extended stabilization, we observed p53 overexpression in $23 \%$ of the tumors without any sign of p53 mutation as assessed by SSCP. This p53 overexpression without a concomitant mutation was also found in a considerable number of bladder tumors in two other studies $(34,46)$. Although we studied exons 5 to 8 , which are known to contain the majority of the p53 mutations (169) mutations outside this region and intron mutations might explain this result. Moreover, although SSCP is a sensitive method for detecting mutations (31), not all mutations are detected by this technique. The presence of nonneoplastic tissue, although reduced to $\leq 30 \%$, can lead to a negative SSCP result if the percentage of tumor cells overexpressing p 53 is approximately $10 \%$. This cannot be the explanation for $\mathrm{p} 53$ overexpression in the $23 \%$ of the tumors without a SSCP proven p53 mutation, because most of these tumors contained at least $20 \%$ of p53 overexpressing tumor cells.

All off the mechanisms leading to p53 overexpression are not yet fully understood. According to the already mentioned hypothesis, mutant p 53 would always be stable and wild type p53 would be unstable. Thus the tight correlation between mutation and overexpression could indicate a causal relationship. However, this is not always true. In fibroblasts obtained from Li-Fraumeni patients who carried heterozygote germ-line p53 mutations, the mutant p53 protein did not accumulate to a high level and was unstable like the wild type p53 (112). By contrast, in the tumors of these patients, when the wild type allele was lost, the mutant p53 protein did accumulate. Clearly, p53 mutation per se does not cause $\mathrm{p} 53$ protein accumulation.

Alternatively, wild type p53 can accumulate in some circumstances, e.g., as a result of complexing with viral oncoproteins $(110,124,184)$ and also with the cellular oncoprotein mdm2 (148). Accumulation of wild type p53 in normal tissue was shown to occur in a novel cancer family syndrome (7). One can hypothesize that anomalies elsewhere in the p53 pathway can result in stabilization of p53 proteins as well as in the ability to ignore its growth-suppressive commands.

We found p53 overexpression in $23 \%$ of the cases without any sign of a mutation, which is in concordance with two other studies $(34,46)$, so we suspect that some other event(s) in addition to mutation plays a role in stabilization. The viral oncoproteins are not relevant for the human system. The mdm2 oncoprotein has been implicated in the progression of bladder cancer (119). Whether mdm2 overexpression represents an 
altemative to p53 mutation in inactivating the p53 regulatory pathway is still unclear. Events other than mutation that lead to stability remain to be elucidated. It is noteworthy that $\mathrm{p} 53$ can accumulate in normal cells upon DNA damage. Thus some tumor cells behave as if they were in a permanent state of DNA damage (112). Additional research is necessary to characterize the signals that trigger this state and to understand the mechanisms through which this overexpression reflects alteration of p53 function and consequently gives rise to an altered phenotype in cancer cells. 


\title{
Chapter 3
}

\section{P53 mutations have no additional prognostic value over stage in bladder cancer.}

Jacquelıne AM Vet', Pierre Paul Bnnguier ${ }^{1}$, Pino J Poddıghe ${ }^{2}$, Herbert FM Karthaus ${ }^{3}$, Frans MJ Debruyne', Jack A Schalken ${ }^{1}$

\begin{abstract}
Evidence is accumulating that the tumor suppressor gene p53 is involved in the development of bladder cancer Therefore we studied p53 mutations in 47 bladder cancers obtained from 45 patients using polymerase chain reaction/ single-strand conformation polymorphism (PCRSSCP) analysis Eight out of 24 invasıve tumors appeared to have a p53 mutation while no p53 mutations were found in the superficial tumors All the p53 mutations were found in grade 3 tumors

The tumors with altered p53 showed a higher frequency of allelıc loss (FAL) compared to the tumors without a mutation (558\% versus $211 \%, \mathrm{p}<005$, by Chi-square test) This increase in FAL suggests a correlation between p 53 mutations and genetic instability

A significant correlation between mutated p53 and poor survival in the whole group studied was found ( $p<0001$, by log rank test) However, within the group of muscle-invasive tumors the occurrence of p53 mutations had no additional prognostic value Therefore, even though p53 mutations were found in aggressive tumors, the clinical usefulness of its detection seems limited

Nevertheless, these results implicate that p53 is involved in the clinical behavior of bladder cancer, and especially its role in the progression of superficial cancer to invasive disease needs further attention
\end{abstract}

Departments of Urology' and Pathology ${ }^{2}$, Unıversity Hospital, Nımegen, The Netherlands and the department of Urology ${ }^{3}$, Canisius Wilhelmına Hospital, Nijmegen, The Netherlands This study was supported by the Dutch cancer foundation, NUKC 9102 (J A M V) and IKL 8807 (P J P) and the foundation for urological scientific exchange (FUSEX) (P P B ) Published in Br $J$ Cancer $70 \quad 496-500,1994$ 


\section{Introduction}

Bladder cancer is the fifth most common cancer in the western male population, with an annual incidence of 20 cases per 100,000. The incidence in women is lower, about 5 cases per 100,000 are diagnosed annually (173). Transitional cell carcinoma of the bladder is divided in two groups: A) superficial (pTis, pTa, pT1) and B) muscle invasive (pT2, pT3, pT4) disease. Most superficial bladder cancers have a good prognosis, however $10-25 \%$ clinically progress to a more aggressive state, showing an increase in grade and/or infiltration into the muscle layer. pT1 tumors invade the lamina propria and have a higher incidence of progression than the pTa tumors, which are confined to the urothelium. Patients with invasive tumors usually present de novo and have a worse prognosis. Non random chromosomal changes were observed in bladder cancer, for example, in cytogenetic studies monosomy of chromosome 9 has been reported $(70,88,202,231)$. Using restriction fragment length polymorphism analysis (RFLP), allelic loss of chromosomes 9,11 and 17 in bladder cancer has been demonstrated (221). Abnormalities of chromosome $11 \mathrm{p}$ appeared to be more frequent in invasive- than in superficial tumors and monosomy of chromosome 9 was not correlated with grade or stage. Loss of heterozygosity (LOH) of chromosome $17 \mathrm{p}$ occurred only in high-grade (G3) tumors (159). The p53 gene is considered the candidate tumor suppressor gene on chromosome $17 \mathrm{p}$, since in cancer development, frequently one of the two alleles is lost and the remaining is mutated $(6,87)$. Recently, it has been suggested that $\mathrm{p} 53$ acts as a cell cycle control protein at the level of $\mathrm{Gl}$ to $\mathrm{S}$ phase transition $(99,129,253)$. The loss of this function may result in an increased genetic instability (253). In bladder cancer it has been shown by means of subcloning and sequencing of exon 5 through 9 that $17 p$ allelic loss is strongly associated with p53 mutation ( 9 out of 10 cases) and that out of 18 invasive tumors $61 \%$ have a 553 mutation (199). This association of p53 mutations and invasive tumors was confirmed in another study by using the technique of PCR-SSCP (64).

We studied p53 mutations in a group of 45 patients with bladder cancer, using PCRSSCP analysis. Besides a correlation with grade and stage we investigated the prognostic significance of $\mathrm{p} 53$ mutations. Since p53 mutations are thought to be associated with genetic instability $(99,129,253)$ we also studied the correlation of p53 mutations and genetic instability evaluated by the frequency of allelic loss. 


\section{Materials and methods}

\section{Tumor specimens}

Twenty-three snap frozen superficial carcinomas (pTa-pT1) and 24 muscle invasive carcinomas $(\mathrm{pT} \geq 2)$ obtained from 45 patients have been analyzed. Superficial tumors comprised 2 recurrences of previously analyzed tumors. Among the invasive tumors 2 were squamous cell carcinomas. All the other tumors were transitional cell carcinomas. Pathological and clinical data for the patients are summarized in Table I. Genomic DNA was extracted from step-sectioned tumors ( $>70 \%$ tumor cells) (144).

\section{PCR-SSCP and sequence analysis}

PCR-SSCP and sequence analysis were performed as described in chapter 2 .

\section{Restriction fragment length polymorphism}

DNA probes used : chromosome 9q: EFD 126 (152), chromosome 11p: H-ras (172), chromosome 16q: pV962 (135) and 79.2.23 (19), chromosome 17p: 144D6 (192), chromosome 18q: 15.65 (50). RFLP analysis was performed on the 24 patients from whom normal DNA was available (168). The RFLP results were used to determine the frequency of allelic loss (FAL), also called fractional allelic loss (236).

\section{Statistical analysis}

The Kaplan-Meier method was used to estimate survival probability as a function of time. Differences in survival were analyzed by a Log-rank test. Chi-square test was used for the other correlations. 
Table 1. p53 Mutations, clinical and pathological data for each patient.

\begin{tabular}{|c|c|c|c|c|c|c|}
\hline \multirow[b]{2}{*}{ Case no } & \multirow[b]{2}{*}{$\begin{array}{l}\text { Age } \\
(y r)\end{array}$} & \multirow[b]{2}{*}{ Stage/Grade } & \multicolumn{2}{|r|}{ p53 Mutations } & \multirow[b]{2}{*}{$\begin{array}{l}\text { Survival } \\
\text { (months) }\end{array}$} & \multirow[b]{2}{*}{ Treatment ${ }^{A}$} \\
\hline & & & Exon/Codon & Amino acid change & & \\
\hline 1 & 77 & $a / 1-2$ & & & 31 & TURT \\
\hline 2 & 75 & $a / 1$ & (p) & & $>41$ & TURT \\
\hline 3 & 72 & $a / 1$ & & & $>38$ & TURT \\
\hline 4 & 68 & $a / 1$ & & & $>41$ & TURT,C \\
\hline 5 & 66 & $a / 3$ & & & 23 & TURT, $\mathrm{Ct}, \mathrm{R}, \mathrm{CH}$ \\
\hline 6 & 66 & $a / 2$ & & & $>57$ & TURT, $\mathrm{Ct}$ \\
\hline 7 & 49 & $a / 2$ & & & $>45$ & TURT, BCG,Ct \\
\hline 7 rec. & & $a / 2$ & & & & \\
\hline 8 & 62 & $a / 1$ & & & $>64$ & TURT \\
\hline 9 & 53 & $a / 1$ & & & $>61$ & TURT,BCG \\
\hline 10 & 42 & $a / 1$ & & & $>65$ & TURT,BCG,Ch \\
\hline 11 & 88 & $a / 2$ & & & 52 & TURT,Ch \\
\hline 12 & 44 & $a \cdot 1 / 2$ & & & $>39$ & TURT \\
\hline 13 & 65 & $a-1 / 1$ & & & $>22$ & TURT \\
\hline 14 & 68 & $1 / 3$ & & & $>55$ & TURT,BCG \\
\hline 15 & 86 & $1 / 2$ & & & $>58$ & TURT,Ch \\
\hline 16 & 76 & $1 / 2$ & & & 9 & TURT, $\mathrm{Ch}$ \\
\hline 17 & 53 & $1 / 2$ & & & $>37$ & TURT,BCG \\
\hline 18 & 64 & $1 / 1$ & & & $>55$ & TURT \\
\hline 19 & 85 & $1 / 2$ & (p) & & $>45$ & TURT,Ch \\
\hline 19 rec & & $a / 3$ & (p) & & & \\
\hline 20 & 71 & $1 / 2$ & (p) & & $>36$ & TURT, Ch \\
\hline 21 & 68 & $1 / 2$ & & & $>36$ & TURT,Ch,BCG \\
\hline 22 & 81 & $2 / 2$ & & & 9 & TURT \\
\hline 23 & 73 & $2 / 2$ & & & B & TURT, Ch, Ct \\
\hline 24 & 49 & $2 / 3$ & & & $>36$ & TURT, $R_{i}$ Iridıum \\
\hline 25 & 79 & $2 / 3$ & $5 / 158$ & $\mathrm{CGC} \rightarrow \operatorname{CTC}(\operatorname{Arg} \rightarrow L e u)$ & 4 & $\mathrm{Ct}$ \\
\hline 26 & 81 & $2 / 2$ & & & 6 & TURT \\
\hline 27 & 53 & $2 / 3$ & & & 7 & TURT,Ch \\
\hline 28 & 70 & $2 / 3$ & & & 3 & TURT,Ch \\
\hline 29 & 47 & $2 / 3$ & $8 / 282$ & del. $G \rightarrow$ frameshıft & 8 & TURT,Ch \\
\hline 30 & 62 & $\geq 2 / 3$ & & & $>27$ & TURT, $\mathrm{Ch}, \mathbf{R}$ \\
\hline 31 & 65 & $\geq 2 / 3$ & $5 / 179$ & $\mathrm{CAT} \rightarrow$ TAT $(H / S \rightarrow$ TVr $)$ & $>66$ & TUAT, $\mathrm{Ct}$ \\
\hline 32 & 83 & $\geq 2 / 3$ & & & 21 & TURT,R \\
\hline 33 & 79 & $\geq 2 / 3$ & & & 10 & TURT, Ct \\
\hline 34 & 59 & $\geq 2 / 3$ & $7 / 259$ & $\mathrm{GAC} \rightarrow \mathrm{GTC}($ Asp $\rightarrow$ Van & 3 & TURT,R \\
\hline 35 & 73 & $2-3 / 3$ & $8 / 285$ & GAG $\rightarrow$ AAG $(G / u \rightarrow L y s)$ & 2 & TURT,R \\
\hline 36 & 73 & $2-3 / 3$ & & & 9 & TURT \\
\hline 37 & 76 & $2-3 / 2, \mathrm{SCC}$ & & & 32 & TURT, Ct,R \\
\hline 38 & 68 & $2-3 / 3$ & $6 / 215$ & AGT $\rightarrow$ GGT $(\mathrm{Ser} \rightarrow G / y)$ & 2 & TURT \\
\hline 39 & 63 & $3 / 3$ & & & 5 & TURT, R \\
\hline 40 & 74 & $3 / 3$ & $8 / 285$ & GAG / AAG $(G / u \rightarrow L y s)$ & 10 & $\mathrm{Cl}, \mathrm{Ch}$ \\
\hline 41 & 50 & $3 / 2, \mathrm{SCC}$ & & & 5 & TURT \\
\hline 42 & 70 & $3 b / 2$ & & & $>28$ & $\mathrm{Ct}$ \\
\hline 43 & 75 & $3 b / 3$ & & & $>40$ & TURT, R, Ct \\
\hline 44 & 44 & $4 / 3$ & $5 / 166$ & TCA $\rightarrow$ TGA (Ser $\rightarrow$ umber $)$ & 29 & TURT, Ct \\
\hline 45 & 82 & $4 / 2$ & & & 5 & TURT \\
\hline
\end{tabular}

SCC, squamous cell carcinoma; (p), polymorphisin codon 213; rec., recurrence,

${ }^{A} \mathrm{Ch}$, chemotherapy; $\mathrm{Ct}$, cystectomy, $\mathrm{R}$, radiotherapy; TURT, transurethral resection of the tumor. $B C G$, bacıllus calmette-guerın instıllatıons. 


\section{Results}

\section{p53 mutations in bladder cancer}

Table 1 summarizes the results of the PCR-SSCP and sequence analysis of the p53 gene in bladder tumors of 45 patients. Eight mutations were found in invasive tumors: three in exon 5 , one in exon 6 , one in exon 7 and three in exon 8 . Seven out of the eight mutations found were point mutations, while one appeared to be a deletion of a $G$, leading to a frameshift. We found four transitions: two $G$ to $A$, one $A$ to $G$, one $C$ to $T$ and three transversion: one $\mathrm{C}$ to $\mathrm{G}$, one $\mathrm{G}$ to $\mathrm{T}$ and one $A$ to $T$. In three patients with a superficial tumor a similar shift in the SSCP pattern of exon 6 was observed. One of these also showed loss of heterozygosity of chromosome $17 \mathrm{p}$. After sequencing it appeared that the shift in the SSCP pattern was due to a silent alteration of CGA to CGG at codon 213. This polymorphism was already described before (139). No mutations were found in the squamous cell carcinomas.

\section{Correlation between tumor stage/grade and $\mathrm{p53}$ mutations}

All the p53 mutations are found in grade 3 tumors, as is shown in Table $2 a(p<0.001)$. In the group of superficial tumors no mutations have been found, while the invasive tumors have in 8 out of $24(33 \%)$ cases a p53 mutation $(p<0.001)$ (Table $2 b)$. This is in good agreement with previous observations $(64,199)$.

Table 2a. Relationshıp between p53 mutation and grade.

\begin{tabular}{cccc} 
& \multicolumn{2}{c}{$\mathrm{p53}$ mutation } & \\
\cline { 2 - 3 } Grade & negative & positive & $\%$ mutations \\
\hline 1 & 11 & 0 & 0 \\
2 & 15 & 0 & 0 \\
3 & 11 & 8 & 42 \\
\hline
\end{tabular}

Table 2b. Relatıonshıp between p53 mutation and stage.

\begin{tabular}{lccc} 
& \multicolumn{2}{c}{$\mathrm{p} 53$ mutation } & \\
\cline { 2 - 3 } \multicolumn{1}{c}{ Stage } & negative & positive & \% mutations \\
\hline Superficial & 21 & 0 & 0 \\
Invasive & 16 & 8 & 33 \\
\hline
\end{tabular}


Table 3a. Allelic loss of chromosomes $9 q, 11 p, 16 q, 17 p, 18 q$ and $p 53$ mutations in bladder tumors.

\begin{tabular}{|c|c|c|c|c|c|c|c|}
\hline \multirow[t]{2}{*}{$\begin{array}{c}\text { Case } \\
\text { no. }\end{array}$} & \multirow[t]{2}{*}{ Stage/Grade } & \multirow[t]{2}{*}{ p53 Mutation } & \multicolumn{5}{|c|}{$\begin{array}{c}\text { RFLP analysıs } \\
\text { Chromosomal region }\end{array}$} \\
\hline & & & $9 q$ & $11 p$ & $16 q$ & $17 p$ & $18 q$ \\
\hline 1 & $a / 1$ & - & 0 & $\mathrm{O}$ & 0 & 0 & $\mathrm{O}$ \\
\hline 2 & $a / 1$ & - & 0 & $\mathrm{O}$ & 0 & 0 & $\mathrm{NI}$ \\
\hline 3 & $a / 1$ & $-(p)$ & 0 & $\mathrm{O}$ & 0 & $\mathrm{O}$ & 0 \\
\hline 4 & $a / 1$ & - & 0 & $\mathrm{O}$ & 0 & 0 & $\mathrm{NI}$ \\
\hline 5 & $a / 1$ & - & 0 & NI & 0 & $\mathrm{NI}$ & 0 \\
\hline 6 & $a / 1-2$ & - & $\mathrm{O}$ & 0 & 0 & 0 & 0 \\
\hline 7 & $a / 1-2$ & - & 0 & 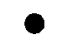 & $\mathrm{O}$ & 0 & 0 \\
\hline $7 \mathrm{rec}$. & $a / 1-2$ & - & 0 & 0 & 0 & 0 & 0 \\
\hline 8 & $1 / 2$ & $-(p)$ & 0 & 0 & 0 & 0 & ND \\
\hline 8 rec. & $a / 3$ & $-(p)$ & 0 & $\mathrm{O}$ & 0 & 0 & 0 \\
\hline 9 & $a / 2$ & - & 0 & NI & 0 & 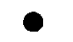 & 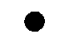 \\
\hline 10 & $a / 2-3$ & - & $\mathrm{NI}$ & $\mathrm{O}$ & 0 & 0 & $\mathrm{NI}$ \\
\hline 11 & $1 / 2$ & $-(p)$ & 0 & $\mathrm{O}$ & $\mathrm{O}$ & $\mathrm{O}$ & $\mathrm{Nl}$ \\
\hline 12 & $1 / 2$ & - & 0 & 0 & $\mathrm{O}$ & 0 & $\mathrm{NI}$ \\
\hline 13 & $1 / 2$ & - & 0 & 0 & 0 & 0 & $\mathrm{NI}$ \\
\hline 14 & $1 / 2$ & - & 0 & $\mathrm{O}$ & 0 & 0 & 0 \\
\hline 15 & $1 / 2$ & - & $\mathrm{NI}$ & 0 & 0 & 0 & 0 \\
\hline 16 & $1-2 / 1-2$ & - & 0 & NI & 0 & 0 & 0 \\
\hline 17 & $2 / 3$ & - & 0 & 0 & - & 0 & $\mathrm{NI}$ \\
\hline 18 & $2 / 3$ & + & $\mathrm{NI}$ & NI & 0 & 0 & 0 \\
\hline 19 & $>2 / 3$ & - & NI & NI & 0 & $O$ & $\mathrm{NI}$ \\
\hline 20 & $>2 / 3$ & + & 0 & $\mathrm{O}$ & 0 & 0 & 0 \\
\hline 21 & $3 / 3$ & - & 0 & $\mathrm{O}$ & $\mathrm{O}$ & $\mathrm{NI}$ & ND \\
\hline 22 & $3 / 3$ & . & $\mathrm{NI}$ & 0 & 0 & 0 & ND \\
\hline 23 & $3 / 3$ & + & $\mathrm{NI}$ & NI & 0 & 0 & ND \\
\hline 24 & $4 / 3$ & + & 0 & NI & $\mathrm{O}$ & 0 & 0 \\
\hline
\end{tabular}

-, no p53 mutation; +, p53 mutation; O, no LOH; $\bullet$, LOH; NI, not informative;

ND, not determıned; rec., recurrent tumor; $(p)$, polymorphısm at codon 213.

Table 3b. Frequency of allelic loss according to p53 mutation.

\begin{tabular}{ccc}
\hline p53 Mutation & Number of tumors & FAL $\%$ \\
\hline negative & 22 & 21.1 \\
positive & 4 & 55.8 \\
\hline
\end{tabular}

\section{Relation between p53 mutations and frequency of allelic loss}

As a measure for genetic instability we used frequency of allelic loss (FAL). FAL was based on RFLP analysis using probes for chromosomes 9q, 11p, 16q, 17p and 18q 
(Table 3a). LOH of $17 p$ was found in 7 tumors. Four tumors showed a p53 mutation, while in two a polymorphism at codon 213 was found. No mutations were found in the tumors without $17 \mathrm{p} \mathrm{LOH}$. The tumors with a p53 mutation show a FAL of $55.8 \%$, those without a mutation have a FAL of $21.1 \%(\mathrm{p}<0.05)$ (Table $3 \mathrm{~b})$.

\section{Correlation of p53 mutation and survival}

The survival according to 553 mutation for the whole group of 45 patients is shown in the Kaplan-Meier curve (Figure 1a). The patients with a p53 mutation survived for a shorter period of time $\left(\chi^{2}=11.25, \mathrm{p}<0.001\right)$. There was no significant association between the presence of a p53 mutation and decreased survival among patients with invasive disease $\left(\chi^{2}=1.46\right.$, n.s.) (Figure $\left.1 b\right)$.
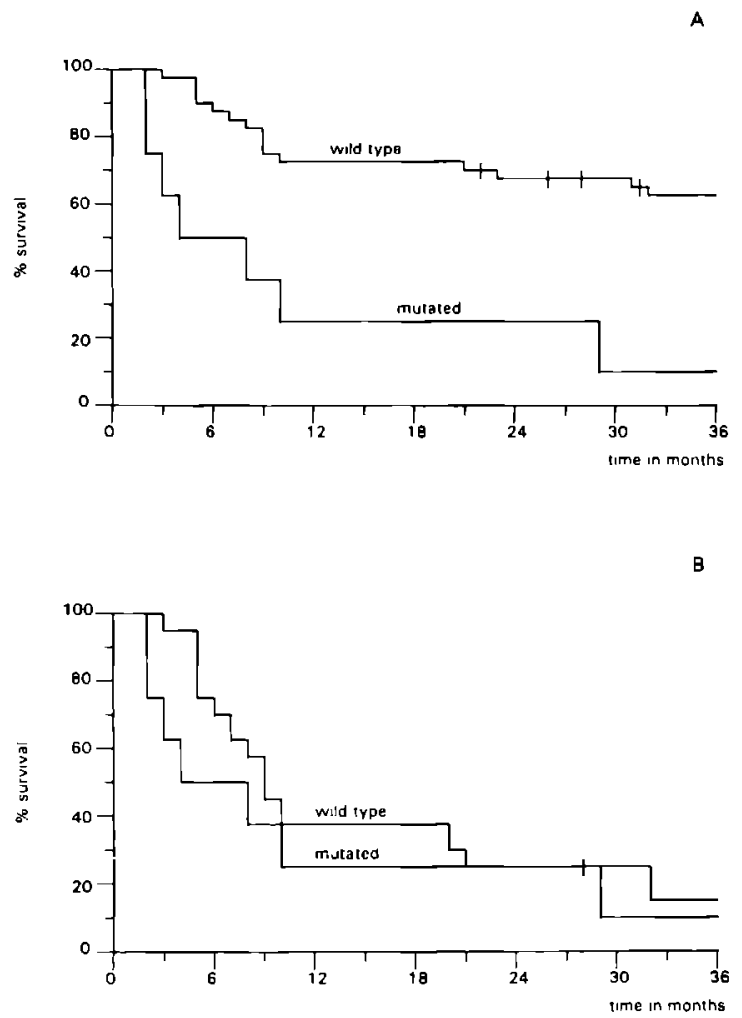

Figure 1. Three year survival $(\%)$ of bladder cancer patients according to the presence or absence of $p 53$ mutatıons. A. All patıents ( $<<0.001$ by log rank test) B. Patıents with muscle invasive tumors ( $p=$ not significant) 


\section{Discussion}

In this study, we examined mutations in the p53 gene by PCR-SSCP analysis. We show that the occurrence of p53 mutations correlates with grade and stage, which is in concordance with previous studies (64.199). A p53 mutation was found in 8/24 (33\%) of the invasive tumors, which were all grade 3 .

The p53 tumor suppressor gene is known to be mutated in many types of cancer (87) and during tumor progression one of the two alleles is often lost resulting in a reduction of growth control (6). However, some p53 mutations are known to be dominant negative: the protein produced by the mutated allele has the ability to bind and inactivate the remaining wild-type product (237). In our study we did not find any mutation without LOH of $17 \mathrm{p}$. On the contrary one patient with $17 \mathrm{p} \mathrm{LOH}$ has no $\mathrm{p} 53$ mutation. It could be that the mutation is outside the region of the $\mathrm{p} 53$ gene studied or that a second locus distinct from p53 is involved (188).

Wild-type p53 has been suggested to be a cell cycle control protein since progression from $\mathrm{Gl}$ to $\mathrm{S}$ phase is often blocked in cells expressing high levels of this protein $(99,129,253)$. It has been shown that cells without wild-type p53 protein failed to show growth arrest (when placed in a condition unfavorable for the S-phase completion) and gene amplification occurs (253), which can be considered as a form of genetic instability. As p53 mutations are known to occur in bladder cancer $(64,199)$, we used frequency of allelic loss as an indicator for genetic instability (236). The high frequency of allelic loss found in tumors with a p53 mutation $(55.8 \%, \mathrm{p}<0.05)$ suggests a correlation with genetic instability. This increase in allelic loss in tumors with a p53 mutation could be explained by an altered G1-S cell cycle checkpoint which can be the result of the loss of the wild-type p53 function. The loss of certain alleles, e.g. those harboring tumor suppressor genes, could provide selective advantages during tumor progression by generating variants with a more aggressive phenotype (52). FAL showed no significant correlation with grade or stage.

In breast cancer p53 mutations are inversely correlated with survival (2). This study is the first report investigating the prognostic significance of p53 mutations in bladder cancer. The results demonstrate that p53 mutations are an unfavorable prognostic factor ( $<<0.001$ ) for the whole group studied. However, among patients with invasive tumors there was no significant association between the presence of a p53 mutation and a 
decreased survival. Therefore patients without a p53 mutation are not ensured to have a good prognosis. There are other features that can lead to an inactive p53 protein: such as complexing with other proteins (148), or other genetic events can occur that result in a poor prognosis. EGFR positivity is shown to be associated with tumor progression and decreased survival (154). Also no significant difference between EGFR positivity and survival among patients with invasive tumors was found. Furthermore, recently it has been shown that decreased E-cadherin expression correlates with the clinical aggressiveness of bladder cancer (18).

The variable order of appearance of genetic alterations in oncogenesis suggests that rather accumulation, than the order of occurrence, is important for tumor progression (52). The increased frequency of allelic loss we find in the tumors with a p53 mutation can lead to tumor progression and poorer prognosis. But as mentioned above there are other mechanisms which can lead to tumor progression and these may overrule or bypass the function of $\mathrm{p} 53$.

Recently immunohistochemical studies have shown p53 overexpression to be correlated with poor survival $(126,181)$. In pTl bladder tumors Sarkis et al. found a clear correlation between nuclear overexpression of $\mathrm{p} 53$ protein and disease progression. The study of Lipponen showed a significant correlation between p53 overexpression and decreased survival for the entire cohort and for the muscle-invasive tumors. However for the pTa and pT1 tumors only a trend was found. In muscle-invasive tumors, we found no association between $\mathrm{p} 53$ mutations and decreased survival. This difference stresses again the discordance of p53 immunohistochemistry and p53 mutation analysis (214). The discrepancy in prognostic value for $\mathrm{p} 53$ mutations in superficial disease found in the two immunohistochemical studies, can be the result of the use of different antibodies and the scoring system used. We found no p53 mutations in superficial tumors, which can be explained by the lack of grade 3 tumors in this group.

The results of our study indicate that the presence of a p53 mutation is an unfavorable prognostic factor for the whole group studied, but it has no additional prognostic value for the group of muscle invasive tumors. The step at which p53 mutations occur in the tumor progression cascade of bladder cancer is still unclear. In this respect grade 3 superficial tumors deserve more attention. In general superficial bladder cancer has a good prognosis, however, $10-25 \%$ of these tumors progress to an invasive stage. 
Therefore the correlation between prognosis and p53 mutation in this subgroup is of particular interest.

Furthermore the discordance of immunohistochemical and p53 mutation analysis indicate that comparative analysis of p53 mutations and overexpression of the p53 oncoprotein in progression of the $\mathrm{pTa}$ and $\mathrm{pT} 1$ tumors are necessary.

\section{Acknowledgments}

We would like to thank Dr. W.B. Isaacs for his helpful discussion. 


\title{
Chapter 4
}

\section{Predictive value of p53 mutations analyzed in bladder washings for progression of high risk superficial bladder cancer.}

Jacqueline AM. Vet, J. Alfred Witjes, Salvatore AE. Marras, Daphne Hessels, Henk G. van der Poel, Frans MJ Debruyne, Jack A. Schalken.

\begin{abstract}
To assess the value of p53 mutations in predicting the progression of superficial bladder cancer (TCC) and to define exactly when p53 mutations occur in the process of tumor progression, 80 consecutive bladder washings from 26 high risk (indicated by quantitative karyometric analysis) superficial TCC patients were examined by Single Strand Conformation Polymorphism (SSCP). Six out of 13 patients who experienced clinical progression (to $p T \geq 2$ ) were found to have a p53 mutation in one or more of their bladder washings. In the control group (no progression to invasive disease) only 1 out of 13 patients had a p53 mutation. For these high risk superficial TCC patients the occurrence of a p53 mutation has a positive predictive value of $86 \%$ for the progression of disease. A negative predictive value of $63 \%$ was observed. Moreover, since p53 mutations were found in samples prior to progression (with a mean of 8 months) it could identify patients who need a change in the treatment strategy in order to prevent progression to invasive disease. In spite of these promising results, it is obvious that to increase not only the positive predictive value but especially the negative predictive value of this procedure to predict progression, additional prognostic markers are still needed.
\end{abstract}

Department of Urology, University hospital Nijmegen, Nijmegen, The Netherlands. This work wals supported by a grant from the Dutch Cancer Society (NUKC9102) Clinical Cancer Research in press. 


\section{Introduction}

Transitional cell carcinoma (TCC) is the most common histologic type of bladder cancer, presenting with a wide spectrum of clinical and pathological appearances. Superficial TCC accounts for approximately $80 \%$ of all newly diagnosed tumors in the bladder (204). Thirty to $90 \%$ of these tumors will recur depending on stage, grade, multifocality and treatment modality, however, only $10-25 \%$ become invasive or metastasize during the course of the disease $(74,102)$. Early identification of patients whose superficial bladder tumors will progress is very important, since a change in their treatment strategy can have a major impact on the outcome of disease. The morbidity of cystectomy, which at the moment is the only treatment to prevent progression to invasive disease, emphasizes the urgent need for markers that identify patients at risk for tumor progression.

The p53 tumor suppressor gene, located on chromosome $17 \mathrm{pl} 3.1$, is known to be involved in the development of bladder cancer. Allelic deletions of $17 p$ were predominantly observed in invasive tumors and to a lesser extent in high grade superficial TCC, but were absent in low grade Ta tumors $(36,77,159)$. Mutations in the p53 tumor suppressor gene frequently occur in bladder cancer and appear to correlate with grade and stage $(64,199,233)$. The relatively high frequency of p53 mutations in T2-T4 tumors compared to T1 tumors suggests their involvement in the progression of T1 tumors to invasive disease (207). However, the exact point at which p53 mutations occur during tumor progression from superficial ( $\mathrm{Ta}$ ) tumors to lamina propria invasive (T1) and muscle invasive (T2-T4) tumors is still unclear.

The tumor suppressor protein p53 appears to play a role as transcriptional regulator $(54,134)$ and acts as a cell cycle control protein at the level of $G 1$ to $S$ phase transition $(99,129)$. In case of DNA damage, p53 can delay the progression through the cell cycle. to permit DNA repair (134) or can initiate programmed cell death (apoptosis) (132). The upregulation by $\mathrm{p} 53$ of $\mathrm{p} 21$, an inhibitor of $\mathrm{G} 1$ cyclin-dependent kinases, appears to be responsible for p53 mediated growth arrest (94). Recently, Smith and coworkers showed that Gadd45 which is also upregulated by p53, probably serves as a link between the p53-dependent cell cycle checkpoint and DNA repair (203). The loss of these p53 regulatory functions can result in replication of incorrect DNA, leading to increased genetic instability (253). 
From a large prospective study in which approximately 3000 bladder washings were investigated by quantitative karyometric analysis (228) we selected 26 patients who were indicated to be high risk (i.e. suspected for recurrences) on basis of this analysis. We studied the value of p53 mutations as a additional prognostic marker in this group of high risk superficial TCC patients, using PCR-SSCP analysis. In order to define when p53 mutations occur during natural history of these tumors we analyzed consecutive bladder washings from the same patients.

\section{Materials and methods}

\section{Specimens}

Eighty consecutive bladder washing specimens from 13 patients with high risk superficial TCC who underwent clinical progression to invasive disease ( $\mathrm{pT} \geq 2)$ and 13 patients (age/sex/follow-up matched) who did not experience progression were analyzed. As a control group 35 bladder washings from 11 patients with a low risk karyometric score and no progression of disease were analyzed. The bladder washings were obtained from a large prospective study in which bladder washings of patients were collected for quantitative karyometric analysis (228). If patients were diagnosed with superficial TCC, bladder washings were collected and analyzed with three to twelve months intervals. All patients were designated as high risk superficial TCC on basis of quantitative karyometric analysis (228) and intermediate or high risk by calculating their prognostic index score based on tumor stage, multicentricity, recurrence rate and number of bladder areas involved (101). All patients received optimal intravesical therapy (e.g. Bacillus Calmette-Guerin instillations) as soon as they were considered to have a high risk superficial bladder tumor. Clinical and pathological data for the high risk patients are summarized in Table 1.

The bladder was washed with $50 \mathrm{cc}$ saline that was immediately mixed with an equal volume Carbowax (50\% ethanol, $2 \%$ polyethyleneglycol (PEG 1500)) for fixation. After centrifugation, the supernatant was decanted and the pellet resuspended in $3 \mathrm{ml}$ of Carbowax and stored at $-20^{\circ} \mathrm{C}$.

For DNA isolation $150 \mu \mathrm{l}$ of bladder washing material was centrifuged for 5 minutes at $13000 \mathrm{rpm}$. After decanting the supernatant, the pellet was washed two times with a 
mixture of acetone/methanol (1 1 ) Subsequently, the cells were lysed in $50 \mu$ lysis buffer (10 mM TrisHCl pH $88,400 \mathrm{mM} \mathrm{NaCl}, 2 \mathrm{mM}$ EDTA, $045 \%$ Tween $20^{\text {tm }}$ and $045 \%$ Nonidet $\mathrm{P} 40$ ) with $05 \mu \mathrm{g} / \mu \mathrm{l}$ proteinase $\mathrm{K}$, for 1 hour at $60^{\circ} \mathrm{C}$ Proteinase $\mathrm{K}$ was inactivated by boiling the sample for 5 minutes

\section{PCR-SSCP}

PCR-SSCP analysis was performed to investigate p53 mutations in exons 5 through 9 (160) Exon 8 and 9 were amplified together The intron primers for amplification were 5S (5'-tca-ctt-gtg-ccc-tga-ctt-3'), 5AS (5'-gag-gaa-tca-gag-gcc-tgg-3'), 6S (5'-gag-acgaca- ggg-ctg-gtt-3'), 6AS (5'-gag-acc-cca-gtt-gca-aac-3'), 7S (5'-cca-agg-cgc-act-ggc-ctc3'), 7AS (5'-gcg-gca-agc-aga-ggc-tgg-3'), 8/9S (5'-cct-tac-tgc-ctc-ttg-ctt-c-3'), 8/9AS (5'aaa-ctt-tcc-act-tga-taa-3')

A $2 \mu$ l aliquot of bladder washing DNA solution was subjected to 40 cycles of PCR, 05 minutes at $95^{\circ} \mathrm{C}, 2$ minutes at $55^{\circ} \mathrm{C}$ and 13 minutes at $72^{\circ} \mathrm{C}$

Exons $5,6,8 / 9$ were amplified in $50 \mu$ containing $50 \mathrm{mM} \mathrm{KCl}, 10 \mathrm{mM}$ Tris-HCL (pH $88), 175 \mathrm{mM} \mathrm{MgCl}_{2}, 250 \mu \mathrm{M}$ deoxynucleotide triphosphates $10 \mathrm{pmol}$ of each primer, $3 \mu \mathrm{C} \alpha^{32} \mathrm{P}$-dATP and 15 units of Taq polymerase (Perkın Elmer/Cetus, Norwalk, Connecticut, USA) Exon 7 was amplified in the same buffer containing $14 \mathrm{mM}$ magnesium chloride

Five microliters of the PCR product were diluted in $15 \mu \mathrm{l}$ of loading buffer $(96 \%$ formamide, $20 \mathrm{mM}$ EDTA, $005 \%$ bromophenol blue and xylene cyanol), boiled for 3 minutes and then quenched ( $10 \mathrm{~min}$ ) on 1ce before loading ( $2 \mu \mathrm{l}$ per lane) Each sample was applied to a $5 \%$ polyacrylamide/Tris-borate EDTA $(05 \mathrm{x})$ gel with $10 \%(\mathrm{v} / \mathrm{v})$ glycerol Subsequently, electrophoresis was performed at room temperature for 16 hours at $6 \mathrm{~W}($ exon $8 / 9$ ) and $5 \mathrm{~W}$ (exon $5,6,7$ ) respectively

\section{Sequence analysis}

Sequencing of the double stranded PCR products that showed a mobility shift on the SSCP gel was performed as previously described (109) Direct sequencing of the amplified product was performed in cases where the intensity of the mutant DNA fragment was $\geq 50 \%$ of the wild-type DNA fragment Whenever the intensity of the shifted DNA fragment was $\leq 50 \%$, we excised the mutant fragment from the polyacrylamide gel and the gel piece was immersed in $100 \mu 1$ of a $20 \mathrm{mM}$ Tris ( $\mathrm{pH} 80$ ) 
$1 \mathrm{mM}$ EDTA solution and heated at $80^{\circ} \mathrm{C}$ for 15 minutes. The extract was briefly vortexed and incubated overnight at $4^{\circ} \mathrm{C}$. After brief centrifugation $10 \mu \mathrm{l}$ of the supernatant was subjected to PCR reamplification for 45 cycles.

Before sequencing, the amplified PCR products were subjected to electrophoresis on an $2 \%$ low-melt agarose gel and further purified with the Magic Preps ${ }^{\text {tm }}$ DNA purification system (Promega, Madison, WI, USA). For sequencing in the AmpliCycle ${ }^{\text {tm }}$ system (Perkin Elmer/Cetus, Norwalk, Connecticut, USA) we used internal primers: $5 S$ (5'-tgtctc-ctt-cct-ctt-cct-ac-3'), 6S (5'-ggt-ccc-cag-gcc-tct-gat-tc-3'), 7S (5'-tct-tgg-gcc-tgt-gttgtc-tc-3'), 8S (5'-ttg-ctt-ctc-ttt-tcc-tat-cc-3'), 9S (5'-cac-ctt-tcc-ttg-cct-ctt-tc-3'). Electrophoresis was performed on a $6 \%$ polyacrylamide (19:1) gel containing $7 \mathrm{M}$ urea.

Table 1. Clinical and pathological ${ }^{A}$ data correlatıng with bladder washings of high risk superficial bladder cancer patients, respectively with and without progression of disease.

\begin{tabular}{|c|c|c|}
\hline & Progression $(n)$ & No progression $(n)$ \\
\hline \multicolumn{3}{|l|}{ Stage } \\
\hline $\mathrm{Ta}$ & 6 & 5 \\
\hline $\mathrm{Ta}+\mathrm{CIS}$ & - & 1 \\
\hline $\mathrm{T} 1$ & 3 & 4 \\
\hline $\mathrm{T} 1+\mathrm{CIS}$ & 2 & 2 \\
\hline CIS & 2 & 1 \\
\hline \multicolumn{3}{|l|}{ Grade } \\
\hline 1 & 1 & - \\
\hline 2 & 4 & 6 \\
\hline 3 & 6 & 6 \\
\hline Age (mean in years) & 69.1 & 65 \\
\hline Sex ratıo (M/F) & $11 / 2$ & $11 / 2$ \\
\hline \multicolumn{3}{|l|}{ follow-up } \\
\hline (mean in months) & 50.5 & 53.9 \\
\hline (range in months) & $(13-91)$ & $(31-83)$ \\
\hline
\end{tabular}

\footnotetext{
^Pathological data at the moment of first quanticyt sample, in case no pathological data are present previous diagnosis is taken into account, $M$, male, $F$, female
} 


\section{Results}

\section{SSCP analysis}

PCR-SSCP analysis of exons 5 through 9 was performed on DNA isolated from bladder washings. Figure $1 \mathrm{~A}$ shows in lane 5 and 6 , next to the wild type DNA fragments corresponding to exon 5 , a clear mobility shift. The intensity of the wild type DNA fragments compared to the mutated fragment could most likely be explained by the presence of normal cells (wild type p53 phenotype) in the bladder washing. Figure 1B shows in lane 6, a clear mobility shift of the DNA fragment corresponding to exons 8/9 that were amplified together. The intensity of the mutated DNA fragment implies that in most cells in this bladder washing the p 53 gene is mutated.

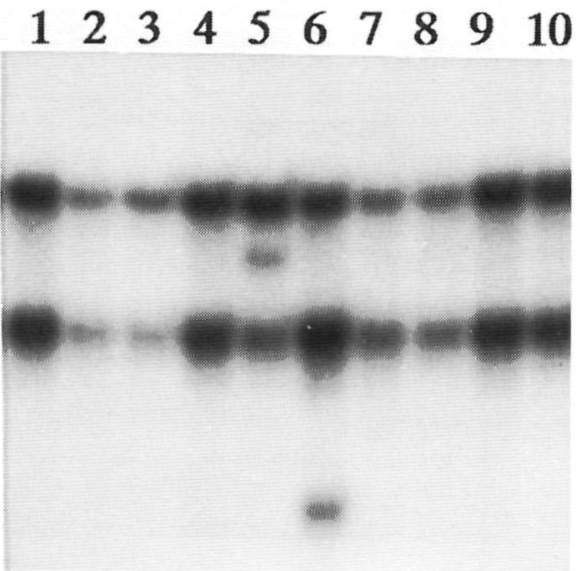

Figure $1 \mathrm{~A}$.

PCR-SSCP analysis of exon 6 in bladder washings of patients with superficial TCC. Mobility shifts are observed in lanes 5 and 6.

\section{3 \\ $\begin{array}{llll}4 & 5 & 6 & 7\end{array}$}
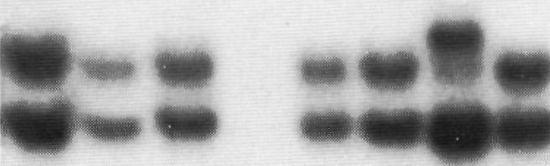

Figure 1B.

PCR-SSCP analysis of exon $8 / 9$ in bladder washings of patients with superficial TCC. A mobility shift is observed in lane 6 .

Figure 1C shows the sequence analysis result of the antisense strand of exon 6 (case \#3); a transition from a $\mathrm{T}$ to a $\mathrm{C}$ is shown at codon 205 resulting in a change of a tyrosine to a lysine. Mobility shifts were observed in eight patients (Table 2). Mutations were found once in exon 5, two times in exon 6 and four times in exon 8 . In one patient (case \#1) two different mutations were detected in the consecutive bladder washings analyzed. A different mobility shift was observed by SSCP-analysis, in concordance with the different nucleotide change. We found four transitions; twice a $G$ to A, once a A to $G$ 
and three transversions; a $T$ to $G$ and twice a $G$ to $C$. In case \#5 the known polymorphism in codon 213 of exon 6 (139) was detected. The identified point mutation, i.e. an $A$ to $G$ transversion did not result in an amino acid change (Table 2).

case $\# 3$

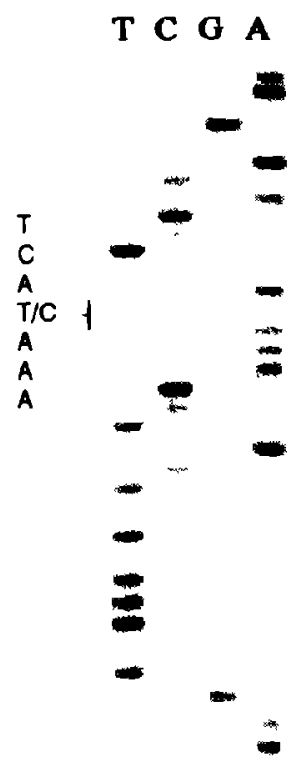

Figure 1C. Sequence analysis of the antisense strand of exon 6 (case \#3); a mutation from $T$ to $C$ is shown at codon 205 resulting in a change of a tyrosine to a lysine.

\section{Correlation p53 mutation and progression of disease}

To assess the additional prognostic value of $\mathrm{p} 53$ mutations for superficial TCC indicated to be high risk on basis of quantitative karyometric analysis, p53 mutations were analyzed in bladder washings of 26 patients (Table $2 a$ and $b$ ). p53 Mutations were found in 6 out of 13 patients ( $46 \%$ ) with progressive superficial bladder cancer (Table 2a). One out of 13 patients $(7.7 \%)$ with no progression of disease ( 23 month follow up) (Table 2b) showed a p53 mutation. The positive predictive value of p53 mutations for progression of high risk superficial TCC was $86 \%(6 / 7)$. The observed negative predictive value was $63 \%(12 / 19)$. To assess when p53 mutations occur during the process of tumor progression, consecutive bladder washings from the same patient were analyzed. 
Table 2. p53 Mutations analyzed (PCR-SSCP) in consecutive bladder washıngs of patients with superficial bladder cancer.

A. Patients with progression of disease (high risk)

\begin{tabular}{|c|c|c|c|c|}
\hline Case no. & Year $^{A}$ & Stage/Grade ${ }^{B}$ & p53 Mutation & Amıno acıd change \\
\hline 1 & $\begin{array}{l}90 \\
92\end{array}$ & $\begin{array}{l}a / 1 \\
2 / 3\end{array}$ & $\begin{array}{l}\text { exon } 8 \\
\text { exon } 8\end{array}$ & $\begin{array}{l}\text { codon } 285 / \mathrm{GAG} \rightarrow \mathrm{AAG} / \mathrm{G} / \mathrm{\rightarrow} \rightarrow \text { Lys } \\
\text { codon } 281 / \mathrm{GAC} \rightarrow \mathrm{CAC} / \text { Asp } \rightarrow \text { His }\end{array}$ \\
\hline 2 & $\begin{array}{l}92 \\
93 \\
93\end{array}$ & 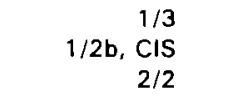 & $\begin{array}{l}\text { exon } 5 \\
\text { normal } \\
\text { nd }\end{array}$ & nd \\
\hline 3 & $\begin{array}{l}90 \\
91 \\
91 \\
91 \\
92\end{array}$ & $\begin{array}{r}a / 2 \\
a / 2 \\
1 / 2 b \\
1 / 3, \mathrm{CIS} \\
4 / 3\end{array}$ & $\begin{array}{l}\text { normal } \\
\text { normal } \\
\text { normal } \\
\text { exon } 6 \\
\text { exon } 6\end{array}$ & $\begin{array}{l}\text { codon } 205 / \text { TAT } \rightarrow \text { TGT } / \text { Tyr } \rightarrow \text { Lys } \\
\text { codon } 205 / \text { TAT } \rightarrow \text { TGT / Tyr } \rightarrow \text { Lys }\end{array}$ \\
\hline 4 & $\begin{array}{l}93 \\
94\end{array}$ & $\begin{array}{r}1 / 3, \text { CIS } \\
>2 / 3\end{array}$ & $\begin{array}{l}\text { exon } 8 \\
\text { exon } 8\end{array}$ & $\begin{array}{l}\text { codon } 273 / \mathrm{CGT} \rightarrow \mathrm{CAT} / \text { Arg } \rightarrow \text { His } \\
\text { codon } 273 / \mathrm{CGT} \rightarrow \text { CAT / Arg } \rightarrow \text { His }\end{array}$ \\
\hline 5 & $\begin{array}{l}90 \\
91 \\
92 \\
92\end{array}$ & $\begin{array}{r}\text { CIS } \\
N R \\
\text { atypla } \\
4 a / 2-3\end{array}$ & $\begin{array}{l}\text { exon } 6^{c} \\
\text { exon } 6 \\
\text { exon } 6 \\
\text { exon } 6\end{array}$ & $\begin{array}{l}\text { codon } 213 / \mathrm{CGA} \rightarrow \mathrm{CGG} / \text { Arg } \rightarrow \text { Arg } \\
\text { nd } \\
\text { codon } 213 / \mathrm{CGA} \rightarrow \mathrm{CGG} / \text { Arg } \rightarrow \text { Arg } \\
\text { codon } 213 / \mathrm{CGA} \rightarrow \mathrm{CGG} / \text { Arg } \rightarrow \text { Arg }\end{array}$ \\
\hline 6 & $\begin{array}{l}91 \\
91\end{array}$ & $\begin{array}{l}\text { CIS } \\
2 / 3\end{array}$ & $\begin{array}{l}\text { exon } 6 \\
\text { normal }\end{array}$ & codon $194 /$ CTT $\rightarrow$ CGT / Leu $\rightarrow$ Arg \\
\hline 7 & $\begin{array}{l}92 \\
93 \\
94 \\
94 \\
94\end{array}$ & $\begin{array}{r}\text { NA } \\
N A \\
\mathrm{CIS} \\
1 / 3, \mathrm{CIS} \\
4 a / 3\end{array}$ & $\begin{array}{c}\text { normal } \\
\text { normal } \\
\text { normal } \\
\text { normal } \\
\text { nd }\end{array}$ & \\
\hline 8 & $\begin{array}{l}91 \\
92 \\
92\end{array}$ & $\begin{array}{l}\text { NR } \\
1 / 3 \\
2 / 3\end{array}$ & $\begin{array}{l}\text { normal } \\
\text { normal } \\
\text { normal }\end{array}$ & \\
\hline 9 & $\begin{array}{l}93 \\
93 \\
94 \\
94 \\
94 \\
94\end{array}$ & $\begin{array}{r}1 / 3, \mathrm{CIS} \\
\mathrm{NA} \\
\mathrm{CIS} ? \\
\mathrm{CIS} ? \\
\mathrm{NR} \\
2 / 3\end{array}$ & $\begin{array}{c}\text { normal } \\
\text { normal } \\
\text { exon } 8 \\
\text { exon } 8 \\
\text { normal } \\
\text { normal }\end{array}$ & $\begin{array}{l}\text { nd } \\
\text { codon } 280 / \mathrm{AGA} \rightarrow \text { AAA } / \text { Arg } \rightarrow L y s\end{array}$ \\
\hline 10 & $\begin{array}{l}92 \\
94 \\
94\end{array}$ & $\begin{array}{l}\text { NR } \\
\text { NR } \\
\geq 2\end{array}$ & $\begin{array}{l}\text { normal } \\
\text { normal } \\
\text { normal }\end{array}$ & \\
\hline 11 & $\begin{array}{l}91 \\
93 \\
93\end{array}$ & $\begin{array}{c}\text { a/2 } \\
\text { sq metasplasıa } \\
\text { (CT CIS + positive } \\
\text { Iymph nodes) }\end{array}$ & $\begin{array}{l}\text { normal } \\
\text { nd }\end{array}$ & \\
\hline 12 & $\begin{array}{l}94 \\
95\end{array}$ & $\begin{array}{l}1 / 3 \\
4 / 3\end{array}$ & $\begin{array}{l}\text { normal } \\
\text { normal }\end{array}$ & \\
\hline 13 & $\begin{array}{l}92 \\
94\end{array}$ & $\begin{array}{l}a / 2 \\
2 / 3\end{array}$ & $\begin{array}{l}\text { normal } \\
\text { nd }\end{array}$ & \\
\hline
\end{tabular}

\footnotetext{
A vear of bladder wash sampling, ${ }^{B}$ of concomitant tumors, ${ }^{C}$ known polymorphısm (139),

"not representative sample; CT, cystectomy; NR, no abnormalities seen by cytoscopy,

nd, not determıned, sq, squamous; CIS?, suspicion for presence ol CIS
} 


\section{Table 2.}

B Patıents without progressıon of disease (high risk).

\begin{tabular}{|c|c|c|c|c|}
\hline Case no & Year $^{A}$ & Stage/Grade ${ }^{B}$ & p53 Mutatıon & Amıno acıd change \\
\hline 14 & $\begin{array}{l}91 \\
92 \\
93 \\
94 \\
94\end{array}$ & $\begin{array}{r}1 / 3 \\
\text { NR } \\
\text { NR } \\
\mathrm{a} / 3, \mathrm{CIS} \\
\mathrm{NR}\end{array}$ & $\begin{array}{l}\text { normal } \\
\text { normal } \\
\text { exon } 8 \\
\text { exon } 8 \\
\text { normal }\end{array}$ & $\begin{array}{l}\text { codon } 280 / \text { AGA } \rightarrow \text { ACA } / \text { Arg } \rightarrow \text { Thr } \\
\text { codon } 280 / \text { AGA } \rightarrow \text { ACA } / \text { Arg } \rightarrow \text { Thr }\end{array}$ \\
\hline 15 & $\begin{array}{l}91 \\
91 \\
92 \\
94\end{array}$ & $\begin{array}{c}\text { recurrences } \\
\text { recurrences } \\
\text { a/1 } \\
\text { papıllary multıple }\end{array}$ & $\begin{array}{l}\text { normal } \\
\text { normal } \\
\text { normal } \\
\text { normal }\end{array}$ & \\
\hline 16 & $\begin{array}{l}90 \\
91 \\
92\end{array}$ & $\begin{array}{r}a / 2 b \\
a / 3, C / S \\
1 / 3\end{array}$ & $\begin{array}{l}\text { normal } \\
\text { normal } \\
\text { normal }\end{array}$ & \\
\hline 17 & $\begin{array}{l}90 \\
91 \\
93 \\
94 \\
94\end{array}$ & $\begin{array}{r}a / 2 a \\
1 / 3 \\
a / 2 b \\
a / 2 a, C I S \\
\text { papillary multıple }\end{array}$ & $\begin{array}{l}\text { normal } \\
\text { normal } \\
\text { normal } \\
\text { normal } \\
\text { normal }\end{array}$ & \\
\hline 18 & $\begin{array}{l}90 \\
91 \\
93\end{array}$ & $\begin{array}{r}a / 2 b \\
\mathrm{NR} \\
1 / 2, \mathrm{CIS}\end{array}$ & $\begin{array}{l}\text { normal } \\
\text { normal } \\
\text { normal }\end{array}$ & \\
\hline 19 & $\begin{array}{l}91 \\
93\end{array}$ & $\begin{array}{r}a / 2 a \\
N R\end{array}$ & $\begin{array}{l}\text { normal } \\
\text { normal }\end{array}$ & \\
\hline 20 & $\begin{array}{l}90 \\
91\end{array}$ & $\begin{array}{l}1 / 2 b \\
1 / 2 b\end{array}$ & $\begin{array}{l}\text { normal } \\
\text { normal }\end{array}$ & \\
\hline 21 & $\begin{array}{l}91 \\
92 \\
94\end{array}$ & 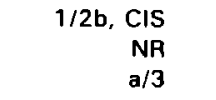 & $\begin{array}{l}\text { normal } \\
\text { normal } \\
\text { normal }\end{array}$ & \\
\hline 22 & $\begin{array}{l}92 \\
92\end{array}$ & $\begin{array}{l}1 / 2, \text { CIS } \\
1 / 2, \text { CIS }\end{array}$ & $\begin{array}{l}\text { normal } \\
\text { normal }\end{array}$ & \\
\hline 23 & $\begin{array}{l}92 \\
93 \\
93\end{array}$ & $\begin{array}{r}a / 3, \text { CIS } \\
\text { NR } \\
\text { NR }\end{array}$ & $\begin{array}{l}\text { normal } \\
\text { normal } \\
\text { normal }\end{array}$ & \\
\hline 24 & $\begin{array}{l}92 \\
92 \\
93 \\
94\end{array}$ & $\begin{array}{r}\text { NA } \\
\text { tumor } \\
\text { NR } \\
\text { NR }\end{array}$ & $\begin{array}{l}\text { normal } \\
\text { normal } \\
\text { normal } \\
\text { normal }\end{array}$ & \\
\hline 25 & $\begin{array}{l}92 \\
94 \\
94\end{array}$ & $\begin{array}{c}\text { NR } \\
\text { NA } \\
\text { papillary multıple }\end{array}$ & $\begin{array}{l}\text { normal } \\
\text { normal } \\
\text { normal }\end{array}$ & \\
\hline 26 & $\begin{array}{l}92 \\
93 \\
94 \\
94\end{array}$ & $\begin{array}{c}\text { NR } \\
\text { NR } \\
\text { NR } \\
\text { papillary lesion }\end{array}$ & $\begin{array}{l}\text { normal } \\
\text { normal } \\
\text { normal } \\
\text { normal }\end{array}$ & \\
\hline
\end{tabular}

\footnotetext{
A year of bladder wash sampling, ${ }^{a}$ of concomitant tumors sample,
} NR, no abnormalities seen by cytoscopy 
The occurrence of a p53 mutation in the course the disease in individual patients $(n=7)$ is summarized in Figure 2. Out of these 7 patients, 6 showed progression. It is noteworthy that the p53 mutations were detected in bladder washings with a mean of 8 months (range 4-14) before progression to invasive disease. From two patients (case \#2 and \#4) no bladder washings were available from the first period of disease (resp., 58 and 6 months). The first analyzed sample showed in both cases a mutation, followed by progression to invasive disease after respectively 9 and 5 months. In two patients (case \#3 and \#9) first the wild type genotype was found. Within 12 and 9 months respectively, a mutation was detected followed by the occurrence of an invasive tumor 7 and 9 months later. In two patients (case \#1 and \#6) mutated p53 was detected at first diagnosis followed by progression to invasive disease after respectively 14 and 4 months. In only one patient (case \#15) a p53 mutation was not followed by progression to invasive disease; 2 years after diagnosis the mutated p53 was observed in the bladder washings, but until now (23 months later) no progression to invasive disease has been observed. The histologic data of the tumors resected from the bladder at the moment of the first appearance of a p53 mutation in the bladder washings are shown in Table 2.

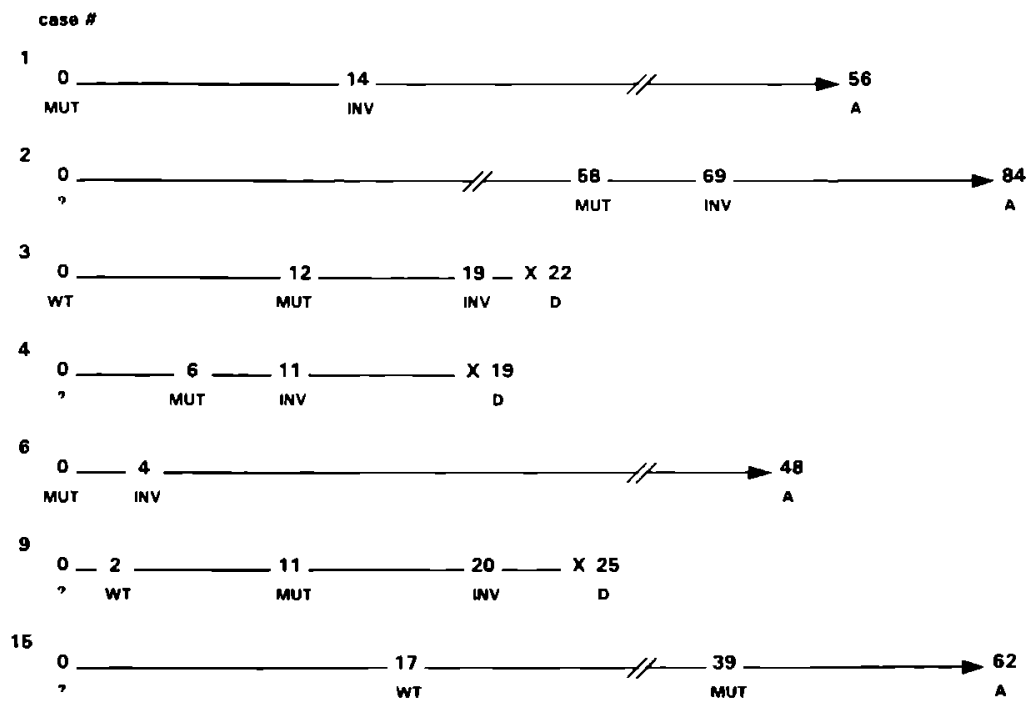

Figure 2. Timıng p53 mutations in tumor progression cascade. $0=$ first diagnosıs; ${ }^{>}=$ no bladder wash avallable; $W T=$ wild type p53; MUT = mutated p53; INV = occurrence of Invasıve tumor $(p T \geq 2) ; A=$ alıve; $D=$ dead; tıme in months. 


\section{Discussion}

Compared to superficial TCC, invasive disease constitutes an considerably greater threat to the patient's health. Since $10-25 \%$ of superficial TCC progress to invasive disease $(74,101)$, prediction of tumor progression is an important issue in bladder cancer management. Multifocal occurrence of bladder tumors suggests a general disease of the urothelium rather than a localized process. In this respect both voided urine and bladder washings have the advantage over histological biopsies in that they reflect the general status of the bladder mucosa since cells from the entire bladder are sampled. In 1945 Papanicolaou had already shown that exfoliation of tumor cells in the urine is a powerful diagnostic tool for detection and grading of patients with TCC of the bladder (164). However, the sensitivity for detecting low grade tumors and the reproducibility of this cytological grading system is disturbingly low (196). Since bladder washings enable the harvest of more and better preserved material compared to voided urine $(1,255)$, van der Poel and coworkers applied quantitative karyometric analysis (2c Deviation Index and nuclear shape) to bladder washings in order to increase both the reproducibility and sensitivity of the cytological analysis (228). The sensitivity for detecting low grade tumors increased substantially by using this analysis and additionally $86 \%$ of all tumor recurrences were preceded by a cytoscopically negative sample with positive karyometric score (Van der Poel et al., unpublished data). Notwithstanding this improvement, we attempted to enhance the clinical usefulness of this screening procedure by adding an additional marker. Although mutations in the p53 tumor suppressor gene frequently occur in bladder cancer and correlate with grade and stage $(64,199,233,207)$, until now it has remained unclear exactly when during the tumor progression process p53 mutations occur. We choose to analyze mutations in the p53 gene directly because of the more objective nature of this analysis compared to immunohistochemical studies. Variation between immunohistochemical studies caused by different antibodies and scoring systems $(5,233)$ can make comparison difficult. For superficial bladder cancer a clear prognostic significance for p53 overexpression has been shown $(47,181,182,194)$, however conflicting data were also reported $(66,126)$. Despite the fact that p53 accumulation and mutation of the p53 gene are well correlated, in $20-30 \%$ of the cases they appear to be separate events $(46,163,234)$, so there is no obligate causal relationship between mutation and protein overexpression. 
Last year Hruban and coworkers showed that in the case report of Hubert $\mathrm{H}$. Humphrey, a p53 mutation was present in a urine-cytology specimen 9 years before an infiltrating carcinoma of the bladder occurred (93). It should be noted that in this study the mutation was first analyzed in the histological tissue and then retrospectively the known mutation was detected in the urine specimen. Although the method used is very sensitive it has limited clinical relevance. In our study we used PCR-SSCP analysis and applied it directly to bladder washings in order to define when $\mathrm{p} 53$ mutations take place during the tumor progression process and moreover assess the additional prognostic value of p53 mutation analysis for patients who were indicated to be at high risk for recurrences on basis of their quantitative karyometric analyses (228).

In the present study we found p53 mutations in the samples of all patients prior to progression, with a mean of approximately 8 months (range 4-14). Of two patients (case $\# 2$ and \#4) however, in the earlier course of their disease, no bladder washings were done. Case \#4 was diagnosed 6 months before the first mutation was found so the period between the first p53 mutation and progression could have been at most, 11 months. Case \#2 could have had the mutation much longer since we have no bladder washing samples from the first 58 months of disease. In only one patient (case \#15) the appearance of a p53 mutation has not yet been followed by progression to invasive disease ( 23 month follow up). A drawback of analyzing p53 mutations in bladder washings is illustrated by the absence or low number of mutated p 53 cells in the bladder washing specimens of case \#6 and \#9 in the presence of a concomitant invasive tumor. The existence of the p53 mutation in the invasive tumor was confirmed by analyzing the histological material (data not shown). It is obvious that relevant cells are not sampled and a mutation can be missed if a tumor grows into the bladder wall or is covered by normal urothelium.

We observed identical p53 mutations in the consecutive bladder washings of four patients, which in favor with the theory of the clonal origin of bladder tumors (200). However, there was one exception, case $\# 1$, in which we found different p53 mutations in the individual bladder washings, implicating that the tumors resulted from two independent transforming events. These results are in agreement with the observed different $\mathrm{p} 53$ gene mutations in CIS or dysplasia and consecutive invasive tumors in two patients in a previous study (207). 
Six out of 13 patients that clinically progressed (to $\mathrm{p} T \geq 2$ ) showed a p53 mutation in one or more of their bladder washings. In the control group (no progression) only 1 out of 13 patients showed a p53 mutation. In the group of superficial TCC patients at risk for recurrence, the occurrence of a $\mathrm{p} 53$ mutation has a positive predictive value for progression to invasive disease of $86 \%$.

We observed a negative predictive value of $63 \%$. This low negative predictive value implicates that, although a p53 mutation indicates a malignant potential for the tumor, the absence of a p53 mutation does not guarantee a good prognosis, which we have already demonstrated for invasive bladder tumors (233). Other mechanisms as well can lead to tumor progression and these may override or bypass the function of p53. For example, overexpression of the epidermal growth factor receptor (EGFR) in patients with superficial TCC has been shown to correlate with several malignant features and a worse prognosis $(127,154,155)$. E-cadherin is a potential candidate with predictive value for progression of superficial TCC, but its clinical usefulness remains to be assessed $(18,162)$. Inactivation of wild type $\mathrm{p} 53$ by complexing with the cellular proto-oncogene MDM2 could also disrupt p53 function (148). It has also been recently shown that MDM2 enhances proliferation by stimulating the $\mathrm{S}$-phase inducing transcription factor E2F/DP1 (136). Both mechanisms could participate in progression of disease. For bladder cancer it has been shown that MDM2 overexpression is strongly correlated with low-stage, low-grade tumors and that a strong association with p53 overexpression exists. The precise clinical relevance of MDM2 overexpression in bladder cancer remains to be proven (119).

In spite of the positive predictive value of $86 \%$, the occurrence of a p53 mutation is not an absolute sign for progression of disease. Whenever a high karyometric score is observed in a bladder washing of a superficial TCC patient this is an indication for both a careful follow up (at least every three months) and p53 mutation analysis. As a control experiment we also analyzed thirty-five bladder washings with a low karyometric score for the presence of a p53 mutation; in this group no p53 mutations were detected (data not shown). The occurrence of all p53 mutations in the group of patients with a high 2cDI value (abnormal DNA content) suggests a link between p53 dysfunction and genomic instability $(213,229,233)$. The combination of a high karyometric score and a p53 mutation identifies patients with a high probability of progression to invasive disease, within a relatively short time period (approximately 8 months). However, 54\% 
of the high risk patients without a demonstrable p53 mutation progress to invasive disease. Summarizing these data, it is obvious that more prognostic markers are needed to increase not only the positive predictive value but especially the negative predictive value of this screening procedure. Our choice to study p53 mutations by SSCP, does not exclude the usefulness of p53 immunohistochemistry on bladder washings, especially since it is more accessible as a diagnostic tool. We are currently studying the predictive value of $\mathrm{p} 53$ overexpression analyzed by immunohistochemistry in bladder washings for progression of superficial TCC.

In conclusion, for a group of superficial TCC patients indicated to be high risk based on karyometry (228), the occurrence of a p53 mutation has positive predictive value for disease progression. Moreover, since p53 mutations were found in samples prior to documented progression their presence could identify patients who need a change in their treatment strategy in order to prevent progression to invasive disease. The clinical usefulness of $\mathrm{p} 53$ mutations as a marker with additional predictive value should now be assessed in a large prospective study. 


\title{
Chapter 5
}

\section{Comparative analysis of p53 mutations in bladder washings and histological specimens.}

Jacquelıne AM Vet ${ }^{\prime}$, PhD, Daphne Hessels', MS, Salvatore AE, Marras ${ }^{1}$, MS, Chnstına A van de $\mathrm{Kaa}^{2}, \mathrm{MD}$, Henk G van der Poel ${ }^{1}, \mathrm{MD}$, Rob J Michalıdes ${ }^{3}$, PhD, Frans MJ Debruyne ${ }^{1}$, MD, Jack A Schalken', PhD

\begin{abstract}
Bladder washungs have the advantage over histological specimens in that they reflect the general status of the urothelium and since it is a simple outpatient procedure, patients can be monitored more carefully Mutations in the tumor suppressor gene p53, analyzed in bladder washıngs, have been reported to be of significant prognostic value for the progression of superficial bladder cancer to invasive disease To determıne the actual value of bladder washing specimens to assess the p53 status of histological specimens, we analyzed bladder washings and the synchronous tumors of 15 patients for the presence of p53 mutations using Polymerase Chain Reaction-Single Strand Conformation Polymorphism (PCR-SSCP) A significant comelation ( $p<005$, Fischer Exact, two-tall test) between the p53 status of bladder washings and histological specimens was observed if these were compared among the specimens of a single patient Overall, in 2 patients, the mutation present in the tumors was not detected in the bladder washings and in one patient the mutation in the bladder washing was not detected in the histological specimens These conflicting results between bladder washings and histological specimens could partly be explained by the architecture of the tumors The observed specificity of $86 \%$ and sensitivity of $75 \%$ emphasizes that although there is a good correlation between the two methods in a number of cases they are complementary to one another From these findings we conclude that the analysis of p 53 mutations in consecutive bladder washings of a patient does generally reflect the p53 status of the synchronous tumors
\end{abstract}

Departments of Urology' and Pathology ${ }^{2}$, University hospital Nijmegen, Nijmegen and the Department of tumorbiology, The Netherlands Cancer Institute ${ }^{3}$, Amsterdam, The Netherlands This work was supported by grants from the Dutch Cancer Society (NUKC9102 and NUKC9251) Submitted for publication 


\section{Introduction}

Bladder cancer is, with an annual incidence of 20 cases per 100.000 , the fifth most prevalent cancer in the western male population. In women a lower incidence of five cases per 100.00 is observed (173). Superficial TCC, which accounts for $80 \%$ of all newly diagnosed TCCs, in general has a good prognosis. However, $10-25 \%$ of these tumors progress to invasive disease $(74,101)$. To identify patients at risk for progression to invasive disease, reliable prognostic markers are urgently needed.

Multifocal occurrence of bladder tumors is consistent with field disease of the urothelium rather than a focal process. In this respect bladder washings have an advantage over histological biopsies in that they reflect the general status of the entire urothelium of the bladder. In a large prospective study in our hospital, bladder washings were studied by quantitative karyometric analysis in which two nuclear features, 2c Deviation Index and nuclear shape were analyzed (228). This karyometric analysis on exfoliated cells in bladder washings resulted in a substantial increase of the reproducibility and sensitivity of the standard cytological analysis. Moreover, it offers additional prognostic information to classical factors (unpublished observations). In a previous study we attempted to enhance the clinical usefulness of this procedure to predict progression, by adding an additional prognostic marker: the tumor suppressor gene p53. The p53 gene is located on chromosome 17p13.1 and encodes a nuclear phospoprotein involved in the maintenance of DNA integrity and is the most common mutated gene in human malignant tumors $(87,117)$. Our findings indicate that for a group of superficial TCC patients at risk for recurrence as indicated by karyometric analysis (228), the occurrence of a p53 mutation detected in their bladder washings has a positive predictive value of $86 \%$ for the progression to invasive disease (unpublished observations). In order to determine the actual value of bladder washing specimens to asses the p53 status of histological specimens, we analyzed the bladder washings and their synchronous tumors of 15 patients for the presence of p53 mutations. 


\section{Material and Methods}

\section{Specimens}

\section{Histological samples}

Sixteen paraffin-embedded superficial bladder carcinomas (pTa-pT1), three superficial carcinomas with associated carcinoma in situ (CIS), eight muscle-invasive carcinomas ( $\mathrm{TT} \geq 2$ ), two CIS, 3 metastases obtained from 15 patients with high risk superficial TCC were used for PCR-SSCP analysis. All patients were indicated to be at high risk for superficial TCC progression on the basis of quantitative karyometric analysis (228) and as intermediate or high risk by calculating their prognostic index score based on tumor stage, multicentricity, recurrence rate and number of bladder areas involved (101). All patients received optimal intravesical therapy (e.g. Bacillus Calmete-Guerin instillations) as soon as they were found to have a high risk superficial bladder tumor.

For DNA isolation four $20 \mu \mathrm{m}$ sections of paraffin embedded tissue were used. Using an adjacent $5 \mu \mathrm{m} \mathrm{H/E}$ stained section as a guide, the tissue of interest ( $\geq 70 \%$ tumor cells) was dissected from the paraffin section and transferred to an eppendorf tube. Depending on the amount of tissue 100-500 $\mu$ lysis buffer was added. After vortexing the tube was briefly centrifuged. For each $100 \mu$ lysis buffer ( $10 \mathrm{mM}$ TrisHCl pH 8.8, $400 \mathrm{mM} \mathrm{NaCl}$, $2 \mathrm{mM}$ EDTA, $0.45 \%$ Tween $20^{\mathrm{tm}}$ and $0.45 \%$ Nonidet $\left.\mathrm{P} 40\right) 5 \mu \mathrm{l}$ proteinase $\mathrm{K}(10 \mathrm{mg} / \mathrm{ml})$ was added. The tube was gently mixed and incubated for 1 hour at $60^{\circ} \mathrm{C}$.

The proteinase $\mathrm{K}$ was inactivated by boiling for 5 minutes. After brief centrifugation, the DNA suspension was removed from the remaining paraffin and transferred to a new tube. A phenol extraction and an alcohol precipitation were performed and the samples were resuspended in one-half of the original volume. A $2.5-5 \mu l$ aliquot of DNA solution, depending on the original amount of tissue, was subjected to 45 cycles of PCR.

\section{Bladder washing samples}

Twenty-six bladder washing specimens from the same 15 patients were analyzed for $\mathrm{p} 53$ mutations. DNA isolation was performed as described in chapter 4. 


\section{PCR-SSCP and sequences analysis}

PCR-SSCP and sequence analysis were performed as described in chapter 4 .

\section{p53 immunohistochemistry}

Paraffin embedded tissue of 29 bladder tumors and 3 metastases were studied for the occurrence of p53 overexpression. For immunohistochemistry $5 \mu \mathrm{m}$ sections were deparaffinized, rehydrated and covered with citrate buffer $(10 \mathrm{mM}, \mathrm{pH} 6)$ and underwent a microwave-retrieval treatment (setting at $450 \mathrm{~W}$ ) for 15 minutes (75). The slides were then washed twice with PBS, and were rinsed thoroughly with PBS between each of the following steps. The sections were first blocked with undiluted rabbit serum, for 10 minutes at $37^{\circ} \mathrm{C}$. The sections were then incubated overnight with a 1:400 dilution of D0-7 (DAKO) at $4^{\circ} \mathrm{C}$. Subsequently the sections were incubated with biotinylated rabbit anti-mouse (1:1000 in PBS/1\% BSA) (DAKO) for 30 minutes at room temperature. Preformed peroxidase-conjugated streptavidin-biotin complex (DAKO) was then applied for 30 minutes at room temperature, and peroxidase was demonstrated by applying $0.05 \% \quad 3,3^{\prime}$-Diaminobenzidine containing $0.6 \%$ hydrogen peroxide for 5 minutes. The sections were then thoroughly washed in water and nuclei were lightly counterstained with hematoxylin. The pattern of nuclear overexpression was classified in four categories by estimating the percentage of stained tumor cells: -, no positive cells; ,+ 1 to $10 \%$ positive tumor cells;,++ 10 to $50 \%$ positive tumor cells and,$+++>50 \%$ positive tumor cells.

\section{Statistical analysis}

The Chi-square test (with Yates correction if relevant) and the Fischer Exact test were used to demonstrate statistical difference between groups.

\section{Results}

\section{p53 mutations in histological specimens}

Thirty two histological specimens from 15 patients were analyzed by PCR-SSCP. Mutations were found in 7 out of $8(87.5 \%)$ muscle-invasive tumors, 6/21 (28.5\%) superficial tumors (and associated CIS) and in one of the three metastases studied (Table 1). Mutations were found four times in exon 6 and eleven times in exon 8 . 
Table 1. Comparison of p53 mutations analyzed (PCR-SSCP) in bladder washings and concomitant histological specımens.

\begin{tabular}{|c|c|c|c|c|c|c|c|}
\hline \multirow[b]{3}{*}{$\begin{array}{l}\text { Case } \\
\text { no }\end{array}$} & \multicolumn{7}{|c|}{ p53 Alteratıons } \\
\hline & \multicolumn{4}{|c|}{ Histological materıal } & \multicolumn{3}{|r|}{ Bladder washings } \\
\hline & Year & $\begin{array}{l}\text { Stage/ } \\
\text { Grade }\end{array}$ & Mutation & $\begin{array}{l}\text { Immuno- } \\
\text { positivity }\end{array}$ & Year & Mutatıon & Amıno acıd change ${ }^{8}$ \\
\hline 1 & $\begin{array}{l}051290 \\
140292\end{array}$ & $\begin{array}{l}a / 1 \\
2 / 3\end{array}$ & $\begin{array}{l}\text { normal } \\
\text { exon } 8\end{array}$ & $\begin{array}{l}++ \\
++\end{array}$ & $\begin{array}{l}051290 \\
140292\end{array}$ & $\begin{array}{l}\text { exon } 8 \\
\text { exon } 8\end{array}$ & $\begin{array}{l}\text { codon } 285 / \text { GAG } \rightarrow \text { AAG / Glu } \rightarrow \text { Lys } \\
\text { codon } 281 / \text { GAG } \rightarrow \text { GAC / G/u } \rightarrow \text { Asp }\end{array}$ \\
\hline 2 & $\begin{array}{l}091292 \\
160393 \\
101193\end{array}$ & $\begin{array}{r}1 / 3 \\
1 / 2 b \\
1 / 2\end{array}$ & $\begin{array}{l}\text { normal } \\
\text { normal } \\
\text { normal }\end{array}$ & $\begin{array}{l}+ \\
- \\
-\end{array}$ & $\begin{array}{l}011292 \\
160392 \\
210993\end{array}$ & $\begin{array}{l}\text { exon } 5 \\
\text { nd } \\
\text { normal }\end{array}$ & \\
\hline 3 & $\begin{array}{l}181290 \\
081191 \\
311291 \\
150792\end{array}$ & $\begin{array}{r}a / 2 \\
1 / 2 b \\
1 / 3, \mathrm{CIS} \\
\geq 2 / 3\end{array}$ & $\begin{array}{l}\text { normal } \\
\text { normal } \\
\text { exon } 6 \\
\text { exon } 6\end{array}$ & $\begin{array}{l}+ \\
+ \\
+++ \\
+++\end{array}$ & $\begin{array}{l}181290 \\
071191 \\
301291 \\
150792\end{array}$ & $\begin{array}{l}\text { normal } \\
\text { normal } \\
\text { exon } 6 \\
\text { exon } 6\end{array}$ & $\begin{array}{l}\text { codon } 205 / \text { TAT } \rightarrow \text { TGT / Tyr } \rightarrow \text { Lys } \\
\text { codon } 205 / \text { TAT } \rightarrow \text { TGT / Tyr } \rightarrow \text { Lys }\end{array}$ \\
\hline 4 & $\begin{array}{l}221093 \\
090594 \\
090594\end{array}$ & $\begin{array}{r}1 / 3 \\
4 / 3 \\
\text { (meta) }\end{array}$ & $\begin{array}{l}\text { exon } 8 \\
\text { exon } 8 \\
\text { exon } 8\end{array}$ & $\begin{array}{l}++ \\
++ \\
++\end{array}$ & $\begin{array}{l}131093 \\
290394\end{array}$ & $\begin{array}{l}\text { exon } 8 \\
\text { exon } 8\end{array}$ & $\begin{array}{l}\text { codon } 273 / \text { CGT } \rightarrow \text { CAT / Arg } \rightarrow \text { His } \\
\text { codon } 273 / \text { CGT } \rightarrow \text { CAT / Arg } \rightarrow \text { HIS } \\
\text { codon } 273 / \text { CGT } \rightarrow \text { CAT / Arg } \rightarrow \text { HIs }\end{array}$ \\
\hline 5 & 060892 & $4 / 2 b$ & exon $6^{p}$ & - & 011092 & exon $6^{\circ}$ & codon $213 /$ CGA $\rightarrow$ CGG / Arg $\rightarrow$ Arg \\
\hline 6 & $\begin{array}{l}230891 \\
111291\end{array}$ & $\begin{array}{r}\mathrm{CIS} \\
\geq 2 / 3\end{array}$ & $\begin{array}{l}\text { exon } 6 \\
\text { exon } 6\end{array}$ & $\begin{array}{l}++ \\
+\end{array}$ & $\begin{array}{l}230891 \\
101291\end{array}$ & exon 6 & $\begin{array}{l}\text { codon } 194 / \text { CTT } \rightarrow \text { CGT / Leu } \rightarrow \text { Arg } \\
\text { codon } 194 / \text { CTT } \rightarrow \text { CGT / Leu } \rightarrow \text { Arg }\end{array}$ \\
\hline 7 & $\begin{array}{l}021287 \\
270592 \\
150992 \\
301192\end{array}$ & $\begin{array}{r}a / 1 \\
1 / 3 \\
2 / 3 \\
\text { (meta) }\end{array}$ & $\begin{array}{l}\text { exon } 8 \\
\text { exon } 8 \\
\text { exon } 8 \\
\text { normal }\end{array}$ & $\begin{array}{l}- \\
++ \\
++ \\
+\end{array}$ & $\begin{array}{l}\text { nd } \\
200592 \\
140992\end{array}$ & $\begin{array}{l}\text { normal } \\
\text { normal }\end{array}$ & \\
\hline 8 & $\begin{array}{l}281194 \\
020195 \\
020195\end{array}$ & $\begin{array}{r}2 / 3 \\
4 / 3 \\
\text { (meta) }\end{array}$ & $\begin{array}{l}\text { nd } \\
\text { exon } 8 \\
\text { exon } 8 \\
\text { normal }\end{array}$ & $\begin{array}{l}++ \\
+ \\
++\end{array}$ & $\begin{array}{l}180594 \\
161194\end{array}$ & $\begin{array}{l}\text { exon } 8 \\
\text { normal } \\
\text { nd }\end{array}$ & $\begin{array}{l}\text { codon } 280 / \text { AGA } \rightarrow \text { AAA } / \text { Arg } \rightarrow \text { Lys } \\
\text { codon } 280 / A G A \rightarrow \text { AAA } / A r g \rightarrow L y s \\
\text { codon } 280 / \text { AGA } \rightarrow \text { AAA } / A r g \rightarrow L y s\end{array}$ \\
\hline 9 & $\begin{array}{l}260690 \\
040393\end{array}$ & $\begin{array}{r}1 / 3, \mathrm{CIS} \\
\mathrm{CIS}\end{array}$ & $\begin{array}{l}\text { normal } \\
\text { nd } \\
\text { exon } 8 \\
\text { nd }\end{array}$ & $\begin{array}{l}++ \\
++\end{array}$ & $\begin{array}{l}211191 \\
290993\end{array}$ & $\begin{array}{l}\text { nd } \\
\text { normal } \\
\text { nd } \\
\text { exon } 8\end{array}$ & $\begin{array}{l}\text { nd } \\
\text { codon } 280 / \text { AGA } \rightarrow \text { ACA / Arg } \rightarrow \text { Thr }\end{array}$ \\
\hline 10 & $\begin{array}{l}230889 \\
061192\end{array}$ & $\begin{array}{l}a / 2 b \\
a / 2 b\end{array}$ & $\begin{array}{l}\text { normal } \\
\text { normal }\end{array}$ & $\begin{array}{l}++ \\
++\end{array}$ & 211092 & $\begin{array}{l}\text { nd } \\
\text { normal }\end{array}$ & \\
\hline 11 & $\begin{array}{l}270691 \\
100192\end{array}$ & $\begin{array}{l}a / 3 \\
1 / 3\end{array}$ & $\begin{array}{l}\text { normal } \\
\text { normal }\end{array}$ & + & 270691 & $\begin{array}{l}\text { normal } \\
\text { nd }\end{array}$ & \\
\hline 12 & 081093 & $a / 2 b$ & normal & - & 290993 & normal & \\
\hline 13 & 011290 & $a / 2 b$ & normal & - & 011290 & normal & \\
\hline 14 & 061191 & $a / 2 b$ & normal & - & 051191 & normal & \\
\hline 15 & 161091 & $1 / 2 b, \mathrm{CIS}$ & $\begin{array}{l}\text { exon } 8 \\
\text { nd } \\
\text { nd }\end{array}$ & +++ & $\begin{array}{l}151091 \\
221092 \\
190892\end{array}$ & $\begin{array}{l}\text { normal } \\
\text { normal } \\
\text { normal }\end{array}$ & \\
\hline
\end{tabular}

\footnotetext{
A number of positive cells: $\cdot, 0 \% ;+, 1-10 \%,++, 10-50 \% ;+++,>50 \%:^{D}$ polymorphism codon 213 ,

mutations confirmed in both bladder washing and histological specimen (when both specimens were avallable).

- not representative sample, nd, not determıned.
} 
In case \#5 the previously described polymorphism in codon 213 of exon 6 (139) was detected. The identified nucleotide change, i.e. an $A$ to $G$ transversion did not result in an amino acid change (Table 1).

\section{p53 mutations in bladder washings}

Twenty-six bladder washings of 15 patients from this group were compared with the concomitant histological specimens. Mutations were found in 10/26 (38.5\%) bladder washings (Table 1).

Mutations were found once in exon 5 , three times in exon 6 and six times in exon 8 (Table 1). In case \#5 again the known polymorphism in exon 6 was detected (139).

Table 2. Relationship between the overall p53 status of bladaer washings and synchronous histologic specımen summarized for each individual patıent.

\begin{tabular}{lccc}
\hline & Histo / p53mut & Histo / p53wt & Total number \\
\hline BW / p53mut & 6 & 1 & 7 \\
BW / p53wt & 2 & 6 & 8 \\
Total number & 8 & 7 & 15 \\
\hline
\end{tabular}

Histo, hıstological specımen; BW, bladder washıng;

p53mut, mutated p53 gene; p53wt, normal p53 gene.

\section{Comparison p53 mutations in bladder washings and synchronous histological material.}

To investigate the usefulness of bladder washings to determine the p53 status of the synchronous tumors, we compared both specimens for these 15 patients (Table 1).

If the results for each individual patient are summarized, the p53 analysis of the bladder washings and histological specimens showed a significant correlation $(\mathrm{p}<0.05$, Fischer's exact test, two-tail) (Table 2). A specificity of $86 \%(6 / 7)$ and a sensitivity of $75 \%(6 / 8)$ was observed. Overall in two patients (case \#7 and \#15) the mutation found in the histological specimen could not be detected in one of the consecutive bladder washings and in one patient (case \#2) the mutation observed in the bladder washing is not detected in any of the histological specimens analyzed. These conflicting results between histological specimens and bladder washings can partly be explained by the architecture of the tumors as is shown in Figure 1. Both the pT1G3 and the pT2G3 tumor of case \#7 
were covered by normal urothelium, as is clearly illustrated by the immunohistochemical staining of these histological specimens (Figure $1 \mathrm{~A}$ and $1 \mathrm{~B}$ ). In case \#15 the p53 overexpressing cells are present in a CIS lesion that is in contact with the luminal site, but the number of cells is very small (Figure 1C). The concomitant pT1G2b tumor is growing in brunns cell nests (Figure 1D). In two out of the three metastases (case \#7 and $\# 8$ ) the mutation observed in the original tumor is not detected. The relatively small number of p53 overexpressing tumor cells in these metastases is the most likely explanation (Figure 1E). The PCR-SSCP analysis of the other metastasis (case \#4) revealed the same mutation as observed in the original tumor. As is shown in figure $1 \mathrm{~F}$ the relative amount of p53 overexpressing tumor cells in this metastasis is much higher compared to case $\# 7$ and $\# 8$.

Individual comparison of bladder washings and their synchronous histological specimens revealed some additional discrepancies as is shown in Table 1 . In case \#1 the mutation in the first analyzed bladder washing was not found in the concomitant tumor. The next histological specimen, however, revealed a different mutation, that was confirmed in the concomitant bladder washing. In case \#8 a mutation was found in the histological specimen but not in the concomitant bladder washing. However, the same mutation was found in a prior analyzed bladder washing.

\section{p53 immunohistochemistry}

We defined a tumor as $\mathrm{p} 53$ positive if more than $10 \%$ of the tumor cells showed p53 overexpression. A significant correlation between $\mathrm{p} 53$ mutation and $\mathrm{p} 53$ overexpression is observed $(p<0.01$, chi-square $=7.18)$ (Table 1$)$. However, 3 out of 15 tumors $(20 \%)$ with a proven p53 mutation show no p53 overexpression, whereas of the 18 tumors with p53 overexpression 6 tumors (33\%) have no identified p53 mutation.

\section{Comparison specific nature mutations confirmed by sequence analysis}

Sequence analysis revealed 9 transitions and 4 transversions (Table 1). Of the 5 patients of which sequence data were available from both the mutation observed in the bladder washing as well as in the synchronous tumor, 4 showed the same mutation. However, in one patient (case \#1), different mutations were observed in the two bladder washings analyzed. 

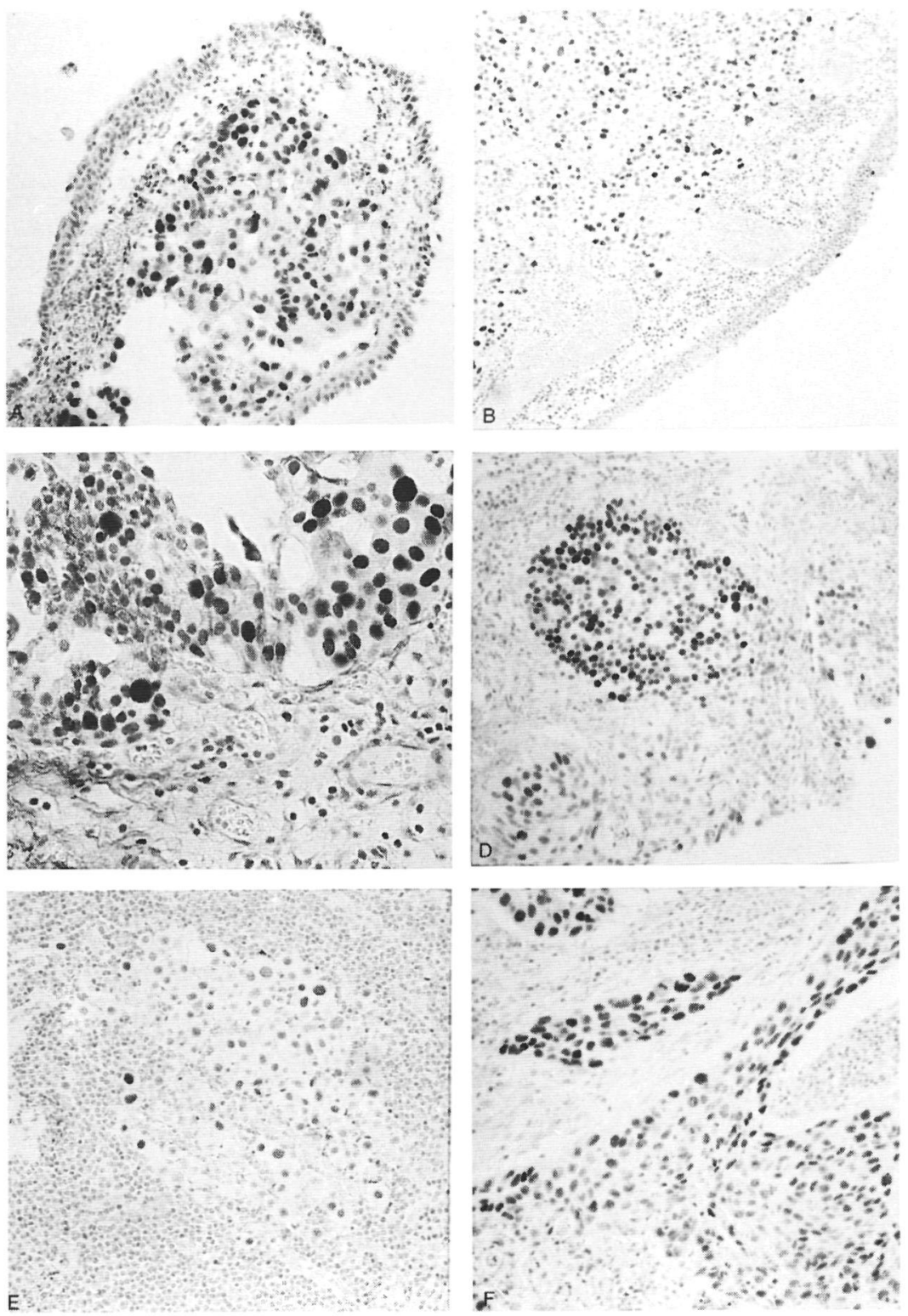

Figure 1: Immunohistochemical staining of p53 expression using p53 DO-7 monoclonal antibody. A. pT1G3 tumor of case \#7; B. pT2G3 tumor of case \#7; C. CIS of case \#15; D. pT1G2b tumor of case \#15; E. lymph-node metastasis of case \#8; F. lymph-node metastasis of case \#4; Original magnification: 100x (B), 200x (A,D,E,F) and 400x (C). 


\section{Discussion}

A significant problem in the management of patients with superficial TCC is the identification of those patients who are at risk for progression to invasive disease. Early identification could make a change in the treatment strategy possible when the disease is still confined to the bladder. In our institution the prognostic index score (based on stage, grade, multicentricity and number of bladder areas involved) (101) and the quantitative karyometric analysis of bladder washings (228) are used as prognostic factors. These markers are useful to stratify patients with superficial TCC into low or high risk categories. However, the morbidity associated with cystectomy, which at the moment is the only treatment to prevent progression to invasive disease, emphasizes the need for additional markers to increase both the specificity and sensitivity of this procedure to predict progression. In a previous study we showed the positive predictive value of p53 mutation analysis in bladder washings for progression of high risk $(101,228)$ superficial TCC (unpublished observations). We chose to use bladder washings, because it is a simple outpatient procedure and patients can be monitored more carefully. Moreover, since bladder cancer is hypothesized to be a field disease of the urothelium, bladder washings have the advantage of reflecting the status of the entire bladder mucosa. The use of bladder washings is preferred over urine specimens, since more representative and better preserved material is harvested $(1,255)$.

PCR-SSCP analysis of the p53 gene in our histological specimens revealed an association of $\mathrm{p} 53$ mutations with invasive tumors as was previously shown $(64,199,233)$. The pre-selected nature of the tumors in this study explains the observed higher percentage p53 mutations in both the superficial as well as the invasive tumors.

The importance of analyzing p53 mutations in bladder washings results from the possibility of preventing disease progression by increased surveillance. The clinical relevance of the analysis is due to the ability to detect a p53 mutation in the bladder washing before progression to invasive disease has occurred and not per se the absolute concordance between the p53 status of each histologic specimen and its paired bladder washing. We found a significant correlation ( $p<0.05$, Fischer Exact test, two-tail) between the p53 status of bladder washings and histological specimens if these were compared among the specinens of a single patient. However some discrepancies were observed. In one patient (case \#2) a mutation was observed in the bladder washing, but 
could not be detected in any of the histological specimens analyzed. The existence of minor lesions that have already acquired the mutant p53 status (207) but were too small to be observed by cystoscopy could explain the presence of mutated p53 cells in these bladder washings. This phenomenon emphasizes the advantage of bladder washings which makes analysis of cells from the entire bladder mucosa possible. In two patients (case \#7 and \#15) the observed mutation in the histological specimen(s) was not detected in any of the bladder washings analyzed. The absence of mutated cells in the bladder washings of patient $\# 7$ could be explained by the histologic composition of the tumors. Both tumors were clearly covered by 'normal' (no p53 overexpression) urothelium which most likely prevented the release of mutated p53 tumor cells into the bladder washing. Although the clear presence of CIS in patient \#15 (all of the cells showed p53 overexpression) would predict that mutated cells should be present in the bladder washing, most likely the number of cells was too small to detect the mutation. The concomitant $\mathrm{pT} 1 \mathrm{G} 2 \mathrm{~b}$ tumor is growing in brunns cell nests, preventing the major part of the 553 overexpressing cells from releasing in the bladder washing.

Individual comparison of the synchronous bladder washings and histological specimens showed some additional discrepancies. In one patient (case \#8) the mutation detected in the histological specimen (pT2G3) was not found in the concurrent bladder washing, but was observed in a previous bladder washing. The invasive nature of the tumor could have prevented the release of the mutated cells into the bladder washing. In one patient (case \#1) a mutation was observed in the bladder washing but could not be detected in the synchronous tumor. The subsequently resected tumor (14 months later), showed a mutation. This mutation however differed from the first observed mutation in the bladder washing, but was identical to the mutation found in the concomitant bladder washing. This occurrence of different p53 gene mutations in bladder tumors of one patient has also been reported in two TCC patients in a previous study (207). The other four patients showed identical p53 mutations in the consecutive bladder washings and the synchronous tumors, which is in agreement with the theory of the clonal origin of bladder tumors (200).

PCR-SSCP analysis using histologic specimens can despite microdissection of tumor give false-negative results caused by the presence of a relatively high percentage of normal cells as is shown in this study, by the high number of lymphocytes in two of the three metastases analyzed (247). Although the good concordance between p53 mutations 
and p53 overexpression, in a substantial number of tumors discrepancies are observed, which is in agreement with previous studies $(81,234,249)$.

In conclusion, in two patients, the mutation present in the tumors was not detected in the bladder washings and in one patient the mutation in the bladder washing was not detected in the histologic specimens. The observed specificity of $86 \%$ and sensitivity of $75 \%$ emphasizes that although there is a good correlation between the two methods in a number of cases they are complementary to one another. More regular examination of bladder washings for the presence of a p53 mutation could lead to early identification of patients who need a change in their treatment strategy (conservative to radical) and thereby potentially prevent disease progression.

From these findings we conclude that the analysis of $\mathrm{p} 53$ mutations in consecutive bladder washings of a patient does generally reflect the p53 status of the synchronous tumors. We are currently assessing the clinical usefulness of p53 mutation analysis in bladder washings as a prognostic marker in a prospective study.

\section{Acknowledgment}

We would like to thank Mrs. Petra Kristel, Mrs. Anita Gemmink and Mr. Coos Diepenbrock for excellent technical assistance. 


\title{
Chapter 6
}

\section{Differential expression of ferritin Heavy chain in a rat Transitional Cell Carcinoma progression model.}

Jacquelıne A M Vet, Reındert J A van Moorselaar, Frans M J Debruyne, and Jack A Schalken ${ }^{1}$

\begin{abstract}
To identify molecular markers with predictive value for the progression of superficial bladder cancer we used the differential hybndization analysis approach Since pnmary tumor matenal is heterogeneously composed of subpopulations that are poorly characterized, we used in this study a rat progression model system that phenotypically and cytogenetically resembles human superficial bladder cancer In the differential hybndization analysis we compared the mRNA populations of low and high metastatic tumor lines We observed an overexpression of ferntin Heavy chain (ferntin H) in the tumor line with the lower metastatic capacity and better differentiated phenotype The exact clinical relevance for the differential expression of femtin $\mathrm{H}$ in human bladder cancer remains to be determıned
\end{abstract}

Department of Urology, University Hospital Nijmegen, P O Box 9101, 6500 HB Nijmegen, The Netherlands This work was financially supported by a grant from the Dutch Cancer Society (NUKC9102). Submitted for publication 


\section{Introduction}

An important issue in the management of superficial transitional cell carcinoma (TCC) of the bladder is to identify those patients that are at risk for progression to invasive disease. Since primary tumor material is usually heterogeneously composed of subpopulations that are poorly characterized, it is not suitable to identify TCC progression markers. The identification of such parameters requires a tumor model system in which the different stages of tumor progression are represented.

In this study a rat bladder tumor model system (RBT) is used that phenotypically and cytogenetically resembles human superficial TCC (230). In order to identify genes that are associated with the progression of superficial bladder cancer we applied the technique of differential hybridization analysis to compare the mRNA levels of the RBT 323 with the RBT 157 line, two lines that differ in their metastatic capacity. Both tumor lines initially resembled grade 2 TCC. However, while the histological pattern of the RBT 157 remained essentially unchanged, the RBT 323 tumor progressed to a grade 3 tumor in the third passage. The cDNA clones that detected differentially expressed genes were further evaluated for their relationship to the metastatic phenotype by means of Northern blot analyses of all the passages of the rat TCC progression model. The cDNA clones of interest were sequenced and the resulting nucleotide sequences were compared to nucleotide database to search for homology with known genes.

\section{Materials and methods}

\section{Tumor specimens}

Tumor material from a rat bladder tumor model system (RBT) (230) was used in this study (Table 1). Transplant passage \#10 of the highly metastatic line RBT 323 and passage \#1 of the moderate metastatic line RBT 157 were used for the differential hybridization experiments. In order to check the relevance of the selected clones passages $1,2,8,9,15$ and 16 of the RBT 323 line and passage 1 through 6 of the RBT 157 line were used. 
Table 1. Growth characteristics of rat bladder tumor lines.

\begin{tabular}{llrr}
\hline & Tumor passage & Tumor doublıng tıme & Metastases $^{\mathbf{A}}$ \\
\hline RBT323 & & ND & $0 / 1$ \\
& Passage 1 & ND & $0 / 6$ \\
& Passage 2 & $13.4(1.4)$ & $0 / 8$ \\
& Passage 3 & $11.8(1.2)$ & $1 / 10$ \\
& Passage 4 & $5.9(1.0)$ & $0 / 9$ \\
& Passage 5 & $5.7(0.3)$ & $3 / 7$ \\
& Passage 6 & $4.4(0.1)$ & $11 / 13$ \\
& Passage 8 & $3.8(0.2)$ & $15 / 15$ \\
& Passage 10 & $3.7(0.2)$ & $9 / 9$ \\
& Passage 12 & $4.2(0.3)$ & $19 / 22$ \\
& Passage 13 & $3.3(0.3)$ & $6 / 6$ \\
RBT157 & Passage 15 & $4.3(0.3)$ & $5 / 6$ \\
& & ND & $0 / 1$ \\
& Passage 1 & $11.2(0.8)$ & $0 / 4$ \\
& Passage 2 & ND & $1 / 7$ \\
& Passage 3 & $10.5(1.1)$ & $2 / 9$ \\
& Passage 4 & $8.2(0.3)$ & $5 / 8$ \\
& Passage 6 & $9.5(1.8)$ & $2 / 6$ \\
\hline
\end{tabular}

${ }^{A}$ Tumor doublıng tıme in days, standard error of the mean in brackets. ${ }^{B}$ Number of rats with lung metastases/total number of rats implanted with respective tumor passage. ND, not determined. [RJA van Moorselaar et al.(230)]

\section{Construction of cDNA libraries}

A directionally cloned cDNA library was constructed using polyadenylated cytoplasmic RNA from the highly metastatic RBT323 line, passage \#10. Poly(A+)-RNA (5 $\mu$ g) was fractionated from total RNA by oligo(dT)-cellulose chromatography and total RNA was isolated using the lithium chloride/urea procedure (4). First strand cDNA was synthesized by using an oligo(dT) primer-adaptor (Promega) containing a NOT-1 site $5^{\prime}$ to the oligo(dT) tail. Second strand cDNA synthesis was performed using the procedures described by Gubler and Hofman (76). The cDNA was blunt ended by using T4-DNA polymerase (10 U). After purification using micro collodion bags (Sartorius $\mathrm{GmbH}$ ), EcoR 1 linkers ( $1 \mu \mathrm{g}$, Stratagene) were ligated to the blunt ended cDNA by means of T4DNA ligase, followed by digestion with NOT-1 and Eco-RI restriction endonucleases. The digested linkers were separated from the cDNA by means of PurElute ${ }^{\mathrm{lm}}$ agarose gel electrophoresis (Invitrogen) and the cDNAs with the desired size range (0.5-10 kB) were 
isolated from the agarose. Electroelution of the cDNA from the agarose was performed using the Geneluter ${ }^{\mathrm{tm}}$ electroelution system (Invitrogen). Subsequently the ds cDNA was ligated in the Lambda Zap-II cloning vector (Stratagene), inserted into the phage particles using Promega Packagene Lambda DNA Packaging System and transformed to XL-1 Blue E. coli bacteria.

\section{Differential screening of the cDNA library}

For the differential screening of the RBT 323/10 cDNA library, 36.000 recombinant phages were plated. After ovemight incubation, 4 replicas of each plate were taken on nitrocellulose by incubation during $1,3,10$ and 30 minutes respectively. The filters were next lysed according to Sambrook et al. (176). Hybridization was performed according to Hanahan and Meselson (82) in $40 \%$ formamide at $42^{\circ} \mathrm{C}$ during 60 hours. For the differential screening, probes representative for the RBT 323/pass.10 and RBT 157/pass.1 mRNA populations were prepared by random prime labeling (53) of first strand cDNA. For hybridization of the filters, $1.10^{6} \mathrm{dpm} / \mathrm{ml}$ hybridization solution was used. The replica's 1 and 10 minutes were hybridized with probe derived from the RBT 157/pass. 1 and the replica's 3 and 30 minutes were hybridized with probe derived from the RBT 323/pass.10. The blots were washed according to Hanahan and Meselson (82). The filters were exposed for autoradiography during three days. Extensive comparison of the autoradiograms resulted in selection of differentially expressed clones.

\section{Phagemid isolation}

Putative differential expressed cDNA clones were purified and phagemids were isolated according to the Stratagene protocol.

\section{Northern blot analysis.}

For the northern blot analysis, 10 micrograms of total RNA was glyoxylated, size fractionated on $1 \%$ agarose gels and transferred to Hybond-N+ nylon membranes (Amersham). Probes were made of the differentially expressed cDNA clones, obtained from small scale plasmid isolations or of purified inserts of the cDNA clones, by random prime labeling reactions (53). Hybridization experiments were performed according to Church and Gilbert (30). 
Sequence analysis and computer analysis

Sequence analysis was performed with the Sequenase Version 2.0 System (United States Biochemical). M13 and reverse primers were used allowing sequence analysis from both ends of the clones. Computer assisted comparison studies of the sequences were performed with the EMBL and Genbank nucleotide sequence databases.

\section{Results}

\section{Differential screening}

A cDNA library was constructed from the mRNA of the highly metastatic line RBT 323 passage 10 . The complexity of the library was $4.3 \times 10^{5}$ recombinant clones and 36.000 recombinant phages from the primary library were plated. Replica filters were differentially screened using radioactively labeled cDNA probes derived from poly$A^{+}$RNA of the RBT 323/pass.10 (high metastatic) and the RBT 157/pass.1 (low metastatic).

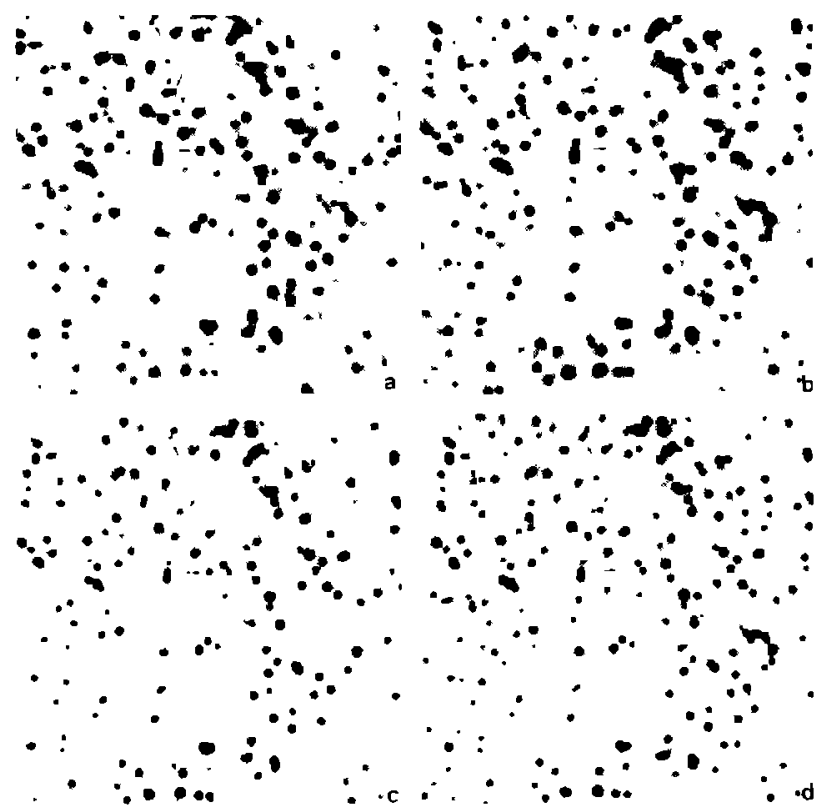

Figure 1. Differentıal screening of the RBT 323/10 cDNA library. Replicas were hybridized to cDNA probes prepared using poly- ${ }^{+}$-RNA from the RBT $157 / 1$ line $(A+C)$ or from the RBT 323/10 line $(B+D)$. 
Extensive comparison of the resulting autoradiograms (Figure 1) revealed 22 cDNA clones that seemed to be differentially expressed; 16 overexpressed in the RBT 323 line and 6 overexpressed in the RBT 157 line. These 22 selected cDNA clones were further evaluated using Northern blots containing $10 \mu \mathrm{g}$ of RBT 157/1, RBT 323/1 and RBT $323 / 10$ RNA. The expression patterns of the most significant clones are shown in Figure 2.
pV11
$\mathrm{pV} 13$
pV16
pV19

MW (kb)

$\begin{array}{llllllllllll}1 & 2 & 3 & 1 & 2 & 3 & 1 & 2 & 3 & 1 & 2 & 3\end{array}$

6.7.

4.3.
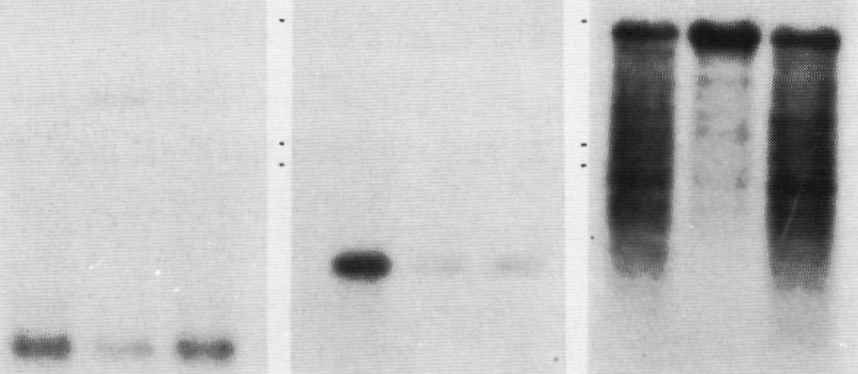

Figure 2. Secondary screening of the selected cDNA clones on the passages RBT 157/1 (1), RBT $323 / 1$ (2) and RBT $323 / 10$ (3). $10 \mu \mathrm{g}$ of total RNA was glyoxylated, size fractionated on $1 \%$ agarose gels and transferred to Hybond- $\mathrm{N}+$ nylon membranes. Probes were made of the differentially expressed cDNA clones by random prime labeling reactions

\section{Expression pattern of $\mathrm{pV} 13$}

Clone pV13, is clearly overexpressed in RBT $157 / 1$, the line with the lowest metastatic capacity. pV13 detects a single transcript of approximately $1.1 \mathrm{~Kb}$ (Figure 2). The correlation of clone pV13 expression with metastatic capacity was further studied by means of Northern blot analysis of all passages of the rat progression model (Figure 3). The RBT 157 line, with the moderate metastatic capacity, shows an higher expression level compared to the RBT 323 line, with the high metastatic capacity. The right panel of figure 3 illustrates that the higher expression is retained in all the passages of RBT 157. The other clones did not retain a significant differential expression on further evaluation or appeared to originate from ribosomal RNA. 
Chapter 6

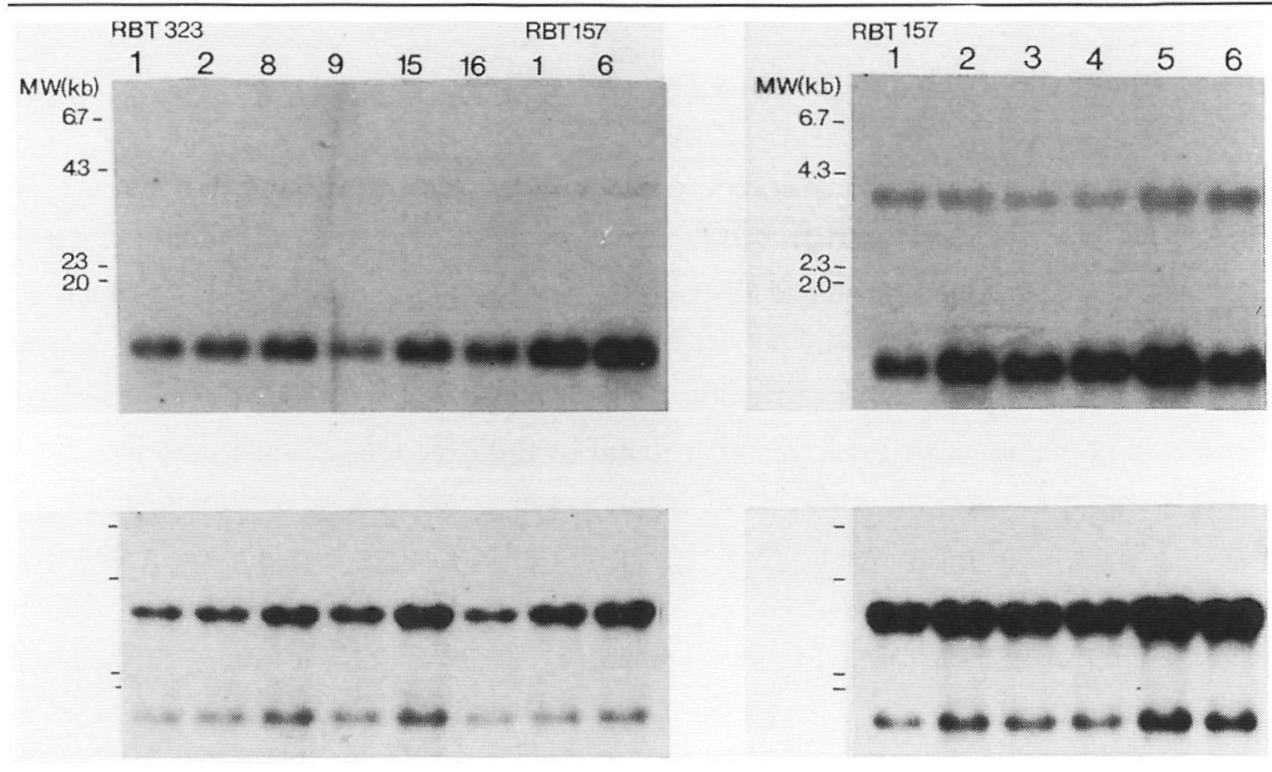

Figure 3. Correlation of clone $\mathrm{pV} 13$ with metastatic phenotype. $10 \mu \mathrm{g}$ of total RNA was glyoxylated, size fractionated on $1 \%$ agarose gels and transferred to Hybond- $\mathrm{N}+$ nylon membranes. The probe was made, using the isolated insert of cDNA clone pV13, by random labeling reaction

\section{DNA sequence analysis of pV13}

To obtain further information on the cDNA clone, the nucleotide sequences were determined using the Sequenase Version 2.0 sequence system. Computer-assisted comparison of the resulting nucleotide sequences with the EMBL and Gen bank nucleotide sequence databases revealed that pV13 is highly homologous to the Rat Ferritin Heavy chain gene (97\%) (151) and the Mouse Ferritin Heavy chain (94\%) (217). 


\section{Discussion}

In search of new molecular markers with predictive value for the progression of superficial TCC, we compared two different tumor lines of a rat TCC model system at the level of gene expression using differential hybndization analysis We observed an overexpression of ferntin $\mathrm{H}$ in the RBT 157 tumor line which displays the lowest metastatic capacity and the best differentiated phenotype

Ferritin $H$ combines with the ferritin L subunit to form the iron storage protein ferritın (143) Ferritin H-rich molecules take up and release iron more readily than L-rich molecules, that are more suited for long-term storage (150) A relationship between ferritin and cancer has been proposed, since serum ferritin is frequently elevated in patients with cancer $(48,246)$ Some neoplastic cells also exhibit a remarkably altered ferritin subunit composition (1 e enrichment for the heavy chain subunit) as compared to their normal counterparts $(24,232)$ A direct association between oncogenic transformation and ferritin synthesis has been suggested, since the adenovirus ElA oncogene specifically represses ferritin $H$ expression (223) The observed downregulation of ferritin $\mathrm{H}$ expression in the more malignant tumor line RBT 323 is in concordance with this observation The correlation between ferritin $\mathrm{H}$ expression and a number of differentiation processes shown by others $(9,27)$, is corroborated in this study by the overexpression of ferritin $\mathrm{H}$ in the better differentiated tumor line RBT 157 In smooth muscle cells it is proposed that cAMP promotes ferritin $\mathrm{H}$ expression resulting in both growth arrest and an enhanced differentiated phenotype (123)

The exact biological consequences of altered ferritin subunit composition are not well understood It may result in modulation of the iron binding capacity of ferritin and ultımately, the regulatory pools of free iron $(143,222)$ An enrichment for the ferritin $H$ subunit leads to more efficient iron detoxification and cellular protection against free radical formation (179)

It should be emphasized that the mechanisms underlying the altered subunit composition of ferritin in neoplastic cells are not elucidated Ferntin $\mathrm{H}$ is located on chromosome 11 (86), near l lq13 (67), a region that is sometimes amplified in bladder cancer (171) We have determıned that the ferritin $\mathrm{H}$ gene is not within the amplicon on 11 q13 (data not shown) 
We are currently investigating the value of this differential expression of ferritin $\mathrm{H}$ as a prognostic marker in human bladder cancer using quantitative comparative Polymerase Chain Reaction. 
Chapter 7

Summary and general discussion 
A significant problem in the clinical management of transitional cell carcinoma of the bladder (TCC) is the identification of those patients that are at risk for progression of their disease. In addition to the "classic" histopathologic diagnosis and clinical parameters, new markers identifying patients at risk for tumor progression are urgently needed. The advances in the molecular approach to tumor biology of the last years resulted in a better understanding of cancer genetics and new potential prognostic markers. This thesis describes two approaches to evaluate molecular prognostic markers: (i) the major part focuses on the prognostic value of the known tumor suppressor gene p53 and its significance as a diagnostic tool, (ii) the use of differential hybridization analysis as a method to identify new molecular prognostic factors.

Alterations of p53 can be identified directly at the genetic level, by detecting mutations in the p53 gene using Polymerase Chain Reaction-Single Strand Conformation Polymorphism (PCR-SSCP) analysis or indirectly by the detection of p53 protein overexpression using immunohistochemistry (IHC). These two methods were compared in chapter 2 to assess their reliability. Although a good concordance $(p<0.02)$ between p53 mutation by SSCP analysis and p53 overexpression by IHC was observed, in a substantial number of tumors discrepancies were found. Two out of eight tumors with a SSCP proven p53 mutation showed no p53 immunoreactivity at all, most likely as a result of loss of the nuclear localization signal. In addition to these "false negatives", p53 overexpression was observed in $23 \%$ of the tumors without any sign of p53 mutation as assessed by SSCP analysis. Therefore, despite the tight correlation between p53 mutation and p53 overexpression, there is no direct causal relationship between mutation and overexpression. Apparently other events than mutation can trigger p53 stability. Additional research is necessary to characterize these events and to understand the mechanisms through which this overexpression without a concomitant mutation reflects alteration of $\mathrm{p} 53$ function and consequently gives rise to an altered phenotype in cancer cells.

Clinical parameters were compared with p53 overexpression (IHC) and p53 mutation (PCR-SSCP) (Chapter 2 and 3). A significant correlation between p53 alteration and grade as well as stage was observed ( $p<0.05$ vs. IHC and $p<0.001$ vs. SSCP, respectively). Moreover, $\mathrm{p} 53$ alteration is an unfavorable prognostic factor for the whole group of bladder cancer patients ( $p<0.01$ vs. IHC and $p<0.001$ vs. SSCP, respectively). No association between $\mathrm{p} 53$ alteration and decreased survival was found for invasive 
tumors. The immunohistochemical results for invasive TCC are in contrast with other studies. Differences in treatment of patients, antibody, methodology and scoring systems used might explain these differences. However, a recent study has shown that p53 overexpression is a significant predictor of tumor progression for the group of muscleinvasive tumors, only when the disease is confined to the bladder ( $\mathrm{pT} \leq 3 \mathrm{a})$. With more extensive disease ( $\mathrm{p} T \geq 3 \mathrm{~b}$ ), p53 overexpression has no additional prognostic value. Because of the relatively small number of invasive tumors in our study, we could not compare these two groups. In superficial TCC a trend was observed towards poorer survival for the patients showing p53 overexpression. No p53 mutations were observed in this group of superficial tumors. This difference stresses again the discordance of p53 immunohistochemistry and $\mathrm{p} 53$ mutation analysis.

In chapter 3 also the association between p 53 mutations and frequency of allelic loss, as a putative indicator of genetic instability, was investigated. A high frequency of allelic loss was found in tumors with a p53 mutation, suggesting a correlation with genetic instability, which could be explained by an altered G1-S cell cycle checkpoint, resulting from the loss of wild type p53 function.

It is critically important to define if, and when p53 mutations occur during tumor progression from superficial (Ta) tumors to lamina propria invasive (Tl) tumors and muscle invasive (T2-T4) tumors. To assess the value of p53 mutations in predicting the progression of superficial TCC, consecutive bladder washings from high risk superficial TCC patients (indicated by quantitative karyometric analysis) were examined (Chapter 4). We chose for direct analysis of mutations because of the more objective nature of this method compared to IHC. Bladder washings have the advantage over histological biopsies in that they reflect the general status of the bladder mucosa since cells from the entire bladder are sampled. Moreover, this is a simple outpatient procedure and patients can be monitored more frequently. Six out of 13 patients that clinically progressed (to $\mathrm{pT} \geq 2$ ) showed a p53 mutation in one or more of their bladder washings prior to progression. In the control group (no progression) only one out of 13 patients showed a p53 mutation. In high risk patients, as indicated by quantitative karyometric analysis, the occurrence of a p53 mutation has a positive predictive value for progression to invasive disease of $86 \%$. The low negative predictive value $(63 \%)$ implicates that, although a p53 mutation indicates a malignant potential for the tumor, the absence of a p53 mutation does not guarantee a good prognosis. Since p 53 mutations were found in samples prior 
to documented progression their presence could identify patients who need a change in their treatment strategy to potentially prevent progression to invasive disease. The clinical usefulness of p53 mutation analysis as a diagnostic tool should now be assessed in a large prospective study.

Chapter 5 describes the comparative p53 mutation analysis of bladder washings and their synchronous tumors to determine the actual value of bladder washings to assess the p53 status of the histological specimens. A significant correlation between the p53 status of bladder washings and histological specimens was observed if these were compared among the specimens of a single patient ( $p<0.05$ ). Overall, in two patients ( 2 out of 15 ) the mutation present in the tumors was not detected in the bladder washings and in one additional patient the mutation in the bladder washing was not detected in the histological specimens. These conflicting results between bladder washings and histological specimens could partly be explained by the architecture of the tumors. This study shows that the analysis of p53 mutations in consecutive bladder washings of a patient does generally reflect the p53 status of the synchronous tumors. As addressed earlier, washing of the bladder is a simple outpatient procedure, whereby monitoring of patients on more frequent basis is possible. This could lead to an increased detection of TCC patients at high risk for progression and thereby potentially prevent this progression to invasive disease.

In addition to the study of the prognostic value of the known tumor suppressor gene p53, we used differential hybridization analysis to identify new molecular markers that are associated with the progression of superficial bladder cancer (Chapter 6). Primary tumor material is usually composed of subpopulations with different malignant potential and is therefore not suitable to identify TCC progression markers. In this study a rat bladder tumor model system was used, that phenotypically and cytogenetically resembles human superficial TCC. The mRNA populations of low and high metastatic tumor lines were compared. Ferritin Heavy $(H)$ chain was identified to be overexpressed in the tumor line with lowest metastatic capacity and a more differentiated phenotype. Ferritin $\mathrm{H}$ combines with the ferritin light subunit to form the iron storage protein ferritin. A relationship between ferritin and cancer has been proposed and some neoplastic cells exhibit a remarkably altered ferritin subunit composition compared to their normal counterparts. The overexpression of ferritin $\mathrm{H}$ in the more differentiated tumor line is a corroboration of the observed association between ferritin $\mathrm{H}$ and a 
number of differentiation processes. The observed lower expression of ferritin $\mathrm{H}$ in the more malignant tumor line is in concordance with the observation that during oncogenic transformation, the adenovirus E1A oncogene specifically represses ferritin $H$ expression. Since we used a rat bladder tumor model system for the differential hybridization experiments, the value of the differential expression of ferritin $\mathrm{H}$ as a prognostic marker in the human system remains to be elucidated.

The studies described in this thesis emphasize that alterations in the tumor suppressor gene p53 are important in the clinical behavior of bladder tumors. Although a good overall concordance between p53 gene mutation and p53 protein overexpression in relation with grade, stage and survival exists, there is no direct causal relationship between mutation and protein overexpression. In the group of high risk superficial TCC patients, identified by quantitative karyometric analysis, the occurrence of a p53 mutation as examined in bladder washings, appears to be of value as an additional marker to predict progression to invasive disease. In spite of these promising results, it is obvious that more prognostic markers are needed to increase not only the positive predictive value, but especially the negative predictive value of this screening procedure. The technique of differential display could be useful as a tool to identify new prognostic markers, provided that the compared mRNA populations are very precisely defined. Good candidates for the panel of prognostic markers that are available at this moment, are Epidermal Growth Factor Receptor and E-cadherin. Together with the "classic" histopathologic diagnosis and clinical parameters this panel of prognostic markers should be evaluated in a large prospective study, with well defined patient populations and standardized technical procedures to assess their exact clinical relevance. 


\section{References}

1 Aamodt RL, Coo JS, Deitch A, deVere White RW, Koss LG, Melamed MR, Weinstein RS, Wheeless LL Flow cytometric evaluation of bladder cancer recommendations of the $\mathrm{NCI}$ flow cytometry network for bladder cancer World J Urol 10, 63-67, 1992

2 Allred DC, Clark GM, Elledge R, Fuqua SA, Brown RW, Chamness GC, Osborne CK, McGurre WL Association of p53 protein expression with tumor cell prolıferation rate and clinical outcome in node-negative breast cancer [see comments] J Natl Cancer Inst 85 200-206, 1993

3 Atkın NB, Baker MC Cytogenetic study of ten carcinomas of the bladder involvement of chromosomes 1 and 11 Cancer Genet Cytogenet 15 253-268, 1985

4 Auffray C, Rougeon F Purification of mouse immunoglobulin heavy-chain messenger RNAs from total myeloma tumor RNA Eur J Brochem 107 303-314, 1980

5 Baas IO, Mulder JW, Offerhaus GJ, Vogelsteın B, Hamılton SR An evaluatıon of six antıbodıes for immunohıstochemıstry of mutant $\mathrm{p} 53$ gene product in archıval colorectal neoplasms $J$ Pathol $172 \quad 5-12,1994$

6 Baker SJ, Fearon ER, Nigro JM, Hamılton SR, Preisinger AC, Jessup JM, vanTunen P, Ledbetter DH, Barker DF, Nakamura Y, et al Chromosome 17 deletions and p53 gene mutations in colorectal carcinomas Science 244 217-221, 1989

7 Barnes DM, Hanby AM, Gillett CE, Mohammed S, Hodgson S, Bobrow LG, Leigh IM, Purkıs T, MacGeoch C, Spurr NK, et al Abnormal expression of wild type p53 protein in normal cells of a cancer family patient Lancet 340 259-263, 1992

8 Basset P, Bellocq JP, Wolf C, Stoll I, Hutın P, Limacher JM, Podhajcer OL, Chenard MP, Rıo MC, Chambon $\mathrm{P}$ A novel metalloprotenase gene specifically expressed in stromal cells of breast carcinomas Nature 348 699-704, 1990

9 Beaumont C, Jain SK, Bogard M, Nordmann Y, Drysdale J Ferritın synthesıs in differentiating Friend erythroleukemic cells J Bıol Chem 262 10619-10623, 1987

10 Behrens J, Mareel MM, Van Roy FM, Birchmeier W Dissecting tumor cell invasion eptthehal cells acquire invasive properties after the loss of uvomorulın-mediated cell-cell adhesion $J$ Cell Bıl 108 2435-2447, 1989

11 Benchımol S, Lamb P, Crawford LV, Sheer D, Shows TB, Bruns GA, Peacock J Transformation associated p53 protein is encoded by a gene on human chromosome 17 Somat Cell Mol Genet 11 $505-510,1985$

12 Berger CS, Sandberg AA, Todd IA, Pennington RD, Haddad FS, Hecht BK, Hecht F Chromosomes in kıdney, ureter, and bladder cancer Cancer Genet Cytogenet 23 1-24, 1986

13 Berger MS, Greenfield C, Gullıck WJ, Haley J, Downward J, Neal DE, Harrı AL, Waterfield MD Evaluation of epidermal growth factor receptors in bladder tumours $\mathrm{Br} J$ Cancer 56 533-537, 1987 
14 Blomjous CE, Schıpper NW, Baak JP, van Galen EM, de Voogt HJ, Meyer CJ Retrospectıve study of prognostic importance of DNA flow cytometry of urınary bladder carcinoma $J$ Clin Pathol 41 $21-25,1988$

15 Bockıng A, Chatelain R Diagnostıc and prognostıc value of DNA cytometry in gynecologic cytology Anal Quant Cytol Histol 11 177-186, 1989

16 Bomer MM, Myers CE, Sartor O, Se1 Y, Toko T, Trepel JB, Schnejder E Drug-ınduced apoptosis is not necessarily dependent on macromolecular synthesis or proliferation in the p53-negative human prostate cancer cell line PC-3 Cancer Res 55 2122-2128, 1995

17 Brewster SF, Gingell JC, Browne S, Brown KW Loss of heterozygosity on chromosome 18q is associated with muscle-invasive transitional cell carcinoma of the bladder $\mathrm{Br} J$ Cancer 70 $697-700,1994$

18 Brınguier PP, Umbas R, Schaafsma HE, Karthaus HF, Debruyne FM, Schalken JA Decreased E-cadherin immunoreactivity correlates with poor survival in patients with bladder tumors Cancer Res 53 3241-3245, 1993

19 Bufton L, Mohandas TK, Magenıs RE, Sheehy R, Bestwick RK, Litt M A highly polymorphic locus on chromosome $16 \mathrm{q}$ revealed by a probe from a chromosome-specific cosmid library Hum Genet 74 425-431, 1986

20 Burchıll SA, Neal DE, Lunec J Frequency of H-ras mutatıons in human bladder cancer detected by direct sequencıng BrJ Urol 73 516-521, 1994

21 Caelles C, Helmberg A, Karın M p53-dependent apoptosıs in the absence of transcriptıonal activation of p53-target genes [see comments] Nature 370 220-223, 1994

22 Caims P, Proctor AJ, Knowles MA Loss of heterozygosity at the RB locus is frequent and correlates with muscle invasion in bladder carcinoma Oncogene 6 2305-2309, 1991

23 Caıms P, Tokıno K, Eby Y, Sıdransky D Homozygous deletıons of 9p21 in primary human bladder tumors detected by comparative multıplex polymerase chaın reaction Cancer Res 54 1422-1424, 1994

24 Caıro G, Vezzonı P, Bardella L, Schıaffonatı L, Rappocciolo E, Levı S, Arosıo P, Bemellı Zazzera A Regulation of ferritın synthesis in malignant and non-malignant lymphoid cells Biochem Biophys Res Commun 139 652-657, 1986

25 Call KM, Glaser T, Ito CY, Buckler AJ, Pelletıer J, Haber DA, Rose EA, Kral A, Yeger H, Lewis $\mathrm{WH}$, et al Isolation and characterization of a zinc finger polypeptide gene at the human chromosome 11 Wilms' tumor locus Cell 60 509-520, 1990

26 Cesarman E, Inghıramı G, Chadburn A, Knowles DM High levels of p53 proteın expression do not correlate with $\mathrm{p} 53$ gene mutations in anaplastıc large cell lymphoma $\mathrm{Am} J$ Pathol $143845-$ 856,1993

27 Chazenbalk GD, Wadsworth HL, Rapoport B Transcriptional regulation of ferritın $\mathrm{H}$ messenger RNA levels in FRTL5 rat thyroıd cells by thyrotropın $J$ Bıol Chem 265 666-670, 1990

28 Chen X, Farmer G, Zhu H, Prywes R, Prives C Cooperatıve DNA binding of p53 with TFIID (TBP) a possible mechanism for transcriptional actıvation [published erratum appears in Genes Dev 1993 Dec,7(12B) 2652] Genes Dev 7 1837-1849, 1993 
29 Chin Л, Huben RP, Nava E, Rustum YM, Greco JM, Pontes JE, Frankfurt OS Flow cytometric analysis of DNA content in human bladder tumors and irrigation fluids Cancer 56 1677-1681, 1985

30 Church GM, Gilbert W Genomic sequencing Proc Natl Acad Scı U S A 81 1991-1995, 1984

31 Condıe A, Eeles R, Borresen AL, Coles C, Cooper C, Prosser J Detection of point mutations in the p53 gene comparison of single-strand conformation polymorphism, constant denaturant gel electrophoresıs, and hydroxylamıne and osmium tetroxıde technıques Hum Mutat 2 58-66, 1993

32 Coombs LM, Pigott DA, Sweeney E, Proctor AJ, Eydmann ME, Parkınson C, Knowles MA Amplification and over-expression of c-erbB-2 in transitional cell carcinoma of the urinary bladder Br J Cancer 63 601-608, 1991

33 Cordon Cardo C, Wartınger D, Petrylak D, Dalbagnı G, Faır WR, Fuks Z, Reuter VE Altered expression of the retınoblastoma gene product prognostic indicator in bladder cancer [see comments] J Natl Cancer Inst 84 1251-1256, 1992

34 Cordon Cardo C, Dalbagnı G, Saez GT, Olıva MR, Zhang ZF, Rosal J, Reuter VE, Pellıcer A p53 mutations in human bladder cancer genotypic versus phenotypic patterns $I n t J$ Cancer 56 $347-353,1994$

35 Czemiak B, Deitch D, Simmons H, Etkınd P, Herz F, Koss LG Ha-ras gene codon 12 mutation and DNA ploidy in urinary bladder carcinoma $B r J$ Cancer 62 762-763, 1990

36 Dalbagnı G, Prestı J, Reuter V, Farr WR, Cordon Cardo C Genetıc alterations in bladder cancer [see comments] Lancet 342 469-47I, 1993

37 De Bolla AR, Shave RM, Fagg SL, Heald K, Hughes MA, Wallace DM, Edwards PD The influence of retınoic acid receptor (RAR) status of bladder tumours on the course of the disease $\mathrm{Br}$ JUrol 57 676-679, 1985

38 De Winter GA, Coebergh JWW, van Leeuwen FE, Schouten LJ eds Incidence of cancer in the Netherlands, 1989 First report of the Netherlands cancer registry Utrecht LOK, 1992

39 Demers GW, Foster SA, Halbert CL, Galloway DA Growth arrest by induction of p53 in DNA damaged keratınocytes is bypassed by human papillomavirus 16 E7 Proc Nall Acad Scl US A 91 4382-4386, 1994

40 DeVere White RW, Deitch AD, West B, Fitzpatrick JM The predictive value of flow cytometric information in the clinical management of stage $O$ (Ta) bladder cancer J Urol 139 279-282, 1988

41 Devlın J, Keen AJ, Knowles MA Homozygous deletion mapping at 9p21 in bladder carcinoma defines a critical region within 2cM of IFNA Oncogene 9 2757-2760, 1994

42 Devonec M, Hijazı A A new concept in the natural history of human bladder cancer based on genetıc instabılity as evidence by flow cytometric DNA analysıs In Burger G, Ploem JS, Goerttler K (eds) Clinical cytometry and histometry Academic Press, London, 441-446, 1987

43 Donehower LA, Harvey M, Slagle BL, McArthur MJ, Montgomery CA,Jr, Butel JS, Bradley A Mice deficient for p53 are developmentally normal but susceptible to spontaneous tumours Nature $356215-221,1992$ 
44 EI Deıry WS, Kem SE, Pıetenpol JA, Kınzler KW, Vogelsteın B Definıtıon of a consensus bındıng site for p53 Nat Genet 1 45-49, 1992

45 El Deıry WS, Tokıno T, Velculescu VE, Levy DB, Parsons R, Trent JM, Lın D, Mercer WE, Kinzler KW, Vogelsiein B WAF1, a potential mediator of p53 tumor suppression Cell 75 $817-825,1993$

46 Esrıg D, Spruck CH, Nıchols PW, Chaıwun B, Steven K, Groshen S, Chen SC, Skınner DG, Jones PA, Cote RJ p53 nuclear protein accumulation correlates with mutations in the p53 gene, tumor grade, and stage in bladder cancer Am J Pathol 143 1389-1397, 1993

47 Esrıg D, Elmajıan D, Groshen S, Freeman JA, Steın JP, Chen SC, Nichols PW, Skınner DG, Jones PA, Cote RJ Accumulation of nuclear p53 and tumor progression in bladder cancer $N$ Engl $J$ Med 331 1259-1264, 1994

48 Essen A, Ozen H, Ayhan A, Ergen A, Tasar C, Remzı F Serum ferrıtın a tumor marker for renal cell carcinoma $J$ Urol 145 1134-1137, 1991

49 Farmer G, Bargonettı J, Zhu H, Frıedman P, Prywes R, Prives C Wild-type p53 actıvates transcription in vitro [see comments] Nature 358 83-86, 1992

S0 Fearon ER, Cho KR, Nigro JM, Kem SE, Simons JW, Ruppert JM, Hamılton SR, Preısınger AC, Thomas G, Kinzler KW, et al Identification of a chromosome 18q gene that is altered in colorectal cancers Science 247 49-56, 1990

51 Fearon ER, Feınberg AP, Hamılton SH, Vogelstein B Loss of genes on the short arm of chromosome 11 in bladder cancer Nature 318 377-380, 1985

52 Fearon ER, Vogelsteın B A genetıc model for colorectal tumorigenesis Cell 61 759-767, 1990

53 Feınberg AP, Vogelsteın B A technıque for radıolabelıng DNA restriction endonuclease fragments to high specific activity Anal Blochem 132 6-13, 1983

54 Fields S, Jang SK Presence of a potent transcription activatıng sequence in the p53 protein Science 249 1046-1049, 1990

55 Finlay CA, Hinds PW, Tan TH, Elıyahu D, Oren M, Levıne AJ Actıvatıng mutatıons for transformation by $\mathrm{p} 53$ produce a gene product that forms an hsc 70 -p 53 complex with an altered half-lıfe Mol Cell Brol 8 531-539, 1988

56 Fisher DE Apoptosis in cancer therapy crossing the threshold Cell 78 539-542, 1994

57 Fitzgerald JM, Ramchurren N, Rıeger K, Levesque P, Sılverman M, Libertıno JA, Summerhayes IC Identıfication of $\mathrm{H}$-ras mutations in urıne sediments complements cytology in the detection of bladder tumors J Nall Cancer Inst 87 129-133, 1995

58 Fossa SD, Bemer AA, Jacobsen AB, Waehre H, Kvarsteın B, Umes T, Ogreıd P, Johansen TE, Silde J, Nesland JM, et al Clinical significance of DNA ploidy and S-phase fraction and theır relation to 53 proteın, c-erbB-2 proteın and HCG in operable muscle-ınvasıve bladder cancer $\mathrm{Br} J$ Cancer 68 572-578, 1993

59 Fradet Y, Islam N, Boucher L, Parent Vaugeoıs C, Tardıf M Polymorphic expressıon of a human superficıal bladder tumor antıgen defined by mouse monoclonal antibodies Proc Natl Acad Scı US A 84 7227-7231, 1987 
60 Fradet $\mathrm{Y}$, Tardif M, Bourget L, Robert J Clinical cancer progression in urinary bladder tumors evaluated by multiparameter flow cytometry with monoclonal antibodies Laval University Urology Group Cancer Res 50 432-437, 1990

61 Fradet Y, Lafleur L, LaRue H Strategies of chemoprevention based on antigenic and molecular markers of early and premalignant lesions of the bladder JCell Blochem Suppl 16I 85-92, 1992

62 Fradet $\mathrm{Y}$, Cordon Cardo C Critıcal appraisal of tumor markers in bladder cancer Semin Urol 11 145-153, 1993

63 Frixen UH, Behrens J, Sachs M, Eberle G, Voss B, Warda A, Lochner D, Birchmeier W E-cadherın-mediated cell-cell adhesion prevents invasıveness of human carcinoma cells $J \mathrm{Ce} / \mathrm{Biol}$ 113 173-185, 1991

64 Fujımoto K, Yamada Y, Okajıma E, Kakızoe T, Sasakı H, Sugımura T, Terada M Frequent association of p53 gene mutation in invasive bladder cancer Cancer Res 52 1393-1398, 1992

65 Furuya Y, Lin XS, Walsh JC, Nelson WG, Isaacs JT Androgen ablation-ınduced programmed death of prostatic glandular cells does not involve recruitment into a defective cell cycle or p53 Induction Endocrinology 136 1898-1906, 1995

66 Gardiner RA, Walsh MD, Allen V, Rahman S, Samaratunga ML, Seymour GJ, Lavın MF Immunohistological expression of p53 in primary pT1 transitional cell bladder cancer in relation to tumour progression $\mathrm{Br} J$ Urol 73 526-532, 1994

67 Gattı RA, Shaked R, Mohandas TK, Salser W Human ferrıtın genes chromosomal assıgnments and polymorphisms Am J Hum Gened 41 654-667, 1987

68 Geradts J, Hu SX, Lincoln CE, Benedict WF, Xu HJ Aberrant RB gene expression in routınely processed, archival tumor tıssues determıned by three different antı-RB antıbodies Int $J$ Cancer 58 $161-167,1994$

69 Giarettı W, Santı L Tumor progression by DNA flow cytometry in human colorectal cancer Int $J$ Cancer 45 597-603, 1990

70 Gibas Z, Prout GR, Connolly JG, Pontes JE, Sandberg AA Nonrandom chromosomal changes in transitional cell carcinoma of the bladder Cancer Res 44 1257-1264, 1984

71 Gibas Z, Prout GR, Pontes JE, Connolly JG, Sandberg AA A possible specific chromosome change In transitional cell carcinoma of the bladder Cancer Genet Cytogenet 19 229-238, 1986

72 Goodrich DW, Wang NP, Qıan YW, Lee EY, Lee WH The retınoblastoma gene product regulates progression through the Gl phase of the cell cycle Cell 67 293-302, 1991

73 Goodrich DW, Chen Y, Scully P, Lee WH Expression of the retinoblastoma gene product in bladder carcinoma cells associates with a low frequency of tumor formation Cancer Res 52 1968-1973, 1992

74 Green LF, Mulcahy JJ, Waren MM Benıgn papilloma or paillary carcinoma of the bladder $J$ Urol $110205-207,1973$

75 Greenwell A, Foley JF, Maronpot RR An enhancement method for immunohistochemical staining of prolıferatıng cell nuclear antıgen in archıval rodent tıssues Cancer Letters 59 251-256, 1991 
76 Gubler U, Hoffman BJ A simple and very efficient method for generatıng cDNA libraries Gene $25 \quad 263-269,1983$

77 Habuchı T, Ogawa O, Kakehı Y, Ogura K, Koshıba M, Hamazakı S, Takahashı R, Sugıyama T, Yoshida O Accumulated allelıc losses in the development of invasive urothelial cancer Int $J$ Cancer 53 579-584, 1993

78 Habuchı T, Kınoshıta H, Yamada H, Kakehı Y, Ogawa O, Wu WJ, Takahashı R, Sugıyama T, Yoshida $O$ Oncogene amplification in urothelial cancers with $p 53$ gene mutation or MDM2 amphification [see comments] $J$ Natl Cancer Inst 86 1331-1335, 1994

79 Hadjıssotırıou GG, Green DK, Smıth G, McIntyre MA, Hargreave TB, Chısholm GD Bladder cancer flow cytometry profiles in relation to histological grade and stage $B r J$ Urol 60 239-247, 1987

80 Hall PA, McKee PH, Menage HD, Dover R, Lane DP High levels of p53 protein in UVırradıated normal human skın Oncogene 8 203-207, 1993

81 Hall PA, Lane DP p53 in tumour pathology can we trust immunohistochemıstry?--Revisited' [editorial] J Pathol $172 \quad 1-4,1994$

82 Hanahan D, Meselson M Plasmid screening at high colony density Gene 10 63-67, 1980

83 Harper JW, Adamı GR, We1 N, Keyomarsı K, Elledge SJ The p21 Cdk-interactıng protein Cipl is a potent inhıbıtor of $\mathrm{Gl}$ cyclın-dependent kınases Cell 75 805-816, 1993

84 Harrıs CC, Hollsteın M Clinıcal implicatıons of the p53 tumor-suppressor gene [see comments] $N$ Engl J Med 329 1318-1327, 1993

85 Hartge P, Silverman D, Hoover R, Schairer C, Altman R, Austın D, Cantor K, Chıld M, Key C, Marrett LD, et al Changing cigarette habits and bladder cancer risk a case-control study $J$ Natl Cancer Inst 78 1119-1125, 1987

86 Hentze MW, Keım S, Papadopoulos P, O'Brıen S, Modı W, Drysdale J, Leonard WJ, Harford JB, Klausner RD Cloning, characterization, expression, and chromosomal localization of a human ferritin heavy-chain gene Proc Natl Acad ScI USA 83 7226-7230, 1986

87 Hollsteın M, Sidransky D, Vogelstein B, Harrı CC p53 mutatıons in human cancers Science 253 49-53, 1991

88 Hopman AH, Ramaekers FC, Raap AK, Beck JL, Devilee P, van der Ploeg M, Vooujs GP In situ hybridization as a tool to study numerical chromosome aberrations in solid bladder tumors Hislochemistry 89 307-316, 1988

89 Hopman AH, Poddighe PJ, Smeets AW, Moesker O, Beck JL, Vooıss GP, Ramaekers FC Detection of numerical chromosome aberrations in bladder cancer by in situ hybridization $\mathrm{Am} \mathrm{J}$ Pathol 135 1105-1117, 1989

90 Hopman AH, Moesker O, Smeets AW, Pauwels RP, Vooljs GP, Ramaekers FC Numerical chromosome 1, 7, 9, and 11 aberrations in bladder cancer detected by in situ hybridization Cancer Res 51 644-651, 1991

91 Horowitz JM, Yandell DW, Park SH, Canning S, Whyte P, Buchkovich K, Harlow E, Weinberg RA, Dryja TP Point mutational inactıvation of the retınoblastoma antıncogene Science 243 937-940, 1989 
92 Horowitz JM, Park SH, Bogenmann E, Cheng JC, Yandell DW, Kaye FJ, Minna JD, Dryja TP, Weinberg RA Frequent inactivation of the retınoblastoma anti-oncogene is restricted to a subset of human tumor cells Proc Natl Acad Scl US A 87 2775-2779, 1990

93 Hruban RH, van der Riet P, Erozan YS, Sidransky D Brief report molecular biology and the early detection of carcinoma of the bladder--the case of Hubert H Humphrey N Engl J Med 330 1276-1278, 1994

94 Hunter T Braking the cycle Cell 75 839-841, 1993

95 Ishıkawa J, Xu HJ, Hu SX, Yandell DW, Maeda S, Kamıdono S, Benedıct WF, Takahashı R Inactivation of the retınoblastoma gene in human bladder and renal cell carcinomas Cancer Res 51 $5736-5743,1991$

96 Joseph A, Weiss GH, Jin L, Fuchs A, Chowdhury S, O'Shaugnessy P, Goldberg ID, Rosen EM Expression of scatter factor in human bladder carcinoma J Natl Cancer Inst 87 372-377, 1995

97 Kallıoniemı A, Kallıonıemı OP, Sudar D, Rutovitz D, Gray JW, Waldman F, Pınkel D Comparative genomic hybridization for molecular cytogenetic analysis of solid tumors Scrence 258 818-821, 1992

98 Kallınıemı A, Kallınıemı O-P, Citro G, Sauter G, DeV rıes S, Kerschmann R, Caroll P, Waldman $F$ Identification of gaıns and losses of DNA sequences in primary bladder cancer by comparatıve genomic hybridization Genes, Chromosomes \& Cancer 12 213-219, 1995

99 Kastan MB, Onyekwere O, Sidransky D, Vogelstein B, Craıg RW Particıpatıon of p53 proteın in the cellular response to DNA damage Cancer Res 51 6304-6311, 1991

100 Keen AJ, Knowles MA Definition of two regions of deletıon on chromosome 9 in carcinoma of the bladder Oncogene 9 2083-2088, 1994

101 Kiemeney LA, Witjes JA, Heijbroek RP, Verbeek AL, Debruyne FM Predictability of recurrent and progressive disease in individual patients with primary superficial bladder cancer $J$ Urol 150 60-64, 1993

102 Kıemeney LA, Witjes JA, Verbeek AL, Heıbroek RP, Debruyne FM The clinical epıdemıology of superficial bladder cancer Dutch South-East Cooperative Urological Group $B r J$ Cancer 67 806-812, 1993

103 Knowles MA, Shaw ME, Proctor AJ Deletion mapping of chromosome 8 in cancers of the urinary bladder using restriction fragment length polymorphisms and microsatellite polymorphisms Oncogene 8 1357-1364, 1993

104 Knowles MA, Williamson M Mutation of H-ras is infrequent in bladder cancer confirmation by single-strand conformation polymorphism analysıs, designed restriction fragment length polymorphisms, and direct sequencing Cancer Res 53 133-139, 1993

105 Knowles MA, Elder PA, Willaamson M, Cairns JP, Shaw ME, Law MG Allelotype of human bladder cancer Cancer Res 54 531-538, 1994

106 Koss LG, Czernak B, Herz F, Wersto RP Flow cytometric measurements of DNA and other cell components in human tumors a critical appraisal Hum Pathol 20 528-548, 1989 
107 Koufos A, Grundy P, Morgan K, Aleck KA, Hadro T, Lampkın BC, Kalbakıı A, Cavenee WK Famılial Wiedemann-Beckwith syndrome and a second Wilms tumor locus both map to 11 pl5 5 Am J Hum Genet 44 711-719, 1989

108 Kurth K, Denis L, Sylvester R, de Pauw M The natural history and the prognosis of treated superficial bladder cancer EORTC GU Group Prog Clin Bıol Res 378 1-7, 1992

109 Kusukawa N, Uemorı T, Asada K, Kato I Rapıd and reliable protocol for direct sequencing of material amplified by the polymerase chain reaction Brotechniques $966-8,70,72,1990$

110 Lane DP, Crawford LV T antigen is bound to a host protein in SV40-transformed cells Nature $278261-263,1979$

111 Lane DP Cancer p53, guardian of the genome [news, comment] [see comments] Nature 358 15-16, 1992

112 Lane DP The regulation of p53 function Steiner Award Lecture Int J Cancer 57 623-627, 1994

113 Latıf F, Tory K, Gnarra J, Yao M, Duh FM, Orcutt ML, Stackhouse T, Kuzmın I, Modı W, Geıl L Identification of the von Hippel-Lindau disease tumor suppressor gene Comment in Science 2601235,1993

114 Lee SE, Chow NH, Chı YC, Tzaı TS, Yang WH, Lın SN Expression of c-erbB-2 proteın in normal and neoplastic urothelium lack of adverse prognostic effect in human urinary bladder cancer Anticancer Res 14 1317-1324, 1994

115 Lee WH, Shew JY, Hong FD, Sery TW, Donoso LA, Young LJ, Bookstein R, Lee EY The retınoblastoma susceptıbılity gene encodes a nuclear phosphoprotein associated with DNA bınding activity Nature $329642-645,1987$

116 Levesque P, Ramchurren N, Saını K, Joyce A, Lıbertıno J, Summerhayes IC Screenıng of human bladder tumors and urıne sedıments for the presence of H-ras mutations Int J Cancer 55 785-790, 1993

117 Levine AJ, Momand J, Finlay CA The p53 tumour suppressor gene Nature 351 453-456, 1991

118 L1 R, Waga S, Hannon GJ, Beach D, Stıllman B Differentıal effects by the p21 CDK inhibitor on PCNA-dependent DNA replication and repair Nature 371 534-537, 1994

119 Lianes P, Orlow I, Zhang ZF, Oliva MR, Sarkıs AS, Reuter VE, Cordon Cardo C Altered patterns of MDM2 and TP53 expression in human bladder cancer [see comments] $J$ Natl Cancer Inst 86 1325-1330, 1994

120 Llang P, Averboukh L, Keyomarsı K, Sager R, Pardee AB Differential display and cloning of messenger RNAs from human breast cancer versus mammary epithelial cells Cancer Res 52 6966-6968, 1992

121 Liang P, Pardee AB Differential display of eukaryotic messenger RNA by means of the polymerase chain reaction Sctence 257 967-971, 1992

122 Liang P, Averboukh L, Pardee AB Distribution and cloning of eukaryotic mRNAs by means of differentıal display refinements and optımızatıon Nucleic Acids Res 21 3269-3275, 1993 
123 Liau G, Chan LM, Feng P. Increased ferritin gene expression is both promoted by cAMP and a marker of growth arrest in rabbit vascular smooth muscle cells $J$ Btol Chem 266: 18819-18826, 1991

124. Linzer DI, Levine AJ. Characterization of a $54 \mathrm{~K}$ dalton cellular SV40 tumor antigen present in SV40-transformed cells and uninfected embryonal carcinoma cells. Cell 17: 43-52, 1979.

125. Lipponen P. Expression of c-erbB-2 oncoprotein in transitional cell bladder cancer. Eur J Cancer 29A $749-753,1993$.

126. Lipponen PK. Over-expression of p53 nuclear oncoprotein in transitional-cell bladder cancer and its prognostic value. Int $J$ Cancer 53: 365-370, 1993.

127. Lipponen P, Eskelinen M. Expression of epidermal growth factor receptor in bladder cancer as related to established prognostic factors, oncoprotein (c-erbB-2, p53) expression and long-term prognosis. Br J Cancer 69: 1120-1125, 1994.

128. Lipponen PK, Liukkonen TJ. Reduced expression of retinoblastoma ( $\mathrm{Rb}$ ) gene protein is related to cell proliferation and prognosis in transitional-cell bladder cancer. $J$ Cancer Res Clin Oncol 121. 44-50, 1995

129. Livingstone LR, White A, Sprouse J, Livanos E, Jacks T, Tlsty TD. Altered cell cycle arrest and gene amplıfication potential accompany loss of wild-type p53. Cell 70: 923-935, 1992.

130. Logothetis CJ, Xu HJ, Ro JY, Hu SX, Sahin A, Ordonez N, Benedict WF. Altered expression of retinoblastoma protein and known prognostic variables in locally advanced bladder cancer [see comments]. J Natl Cancer Inst 84: 1256-1261, 1992.

131. Lönn U, Lonn S, Nylen U, Friberg S, Stenkvist B. Gene amplificatıon detected in carcinoma cells from human urinary bladder washings by the polymerase chain reaction method Cancer 71: 3605-3610, 1993.

132. Lowe SW, Ruley HE, Jacks T, Housman DE. p53-dependent apoptosis modulates the cytotoxicity of anticancer agents. Cell 74. 957-967, 1993.

133 Lowe SW, Bodis S, McClatchey A, Remington L, Ruley HE, Fisher DE, Housman DE, Jacks T. p53 status and the efficacy of cancer therapy in vivo. Scıence 266.807-810, 1994.

134. Mack DH, Vartikar J, Pipas JM, Laimins LA. Specific repression of TATA-mediated but not initiator-mediated transcription by wild-type p53. Nature 363: 281-283, 1993.

135. Mansouri A, Spurr N, Goodfellow PN, Kemler R. Characterization and chromosomal localization of the gene encoding the human cell adhesion molecule uvomorulin. Differentıatıon 38: $67-71,1988$.

136. Martin K, Trouche D, Hagemeier C, Sorensen TS, La Thangue NB, Kouzarides T. Stimulation of E2F1/DP1 transcriptional activity by MDM2 oncoprotein. Nature 375: 691-694, 1995.

137 Matsushima AY, Cesarman E, Chadburn A, Knowles DM. Post-thymic T cell lymphomas frequently overexpress $\mathrm{p} 53$ protein but infrequently exhibit p53 gene mutations. Am J Pathol $144 \cdot 573-584,1994$.

138. Mattei MG, de The H, Mattei JF, Marchio A, Tiollais P, Dejean A. Assignment of the human hap retınoic acid receptor RAR beta gene to the p24 band of chromosome 3. Hum Genet 80: 189-190, 1988 . 
139 Mazars GR, Jeanteur P, Lynch HT, Lenoir G, Theıllet C Nucleotıde sequence polymorphısm in a hotspot mutation region of the p53 gene Oncogene 7 781-782, 1992

140 Messing EM, Bubbers JE, Dekemion JB, Fahey Л Growth stımulating actıvity produced by human bladder cancer cells $J$ Urol 132 1230-1234, 1984

141 Messing EM, Hanson P, Ulrıch P, Erturk E Epidermal growth factor--ınteractions with normal and malıgnant urothelıum in vivo and in situ studies $J$ Urol 138 1329-1335, 1987

142 Mietz JA, Unger T, Hubregtse JM, Howley PM The transcriptional transactivation function of wild-type p53 is inhibited by SV40 large T-antigen and by HPV-16 E6 oncoprotein EMBO J 11 S013-5020, 1992

143 Miller LL, Miller SC, Tortı SV, Tsujı Y, Tortı FM Iron-independent induction of ferritın H chain by tumor necrosis factor Proc Nall Acad Scı US A 88 4946-4950, 1991

144 Miller SA, Dykes DD, Polesky HF A sımple salting out procedure for extractıng DNA from human nucleated cells Nucletc Acıds Res $16 \quad 1215,1988$

145 Miyamoto H, Shuin T, Torıgoe S, Iwasakı Y, Kubota Y Retınoblastoma gene mutations in primary human bladder cancer $\mathrm{Br} J$ Cancer 71 831-835, 1995

146 Mıyao N, Tsaı YC, Lemer SP, Olumı AF, Spruck CH, Gonzalez Zulueta M, Nıchols PW, Skınner DG, Jones PA Role of chromosome 9 in human bladder cancer Cancer Res 53 4066-4070, 1993

147 Miyashita T, Reed JC Tumor suppressor p53 is a direct transcriptional activator of the human bax gene Cell 80 293-299, 1995

148 Momand J, Zambettı GP, Olson DC, George D, Levine AJ The mdm-2 oncogene product forms a complex with the p53 protein and inhibits p53-mediated transactivation Cell 69 1237-1245, 1992

149 Mostofi FK, sobın LH, Torlını H Histological typing of urınary bladder tumors World Health Organisation, Geneva, Switzerland 1973

150 Munro HN, Azız N, Leıbold EA, Murray M, Rogers J, Vass JK, White K The ferritın genes structure, expression, and regulation $A n n N$ Y Acad Sct 526 113-123, 1988

151 Murray MT, White K, Munro HN Conservation of ferritın heavy subunit gene structure implications for the regulation of ferritın gene expression Proc Natl Acad Sci USA 847438 7442,1987

152 Nakamura Y, Fujımoto E, O'Connell P, Leppert M, Lathrop GM, Lalouel JM, White R Isolatıon and mapping of a polymorphic DNA sequence pEFD126 3 on chromosome 9q (D9S7) Nucleic Acuds Res 15 106-107, 1987

153 Neal DE, Marsh C, Bennett MK, Abel PD, Hall RR, Sainsbury JR, Hamis AL Epidermal-growth-factor receptors in human bladder cancer comparison of invasive and superficial tumours Lancet 1 366-368, 1985

154 Neal DE, Sharples L, Smith K, Fennelly J, Hall RR, Harris AL The epidermal growth factor receptor and the prognosis of bladder cancer Cancer 65 1619.1625, 1990

155 Neal DE, Mellon K Epidermal growth factor receptor and bladder cancer a review Urol Int 48 365-371, 1992 
156 Noda A, Ning Y, Venable SF, Pereıra Smith OM, Smıth JR Cloning of senescent cell-derıved inhibitors of DNA synthesis using an expression screen Exp Cell Res 211 90-98, 1994

157 Okamoto $\mathrm{K}$, Beach D Cyclın $\mathrm{G}$ is a transcriptional target of the p53 tumor suppressor protein EMBOJ $13 \quad 4816-4822,1994$

158 Oltva ZN, Millıman CL, Korsmeyer SJ Bcl-2 heterodımerizes in vivo with a conserved homolog, Bax, that accelerates programmed cell death Cell 74 609-619, 1993

159 Olumı AF, Tsai YC, Nichols PW, Skinner DG, Cain DR, Bender LI, Jones PA Allelic loss of chromosome 17p distınguishes high grade from low grade transitional cell carcinomas of the bladder Cancer Res 50 7081-7083, 1990

160 Orıta M, Suzukı Y, Sekıya T, Hayashı K Rapıd and sensitıve detection of point mutations and DNA polymorphısms using the polymerase chaın reaction Genomics 5 874-879, 1989

161 Orlow I, Lianes P, Lacombe L, Dalbagnı G, Reuter VE, Cordon Cardo C Chromosome 9 allelıc losses and microsatellite alterations in human bladder tumors Cancer Res 54 2848-2851, 1994

162 Otto T, Birchmeier W, Schmidt U, Hinke A, Schıpper J, Rubben H, Raz A Inverse relation of E-cadherın and autocrine motılity factor receptor expression as a prognostıc factor in patients with bladder carcinomas Cancer Res 54 3120-3123, 1994

163 Oyasu R, Nan L, Szumel RC, Kawamata H, Hırohashı S p53 gene mutatıons in human urothelıal carcınomas analysis by immunohıstochemıstry and single-strand conformation polymorphism Mod Pathol 8 170-176, 1995

164 Papanıcolaou GN, Marshall VF Unine sedıment smears as a diagnostıc procedure in cancers of the urimary tract Science $101519-520,1945$

I65 Parada LF, Tabın CJ, Shıh C, Weinberg RA Human EJ bladder carcinoma oncogene is homologue of Harvey sarcoma virus ras gene Nature $297474-478,1982$

166 Pietenpol JA, Vogelstein B Tumour suppressor genes No room at the p53 inn [news, comment] Nature 365 17-18, 1993

167 Poddıghe PJ, Brınguier PP, Valınga M, Schalken JA, Ramaekers FC, Hopman AH Comparıson of interphase cytogenetics and RFLP analysis of transitıonal cell carcinoma of the urinary bladder Submitted 1995

168 Poddıghe PP, Bringuier PP, Valınga M, Schalken JA, Raemakers FCS, Hopman AHN Loss of chromosome 9 in tissue sections of transitional cell carcinomas as detected by interphase cytogenetics $J$ Pathol, in press

169 Prestı JC, Jr, Reuter VE, Galan T, Faır WR, Cordon Cardo C Molecular genetıc alteratıons in superficial and locally advanced human bladder cancer Cancer Res 51 5405-5409, 199]

170 Prives C How loops, beta sheets, and alpha helices help us to understand p53 Cell 78 543-546, 1994

171 Proctor AJ, Coombs LM, Cairns JP, Knowles MA Amplification at chromosome $1 / q 13$ in transitional cell tumours of the bladder Oncogene 6 789-795, 1991 
172 Pulcıanı S, Santos E, Lauver AV, Long LK, Robbıns KC, Barbacıd M Oncogenes in human tumor cell lines molecular clonıng of a transformıng gene from human bladder carcinoma cells Proc Natl Acad Scı USA 79 2845-2849, 1982

173 Raghavan D, Shıpley WU, Gamıck MB, Russell PJ, Rıchıe JP Bıology and management of bladder cancer [see comments] $N$ Engl J Med 322 1129-1138, 1990

174 Ravery V, Colombel M, Popov Z, Bastuıı S, Patard JJ, Bellot J, Abbou CC, Fradet Y, Chopın DK Prognostıc value of epıdermal growth factor-receptor, T138 and T43 expression in bladder cancer BrJ Cancer 71 196-200, 1995

175 Ruppert JM, Tokıno K, Sidransky D Evidence for two bladder cancer suppressor locı on human chromosome 9 Cancer Res 53 5093-5095, 1993

176 Sambrook J, Fritsch EF, Maniatıs T Nolan C, ed Molecular Cloning A laboratory manual 2nd ed Cold Spring Harbor Laboratory Press 1989

177 Sanches Y, Elledge SJ Stopped for repairs BıoEsscoys 17 545-548, 1995

178 Sandberg AA, Berger CS, Haddad FS, Kerr D, Hecht F Chromosome change in transitıonal cell carcınoma of ureter Cancer Genet Cytogenet 19 335-340, 1986

179 Santambrogıo P, Levı S, Cozzı A, Rovida E, Albertını A, Arosıo P Production and characterization of recombinant heteropolymers of human ferritın $\mathrm{H}$ and $\mathrm{L}$ chains $J$ Brol Chem 268 12744-12748, 1993

180 Sargent TD Isolation of differentially expressed genes In Methods in Enzymology 152, Berger SL, Kımmel AR (eds) Academic Press, New York, 423-432, 1987

181 Sarkıs AS, Dalbagnı G, Cordon Cardo C, Zhang ZF, Sheınfeld J, Faır WR, Her HW, Reuter VE Nuclear overexpression of $\mathrm{p} 53$ protein in transitional cell bladder carcinoma a marker for disease progression J Natl Cancer Inst 85 53-59, 1993

182 Sarkıs AS, Dalbagnı G, Cordon Cardo C, Melamed J, Zhang ZF, Sheınfeld J, Faır WR, Herr HW, Reuter VE Association of P53 nuclear overexpression and tumor progression in carcinoma in situ of the bladder $J$ Urol $152388-392,1994$

183 Sarkıs AS, Bajorın DF, Reuter VE, Herr HW, Netto G, Zhang ZF, Schultz PK, Cordon Cardo C, Scher HI Prognostic value of p53 nuclear overexpression in patients with invasive bladder cancer treated with neoadjuvant MVAC JClin Oncol 13 1384-1390, 1995

184 Samow P, Ho YS, Willams J, Levine AJ Adenovirus Elb-58kd tumor antigen and SV40 large tumor antigen are physically associated with the same $54 \mathrm{kd}$ cellular protein in transformed cells Cell 28 387-394, 1982

185 Sato K, Morıyama M, Morı S, Saıto M, Watanukı T, Terada K, Okuhara E, Akıyama T, Toyoshıma $\mathrm{K}$, Yamamoto $\mathrm{T}$, et al An immunohıstologic evaluatıon of C-erbB-2 gene product in patıents with urinary bladder carcınoma Cancer 70 2493-2498, 1992

186 Sauter G, Moch H, Moore D, Carroll P, Kerschmann R, Chew K, Mihatsch MJ, Gudat F, Waldman F Heterogeneity of erbB-2 gene amplification in bladder cancer Cancer Res 53 2199-2203, 1993

187 Sauter G, Haley J, Chew K, Kerschmann R, Moore D, Carroll P, Moch H, Gudat F, Mihatsch MJ Waldman $F$ Epidermal-growth-factor-receptor expression is associated with rapid tumor prolıferation in bladder cancer Int J Cancer 57 508-514, 1994 
188 Saxena A, Clark WC, Robertson JT, Ikejiri B, Oldfield EH, Ali IU. Evidence for the involvement of a potential second tumor suppressor gene on chromosome 17 distinct from p53 in malignant astrocytomas [published erratum appears in Cancer Res 1993 Mar 15; 53(6):1472]. Cancer Res 52: 6716-6721, 1992.

189. Schalken JA, Bussemakers MJG Differential hybridization analysis as a tool to study prostatic cancer metastasis. In: Molecular and Cellular Bıology of prostate cancer. Plenum Press, New York, 345-354, 1991.

190 Schapers RF, Ploem Zaaijer JJ, Pauwels RP, Smeets AW, van den Brandt PA, Tanke HJ, Bosman FT Image cytometric DNA analysis in transitional cell carcinoma of the bladder. Cancer 72 . $182-189,1993$.

19l. Schuuring E, Verhoeven E, Mooi WJ, Michalıdes RJ. Identification and cloning of two overexpressed genes, U21B31/PRAD1 and EMS1, within the amplıfied chromosome $11 \mathrm{lq} 13$ region in human carcinomas. Oncogene 7 355-361, 1992.

192 Schwartz CE, Johnson JP, Holycross B, Mandeville TM, Sears TS, Graul EA, Carey JC, Schroer RJ, Phelan MC, Szollar J, et al. Detection of submicroscopic deletions in band 17p13 in patıents with the Miller-Dieker syndrome Am J Hum Genet 43. 597-604, 1988

193. Serrano M, Hannon GJ, Beach D A new regulatory motif in cell-cycle control causing specific inhibition of cyclin D/CDK4 [see comments]. Nature 366. 704-707, 1993.

194 Serth J, Kuczyk MA, Bokemeyer C, Hervatin C, Nafe R, Tan HK, Jonas U. p53 immunohistochemistry as an independent prognostic factor for superficial transitional cell carcinoma of the bladder BrJ Cancer 71 201-205, 1995.

195 Seto E, Usheva A, Zambetti GP, Momand J, Horikoshi N, Weinmann R, Levine AJ, Shenk T Wild-type p53 binds to the TATA-bindıng protein and represses transcription. Proc Natl Acad Scl US A 89: 12028-12032, 1992.

196 Sherman AB, Koss LG, Adams SE. Interobserver and intraobserver differences in the diagnosis of urothelial cells. Comparison with classification by computer. Anal Quant Cytol 6: 112-120, 1984.

197. Shipman R, Schraml P, Colombi M, Raefle G, Ludwig CU Loss of heterozygosity on chromosome 11 p13 in primary bladder carcinoma. Hum Genet 91: 455-458, 1993

198 Shivji MK, Grey SJ, Strausfeld UP, Wood RD, Blow JJ. Cipl inhibits DNA replication but not PCNA-dependent nucleotide excisıon-repair. Curr Bıol 4: 1062-1068, 1994.

199 Sidransky D, Von Eschenbach A, Tsai YC, Jones P, Summerhayes I, Marshall F, Paul M, Green P, Hamilton SR, Frost $P$, et al. Identification of p53 gene mutations in bladder cancers and urine samples Scrence 252: 706-709, 1991.

200. Sidransky D, Frost P, Von Eschenbach A, Oyasu R, Preisinger AC, Vogelsteın B. Clonal orıgın bladder cancer [see comments]. N Engl J Med 326: 737-740, 1992.

201 Slebos RJ, Lee MH, Plunkett BS, Kessis TD, Williams BO, Jacks T, Hedrick L, Kastan MB, Cho KR. p53-dependent Gl arrest involves pRB-related proteins and is disrupted by the human papillomavirus 16 E7 oncoproten Proc Natl Acad Scr US A 91: 5320-5324, 1994. 
202 Smeets W, Pauwels R, Laarakkers L, Debruyne F, Geraedts J Chromosomal analysis of bladder cancer III Nonrandom alteratıons Cancer Genet Cytogenet 29 29-41, 1987

203 Smith ML, Chen IT, Zhan Q, Bae I, Chen CY, Gilmer TM, Kastan MB, O'Connor PM, Fomace AJJ Interaction of the p53-regulated protein Gadd45 with proliferatıng cell nuclear antigen [see comments] Science 266 1376-1380, 1994

204 Soloway MS Intravesıcal therapy for bladder cancer Urol Clın North Am 15 661-669, 1988

205 Soussı T, Caron de Fromentel C, May P Structural aspects of the p53 protein in relation to gene evolution Oncogene 5 945-952, 1990

206 Sparkes RS, Sparkes MC, Wilson MG, Towner JW, Benedict W, Murphree AL, Yunıs JJ Regınal assignment of genes for human esterase D and retınoblastoma to chromosome band 13q14 Sclence 208 1042-1044, 1980

207 Spruck CH, Ohneseıt PF, Gonzalez Zulueta M, Esrıg D, Miyao N, Tsaı YC, Lemer SP, Schmutte C, Yang AS, Cote R, et al Two molecular pathways to transitıonal cell carcinoma of the bladder Cancer Res 54 784-788, 1994

208 Steeg PS, Bevilacqua G, Kopper L, Thorgeırsson UP, Talmadge JE, Lıotta LA, Sobel ME Evidence for a novel gene associated with low tumor metastatic potential $J$ Natl Cancer Inst 80 200-204, 1988

209 Takahashı R, Hashımoto T, Xu HJ, Hu SX, Matsuı T, Mıkı T, Bıgo Marshall H, Aaronson SA, Benedict WF The retınoblastoma gene functions as a growth and tumor suppressor in human bladder carcınoma cells Proc Natl Acad Scı USA 88 5257-5261, 1991

210 Takeıchı M Cadherın cell adhesıon receptors as a morphogenetıc regulator Science 251 1451-1455, 1991

211 Tamımı Y, van der Poel HG, Denyn MM, Umbas R, Karthaus HF, Debruyne FM, Schalken JA Increased expression of high mobility group proteın $I(Y)$ in high grade prostatic cancer determıned by in situ hybridization Cancer Res 53 5512-5516, 1993

212 Theodorescu D, Comıl I, Sheehan C, Man MS, Kerbel RS Ha-ras induction of the invasıve phenotype results in up-regulation of epidermal growth factor receptors and altered responsiveness to epidermal growth factor in human papillary transitional cell carcinoma cells Cancer Res 51 4486-4491, 1991

213 Thomas DJ, Robınson MC, Charlton R, Wılkınson S, Shenton BK, Neal DE PS3 expression, ploidy and progression in pT1 transitıonal cell carcınoma of the bladder Br J Urol 73 533-537. 1994

214 Thompson AM, Anderson TJ, Condie A, Prosser J, Chetty U, Carter DC, Evans HJ, Steel CM p53 allele losses, mutations and expression in breast cancer and their relationship to clinico-pathological parameters Int $J$ Cancer 50 528-532, 1992

215 Thompson IM, FAir WR The epıdemılogy of bladder cancer AUA Update Ser $8210-215,1989$

216 Thut CJ, Chen JL, Klemm R, Tjıan R p53 transcriptional actıvation mediated by coactivators TAFII40 and TAFII60 Scrence 267 100-104, 1995 
217 Tortı SV, Kwak EL, Mıller SC, Mıller LL, Rıngold GM, Myambo KB, Young AP, Tortı FM The molecular cloning and characterization of murıne ferritın heavy chain, a tumor necrosis factor-inducible gene $J$ Biol Chem 263 12638-12644, 1988

218 Travis GH, Sutcliffe JG Phenol emulsion-enhanced DNA-driven subtractive cDNA cloning Isolation of low-abundance monkey cortex-specific mRNAs Proc Natl Acad Sct USA 85 16961700,1988

219 Tribukait B, Gustafson H, Espostı PL The significance of ploidy and proliferation in the clinical and biological evaluation of bladder tumours a study of 100 untreated cases $\mathrm{Br} J$ Urol 54 130-135, 1982

220 Truant R, Xıao H, Ingles CJ, Greenblatt J Direct interaction between the transcriptional actıvatıon domain of human p53 and the TATA box-bindıng proteın J Bıol Chem 268 2284-2287, 1993

221 Tsal YC, Nıchols PW, Hitı AL, Willıams Z, Skınner DG, Jones PA Allelıc losses of chromosomes 9, 11, and 17 in human bladder cancer Cancer Res 50 44-47, 1990

222 Tsujı Y, Miller LL, Mıller SC, Tortı SV, Tortı FM Tumor necrosıs factor-alpha and interleukın I-alpha regulate transferrın receptor in human diploid fibroblasts Relationship to the induction of ferritın heavy chain $J$ Biol Chem 266 7257-7261, 1991

223 Tsujı Y, Kwak E, Saıka T, Tortı SV, Tortı FM Preferential repression of the $\mathbf{H}$ subunit of ferritın by adenovirus ElA in NIH-3T3 mouse fibroblasts.J Bıol Chem 268 7270-7275, 1993

224 Tyrkus M, Powell I, Fakr W Cytogenetic studies of carcınoma in situ of the bladder prognostıc implications J Urol 148 44-46, 1992

225 Uchıda T, Wada C, Ishıda H, Wang C, Egawa S, Yokoyama E, Kameya T, Koshıba K p53 mutations and prognosis in bladder tumors $J$ Urol 153 1097-1104, 1995

226 UICC (International Union Against Cancer) TNM classıfication of malignant tumours $4^{\text {th }}$ ed Berlin Springer-Verlag, 1987

227 Underwood M, Bartlett J, Reeves J, Gardıner DS, Scott R, Cooke T C-erbB-2 gene amplıficatıon a molecular marker in recurrent bladder turnors? Cancer Res 55 2422-2430, 1995

228 Van der Poel HG, Oosterhof GO, Schaafsma HE, Wiersma van Tılburg A, Debruyne FM, Schalken JA Karyometry of bladder washings for the follow up of patients with transitional cell carcınoma of the bladder Prog Clın Bıol Res 378 9-18, 1992

229 Van Meyel DJ, Ramsay DA, Casson AG, Keeney M, Chambers AF, Carncross JG p53 mutation, expression, and DNA ploidy in evolving gliomas evidence for two pathways of progression $J$ Natl Cancer Inst 86 1011-1017, 1994

230 Van Moorselaar RJ, Ichıkawa T, Schaafsma HE, Jap PH, Isaacs JT, van Stratum P, Ramaekers FC, Debruyne FM, Schalken JA The rat bladder tumor model system RBT resembles phenotypically and cytogenetıcally human superficial transitıonal cell carcınoma Urol Res 21 413-421, 1993

231 Vannı R, Scarpa RM Nonrandom chromosomal changes in transitional cell carcinoma of the bladder [letter] Cancer Res 464873,1986 
232. Vaughn CB, Weinstein R, Bond B, Rıce R, Vaughn RW, McKendrick A, Ayad G, Rockwel! MA, Rocchio R. Ferritin content in human cancerous and noncancerous colonic tissue. Cancer Invest 5: 7-10, 1987.

233. Vet JA, Bringuier PP, Poddighe PJ, Karthaus HF, Debruyne FM, Schalken JA. p53 mutations have no additional prognostic value over stage in bladder cancer Br J Cancer 70: 496-500, 1994

234. Vet JAM, Brinhuier PP, Schaafsma HE, Witjes JA, Debruyne FM, Schalken JA Comparison of p53 protein overexpression with p53 mutation in bladder cancer: clinical and bilogical aspects. Lab Invest 73: 837-843, 1995.

235. Vleminckx K, Vakaet L,Jr., Mareel M, Fiers W, van Roy F. Genetic manipulation of E-cadherin expression by epithelial tumor cells reveals an invasion suppressor role Cell 66 107-119, 1991.

236. Vogelstein B, Fearon ER, Kern SE, Hamilton SR, Preisinger AC, Nakamura Y, White R. Allelotype of colorectal carcinomas. Science 244. 207-211, 1989.

237. Vogelstein B. Cancer. A deadly inheritance [news; comment]. Nature 348: 681-682, 1990.

238 Vogelstein B, Kinzler KW p53 function and dysfunction. Cell 70: 523-526, 1992.

239. Voorter C, Joos S, Bringuer PP, Vallinga M, Poddighe P, Schalken J, du Manoir S, Ramaekers F, Lichter P, Hopman A. Detection of chromosomal imbalances in transitional cell carcinoma of the bladder by comparative genomic hybrıdization. Am J Pathol 146: 1341-1354, 1995.

240. Waga S, Hannon GJ, Beach D, Stillman B. The p2l inhibitor of cyclin-dependent kinases controls DNA replication by interaction with PCNA [see comments]. Nature 369: 574-578, 1994.

241 Wang XW, Forrester K, Yeh H, Feitelson MA, Gu JR, Harris CC Hepatitis B virus X proteın inhibits p53 sequence-specific DNA bindıng, transcriptional activity, and association with transcription factor ERCC3. Proc Natl Acad Sct US A 91: 2230-2234, 1994.

242 Warbrick E, Lane DP, Glover DM, Cox LS A small peptide inhibitor of DNA replication defines the site of interaction between the cyclin-dependent kinase inhibitor p21WAF1 and proliferating cell nuclear antigen Curr Brol 5: 275-282, 1995.

243 Werness BA, Levine AJ, Howley PM. Association of human papillomavirus types 16 and 18 E6 proteins with p53. Science 248: 76-79, 1990.

244 Whyte P, Buchkovich KJ, Horowitz JM, Friend SH, Raybuck M, Weinberg RA, Harlow E Association between an oncogene and an anti-oncogene: the adenovirus ElA proteins bind to the retinoblastoma gene product. Nature 334: 124-129, 1988

245. Williamson MP, Elder PA, Knowles MA. The spectrum of TP53 mutations in bladder carcinoma. Genes Chromosom Cancer 9: 108-118, 1994.

246. Worwood M, Brook JD, Cragg SJ, Hellkuhl B, Jones BM, Perera P, Roberts SH, Shaw DJ Assignment of human ferritin genes to chromosomes 11 and $19 q 13.3----19 q t e r$. Hum Genet 69 371-374, 1985

247. Wu JK, Ye Z, Darras BT. Sensitivity of single-strand conformation polymorphısm (SSCP) analysis in detecting p53 point mutatıons in tumors with mixed cell populations. Am J Hum Genet 52: 1273-1275, 1993. 
248 Wu SQ, Storer BE, Bookland EA, Klıngelhutz AJ, Gılchrıst KW, Meısner LF, Oyasu R, Reznıkoff CA Nonrandom chromosome losses in stepwise neoplastıc transformation in vitro of human uroepithelial cells Cancer Res 51 3323-3326, 1991

249 Wynford Thomas D P53 in tumour pathology can we trust immunocytochemistry? [editorial] $J$ Pathol 166 329-330, 1992

250 Xiong Y, Zhang H, Beach D D type cyclins associate with multiple protein kinases and the DNA replication and repair factor PCNA Cell 71 505-514, 1992

251 Xu HJ, Caıms P, Hu SX, Knowles MA, Benedict WF Loss of RB protein expression in primary bladder cancer correlates with loss of heterozygosity at the RB locus and tumor progression Int $J$ Cancer 53 781-784, 1993

252 Yamamoto T, Ikawa S, Akıyama T, Semba K, Nomura N, Mıyajıma N, Saıto T, Toyoshıma K Similarity of proteın encoded by the human c-erb-B-2 gene to epidermal growth factor receptor Nature 319 230-234, 1986

253 Yin Y, Tainsky MA, Bischoff FZ, Strong LC, Wahl GM Wild-type p53 restores cell cycle control and inhibits gene amplification in cells with mutant p53 alleles Cell 70 937-948, 1992

254 Zambettı GP, Levine AJ A comparison of the biological actıvitıes of wild-type and mutant p53 FASEB $J 7$ 855-865, 1993

255 Zeın T, Wajsman Z, Englander LS, Gamarra M, Lopez C, Huben RP, Pontes JE Evaluation of bladder washings and urine cytology in the diagnosis of bladder cancer and its correlation with selected biopsies of the bladder mucosa J Urol $132670-671,1984$

256 Zhau HE, Zhang X, von Eschenbach AC, Scorsone K, Babaian RJ, Ro JY, Hung MC Amplification and expression of the c-erb B-2/neu proto-oncogene in human bladder cancer $\mathrm{Mol}$ Carcinog 3 254-257, 1990 


\section{Samenvatting en algemene discussie}

Een belangrıjk probleem bij de klinısche behandelıng van transitioneel cel carcinoma van de blaas (TCC), is de identificatie van patienten met een risico voor progressie van hun ziekte Naast de "klassieke" histopathologische diagnose en klınısche parameters is er dringend behoefte aan nieuwe markers, die patienten met een risico voor tumorprogressie kunnen identificeren De laatste jaren heeft de vooruitgang in de moleculaire benaderıng van tumorbiologie geresulteerd in een beter begrip van kankergenetica en nieuwe potentiele prognostısche markers Dit proefschrift beschrift twee benaderıngen om moleculaire prognostısche factoren te evalueren (1) de prognostische waarde van het bekende tumorsuppressor gen p53 en z1jn belang als diagnostısch hulpmiddel, (11) het gebruk van de differentiele hybridisatıe analyse als een methode om nieuwe moleculare prognostische factoren te identıficeren

Op genetısch nivo kunnen p53 veranderıngen direct geıdentıficeerd worden door mutaties in het p53 gen te detecteren, gebrulk makend van de Polymerase Chain Reaction-Single Strand Conformation Polymorphism (PCR-SSCP) analyse, of indirect door detectie van overexpressie van het p53 eıwit, gebruik makend van immunohıstochemie (IHC) Om hun betrouwbaarheid te bepalen zijn deze twee methoden onderlıng vergeleken in hoofdstuk 2 Ondanks de goede correlatıe $(p<002)$ tussen p53 mutatie, bepaald door SSCP analyse, en p53 overexpressie, bepaald door IHC, zıjn in een aanzienlıjk aantal tumoren verschillen gevonden Twee van de acht tumoren met een p53 mutatie (SSCP) vertoonden in het geheel geen p53 ımmunoreactıviteıt, waarschınlıjk veroorzaakt door verlies van het kern localısatıe sıgnaal Naast deze "onjuıst negatıeven", is p53 overexpressıe waargenomen in 23\% van de tumoren waarbij geen p53 mutatie aangetoond kon worden door SSCP analyse Daarom is er, ondanks de sterke correlatie tussen p53 mutatie en p53 overexpressie, geen direct causaal verband tussen mutatie en overexpressie Blıkbaar kunnen behalve mutaties ook andere gebeurtenıssen stabiliteıt van p53 veroorzaken Aanvullend onderzoek is nodig om deze gebeurtenissen te karakteriseren en de mechanismen te begrıpen waardoor deze overexpressıe, zonder een gelıjktıjdige mutatıe, veranderıng ıan p53 functie weerspiegelt en vervolgens een ander phenotype veroorzaakt in kankercellen 
Klinische parameters zijn vergeleken met p53 overexpressie (IHC) en p53 mutatie (PCR-SSCP) (Hoofdstuk 2 en 3). Een significante correlatie tussen p53 verandering en zowel graad als stadium is waargenomen $(p<0.05$ vs IHC en $p<0.001$ vs SSCP, respectievelijk). Bovendien is p53 verandering een slechte prognostische factor voor de hele groep van blaaskanker patiënten $(p<0.01$ vs IHC en $p<0.001$ vs SSCP, respectievelijk). Voor invasieve tumoren is er geen associatie gevonden tussen p53 verandering en een verkorte overlevingsperiode. De immunohistochemische resultaten voor invasieve tumoren zijn in tegenspraak met andere studies. Verschillen in de behandeling van patiënten, het antilichaam, methode en scoringssysteem dat gebruikt is, zouden deze discrepanties kunnen verklaren. Echter, een recente studie heeft laten zien dat voor de groep van spier-invasieve tumoren, p53 overexpressie slechts significant tumorprogressie voorspelt, wanneer de ziekte zich beperkt tot de blaas ( $\mathrm{pT} \leq 3 \mathrm{a})$. Indien de ziekte meer uitgebreid is $(\mathrm{pT} \geq 3 \mathrm{~b}$ ), heeft $\mathrm{p} 53$ overexpressie geen additionele prognostische waarde. Vanwege het relatief kleine aantal invasieve tumoren in onze studie hebben we deze twee groepen niet kunnen vergelijken. In oppervlakkig TCC is er een verschuiving waargenomen naar een kortere overlevingsperiode voor de patienten met p53 overexpressie. Er zijn geen p 53 mutaties waargenomen in deze groep van oppervlakkige tumoren. Dit verschil benadrukt opnieuw het onderscheid tussen p53 immunohistochemie en p53 mutatie analyse.

In hoofdstuk 3 is ook de associatie tussen p53 mutaties en frequentie van allelisch verlies, als een mogelijke indicator voor genetische instabiliteit, onderzocht. $\mathrm{Er}$ is een hoge frequentie van allelisch verlies gevonden in tumoren met een p53 mutatie, hetgeen wijst op een correlatie met genetische instabiliteit. Dit kan worden verklaard door een veranderd G1-S cel cyclus controlepunt, als gevolg van het verlies van de wild type p53 functie.

Het is zeer belangrijk om te definiëren of en wanneer p53 mutaties optreden tijdens tumorprogressie van oppervlakkige (Ta) tumoren naar lamina propria invasieve ( $\mathrm{Tl}$ ) tumoren en spier-invasieve (T2-T4) tumoren. Om de waarde van p53 mutaties te bepalen voor het voorspellen van progressie van oppervlakkig TCC zijn opeenvolgende blaasspoelingen van oppervlakkige TCC patiënten met een hoog risico (geïdentificeerd door kwantitatieve karyometrische analyse) onderzocht (Hoofdstuk 4). We hebben gekozen voor directe analyse van mutaties vanwege het meer objectieve karakter van deze methode vergeleken met IHC. Omdat cellen van de gehele blaas worden geoogst. 
hebben blaasspoelingen het voordeel ten opzichte van histologische biopsies dat ze de algemene status van de blaas mucosa weergeven. Bovendien is dit een eenvoudige poliklinische procedure zodat patiënten vaker kunnen worden gecontroleerd. Zes van de 13 patiënten met klinische progressie (naar $\mathrm{pT} \geq 2$ ) vertoonden een $\mathrm{p} 53$ mutatie in één of meer van hun blaasspoelingen voordat progressie optrad. In de controle groep (geen progressie) vertoonde maar één van de 13 patiënten een p53 mutatie. In patiënten met een hoog risico, geïdentificeerd door kwantitieve karyometrische analyse, heeft het verschijnen van een p53 mutatie een positief voorspellende waarde voor progressie naar invasieve ziekte van $86 \%$. De lage negatief voorspellende waarde (63\%) impliceert dat, ondanks het feit dat een p53 mutatie de kwaardaardige potentie van een tumor aangeeft, de afwezigheid van een p53 mutatie geen garantie is voor een goede prognose. Omdat p53 mutaties zijn gevonden in samples voor gedocumenteerde progressie, kan hun aanwezigheid patiënten identificeren die een verandering in hun behandeling nodig hebben om mogelijk progressie naar invasieve ziekte te voorkomen. De klinische bruikbaarheid van p53 mutatie analyse als diagnostisch hulpmiddel zal nu bepaald moeten worden in een grote prospectieve studie.

Hoofdstuk 5 beschrijft de vergelijkende p53 mutatie analyse van blaasspoelingen en hun vergezellende tumoren om de werkelijke waarde van blaasspoelingen te bepalen voor het weergeven van de p53 status van het histologische materiaal. De p53 status van de blaasspoelingen en het histologische materiaal vertonen een significante correlatie, wanneer deze vergeleken werden voor alle samples van een enkele patient $(p<0.05$, Fischer exact test, two tail). Samenvattend, in twee patienten ( 2 van de 15 ) is de mutatie die aanwezig was in de tumoren niet gedetecteerd in de blaasspoelingen. In een derde patient is de mutatie in de blaasspoeling niet gedetecteerd in het histologische materiaal. Dit tegenstrijdige resultaat tussen de p53 status van de blaasspoelingen en het histologisch materiaal kan gedeeltelijk worden verklaard door de architectuur van de tumoren. Deze studie laat zien dat de analyse van p53 mutaties in opeenvolgende blaasspoelingen van een patient in het algemeen de p53 status van de vergezellende tumor weergeeft. Zoals reeds vermeld is het wassen van de blaas een eenvoudige poliklinische procedure waardoor controle van patiënten op een meer frequente basis mogelijk is. Dit zou kunnen leiden tot een verhoogde detectie van TCC patienten met een hoog risico voor progressie waardoor mogelijk deze progressie naar invasieve ziekte voorkomen zou kunnen worden. 
Naast de studie van de prognostische waarde van het bekende tumorsuppressor gen p53, hebben we gebruik gemaakt van differentiële hybridisatie analyse om nieuwe moleculaire prognostische markers te identificeren die geassocieerd zijn met progressie van oppervlakkig blaaskanker (Hoofdstuk 6). Primair tumormateriaal is meestal samengesteld uit subpopulaties met verschillende kwaadaardige potentie en is daarom niet geschikt om TCC progressie markers te identificeren. In deze studie is een rat blaas tumor model systeem gebruikt, dat phenotypisch en cytogenetisch lijkt op humaan oppervlakkig TCC. De mRNA populaties van laag en hoog metastaserende lijnen zijn vergeleken. Er is overexpressie van ferritine Heavy $(H)$ chain waargenomen in de tumorlijn met de laagst metastaserende capaciteit en beter gedifferentieerd phenotype. Ferritine $H$ vormt samen met de ferritine Light subunit het eiwit ferritine, dat zorgt voor de opslag van ijzer. Er is een relatie tussen ferritine en kanker voorgesteld en sommige neoplastische cellen vertonen een opmerkelijk veranderde samenstelling in ferritine subunits, vergeleken met hun normale tegenhangers. De overexpressie van ferritine $\mathrm{H}$ in de beter gedifferentieerde tumorlijn is een bevestiging van de waargenomen associatie tussen ferritine $\mathrm{H}$ en een aantal differentiatie processen. De waargenomen lagere expressie van ferritine $\mathrm{H}$ in de meer kwaardaardige tumorlijn stemt overeen met de waarneming dat tijdens oncogene transformatie, het adenovirus E1A oncogen specifiek de expressie van ferritine $\mathrm{H}$ remt. Omdat we gebruik hebben gemaakt van een rat blaas tumor model systeem voor de differentiële hybridisatie experimenten, zal de waarde van de differentiële expressie van ferritine $\mathrm{H}$ als een prognostische marker in het humane systeem nog opgehelderd moeten worden.

De studies die in dit proefschift beschreven zijn, benadrukken dat veranderingen in het tumorsuppressor gen p53 belangrijk zijn voor het klinische gedrag van blaastumoren. Ondanks de goede overall overeenkomst tussen p53 gen mutatie en p53 eiwit overexpressie in relatie tot graad, stadium en overlevingsperiode, is er geen causaal verband tussen mutatie en overexpressie. In de groep van oppervlakkig TCC patiënten met een hoog risico, geïdentificeerd door middel van kwantitatieve karyometrische analyse, lijkt de verschijning van een p 53 mutatie geanalyseerd in blaasspoelingen van waarde te zijn als een extra marker om progressie naar invasieve ziekte te voorspellen. Ondanks deze veelbelovende resultaten is het duidelijk dat er meer prognostische markers nodig zijn om niet alleen de positief voorspellende waarde, maar vooral de 
negatief voorspellende waarde van deze screenings procedure te verhogen. De differential display techniek zou bruikbaar kunnen zijn als een middel om nieuwe prognostische markers te identificeren, gesteld dat de te vergelijken mRNA populaties zeer precies worden gedefinieerd. Voor het panel van prognostische markers zijn op dit moment de Epidermal Growth Factor Receptor en E-cadherin goede kandidaten. Samen met de "klassieke" histopathologische diagnose en klinische parameters, zou dit panel van prognostische markers geëvalueerd moeten worden in een grote prospectieve studie met goed gedefinieerde patiënten populaties en gestandaardiseerde technische procedures, zodat de preciese klinische relevantie bepaald kan worden. 


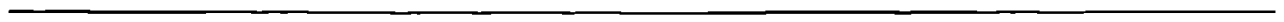




\section{Dankwoord}

Aan het einde van dit proefschrift wil ik benadrukken dat tijdens een promotieonderzoek de hulp van, en de samenwerking met, andere mensen onmisbaar is. Naar mijn mening is samenwerken de basis voor goed onderzoek en datgene waardoor het onderzoek leuk blijft. Allen die op welke wijze dan ook betrokken zijn geweest bij de totstandkoming van dit proefschrift wil ik hiervoor hartelijk danken. Het leven is meer dan een promotieonderzoek alleen, al leek het er de laatste maand soms niet op.

Mijn familie, vrienden en met name Arno wil ik bedanken voor "het er zijn", dat veel meer inhoud dan op papier te beschrijven is. Heel duidelijk voor mij is het volgende : "Zonder vriendschap is het leven en ook dit proefschrift niets waard"

(vrij naar: Sine amicitia vitam esse nullam. Cicero, Laelius de amicitia dialogus, 23,86). 


\section{Curriculum vitae}

Jacqueline Vet werd geboren op 28 maart 1963 te Gendringen. In 1981 behaalde zij het Atheneum diploma aan het Isala College te Silvolde. In hetzelfde jaar werd begonnen met de opleiding tot analist, specialisatie botanie, aan de Rijks Hogere Agrarische School te Wageningen. Na de succesvolle afronding van deze studie in 1985, werkte zij van mei 1985 tot april 1991 als analiste op het Centraal Hematologisch Laboratorium van het Academisch Ziekenhuis Nijmegen. In 1986 werd begonnen met de studie Biologie aan de Katholieke Universiteit te Nijmegen en deze studie werd in 1988 in deeltijd voortgezet aan de Rijks Universiteit van Utrecht. In februari 1991 behaalde zij het doctoraal examen Biologie met als specialisaties Microbiologie en Haematologie. In april 1991 volgde een aanstelling als wetenschappelijk medewerkster op de afdeling Urologie van het Academisch Ziekenhuis Nijmegen waar werd gewerkt aan het onderzoek waarvan de resultaten in dit proefschrift beschreven staan. Sinds 1 maart 1996 is zij werkzaam als post-doctoral fellow op de afdeling Molecular Genetics van het Public Health Research Institute te New York. 

Het Ene is in alles

alles is in het Ene

Als je dit beseft

ben je niet langer bezorgd

over je tekortkomingen.

(Hsın Hsın Mıng, oude Chınese Zen-tekst) 




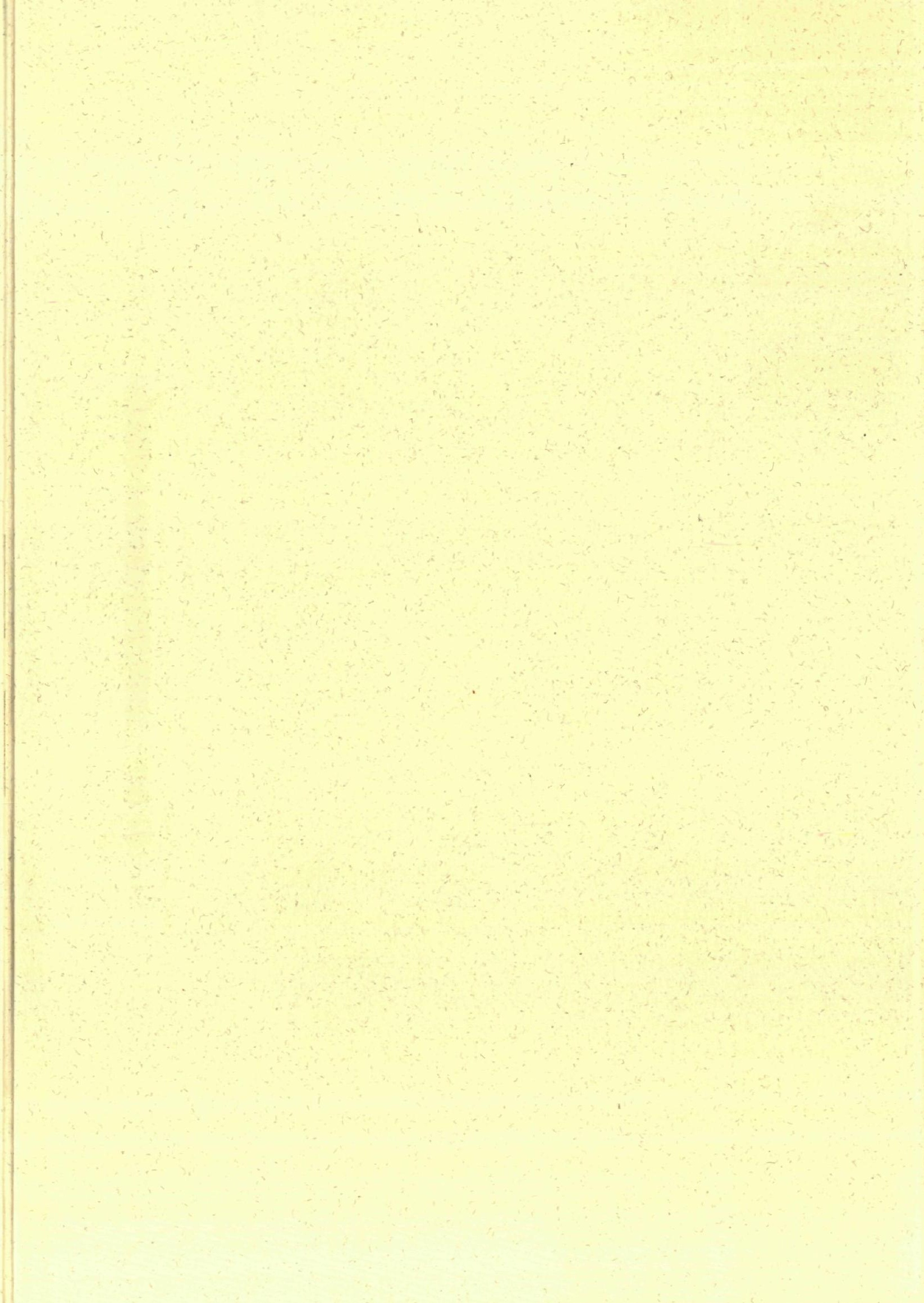

